\title{
HLW Tank Space Management, Final Report
}

by

\section{J. Sessions}

Westinghouse Savannah River Company

Savannah River Site

Aiken, South Carolina 29808

M. Miller

M. Mahoney, and L. Poe

G. Abell

R. Garrett

P. d'Entremont

J. Fowler

DOE Contract No. DE-AC09-96SR18500

This paper was prepared in connection with work done under the above contract number with the U. S.

Department of Energy. By acceptance of this paper, the publisher and/or recipient acknowledges the U. S. Government's right to retain a nonexclusive, royalty-free license in and to any copyright covering this paper, along with the right to reproduce and to authorize others to reproduce all or part of the copyrighted paper. 
Savannah River Site

High Level Waste Tank Space Management Team

Final Report (U)

WSRC-RP-99-00005

Revision: 0

August 26, 1999 
HLW Tank Space Management Team

Final Report

Approved By:

G. Abell, Systems Engineering Approved By:<smiles>C1CC2CC1C2</smiles>

R. Garrett, Safety \& Regulatory Engineering

Approved By: Gaul D.d'Bthemm P. d'Entremont, HLW Tank Farms Engineering.

Approved By:

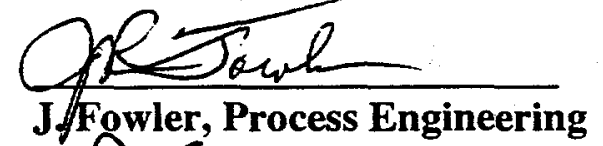

Approved By:

R. Fowler, Process Engineering

Approved By:

Approved By:

Approved By:

L. Poe, Public Berceptions of HLW

Approved By:

M. Miller, HLW Tank Space

Approved By:

R. Wilson, HLW Operations/

Maintenance

Managemant Tear Leader

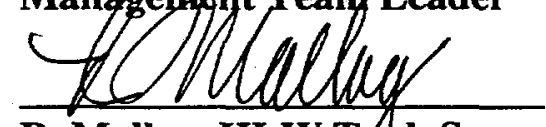

$$
8-26-99
$$

Date

$\frac{q-26-95}{\text { Date }}$

$\frac{8 / 26 / 99}{\text { Date }^{\prime}}$
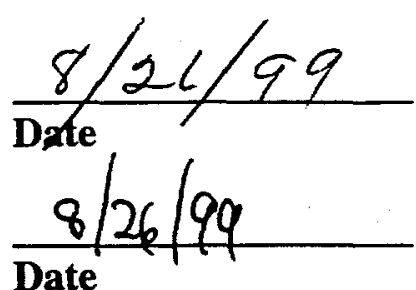

Date

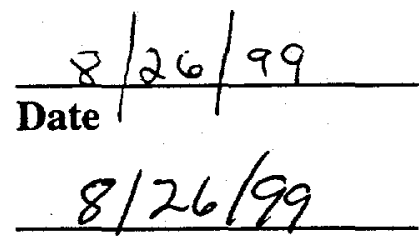

Date

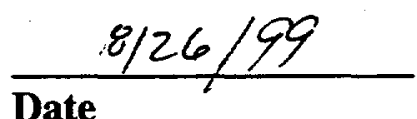

R. Malloy, HLW Tank Space Management Team Sponsor

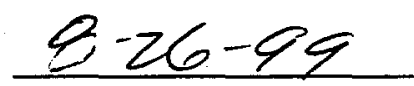

Date

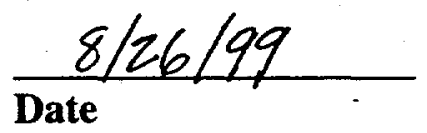




\section{DISCLAIMER}

This report was prepared as an account of work sponsored by an agency of the United States Government. Neither the United States Government nor any agency thereof, nor any of their employees, makes any warranty, express or implied, or assumes any legal liability or responsibility for the accuracy, completeness, or usefulness of any information, apparatus, product, or process disclosed, or represents that its use would not infringe privately owned rights. Reference herein to any specific commercial product, process, or service by trade name, trademark, manufacturer, or otherwise does not necessarily constitute or imply its endorsement, recommendation, or favoring by the United States Govermment or any agency thereof. The views and opinions of authors expressed herein do not necessarily state or reflect those of the United States Government or any agency thereof.

This report has been reproduced directly from the best available copy.

Available to DOE and DOE contractors from the Office of Scientific and Technical Information, P.O. Box 62, Oak Ridge, TN 37831; prices available from (615) 576-8401.

Available to the public from the National Technical Information Service, U.S. Department of Commerce, 5285 Port Royal Road, Springfield, VA 22161. 


\section{DISCLAIMER}

Portions of this document may be illegible in electronic image products. Images are produced from the best available original document. 
High Level Waste Tank Space

Management Team

Final Report
WSRC-RP-99-00005

Revision: 0

Page 4 of 135

\section{REVISION SUMMARY}

Rev. No. Rev. Date Affected Sections Description of Revision

0

$8 / 26 / 99$

All

Initial Issue 


\begin{abstract}
Based on a recommendation by the Westinghouse Savannah River Company (WSRC), the Department of Energy (DOE) has decided not to operate the existing In-Tank Precipitation (ITP) Process. Because ITP is not operating, the tank space management Strategy described in the current High Level Waste (HLW) System Plan (Rev. 9) ${ }^{1}$ is inadequate to simultaneously receive, store and process HLW. The HLW Tank Space Management Team (SM Team) was chartered to select and recommend a HLW Tank Space Management Strategy (Strategy) for the HLW Management Division of Westinghouse Savannah River Co. (WSRC) until an alternative salt disposition process is operational. Because the alternative salt disposition process will not be available to remove soluble radionuclides in HLW until 2009, the selected Strategy must assure that it safely receive and store HLW at least until 2009 while continuing to supply sludge slurry to the DWPF vitrification process.
\end{abstract}

The SM Team used the Systems Engineering (SE) process, which is described in this report to identify, evaluate and select a Strategy. Based on the results of this process, the SM Team recommends a Strategy consisting of the following actions:

- Continue to evaporate liquid waste, including the backlog waste that has not been concentrated as much as possible, throughout the period;

- Use Tank 49 for general HLW storage instead of assigning it to the ITP process;

- Install an evaporator in the DWPF salt cell to eliminate the current practice of returning DWPF aqueous byproduct waste ("DWPF Recycle") to the HLW Tank Farms;

- Return Tank 50 to HLW service in 2004 by installing a staging tank between ETF and Z Area for ETF bottoms, and operating Saltstone intermittently;

- When appropriate, implement ideas that gain small incremental volumes (less than $900 \mathrm{Kgal}$ ) that were identified by the SM Team as part of this work; and

- If necessary near the end of the period, incrementally reduce the minimum emergency space (presently set at $2600 \mathrm{Kgal}$ for the $\mathrm{F}$ and $\mathrm{H}$ Tank Farms) to the $\mathrm{AB}$ minimum requirement of $1300 \mathrm{Kgal}$.

In addition to these recommended actions, other tank farm practices and plans need to be continued, such as startup of the Replacement High Level Waste Evaporator (242-25H), maintenance of tank farm infrastructure including waste tanks and associated equipment and installation, and removal of waste from older tanks.

The information provided in this report supersedes previous SM Team approved documentation. 


\section{Table of Contents}

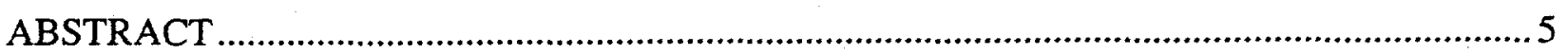

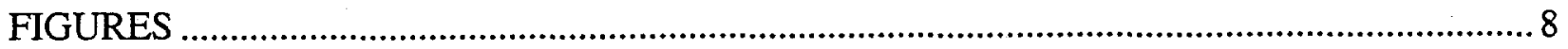

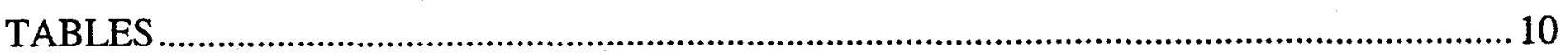

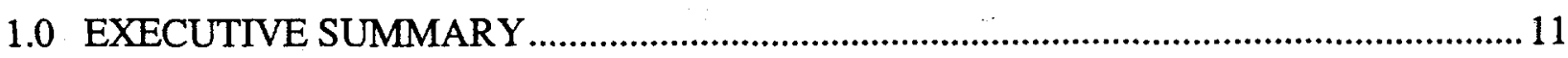

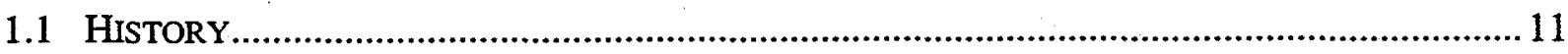

1.2 CHARTER

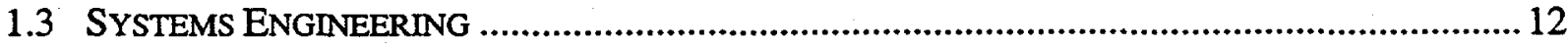

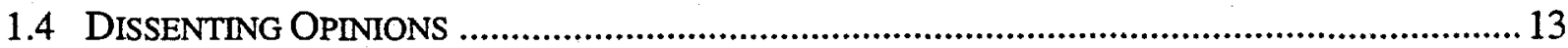

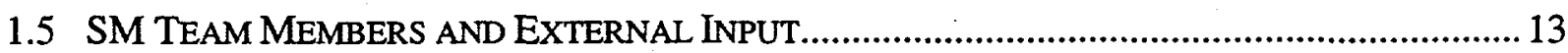

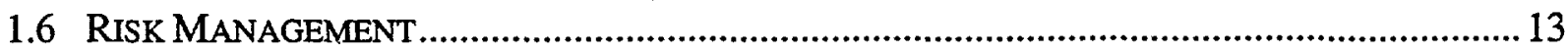

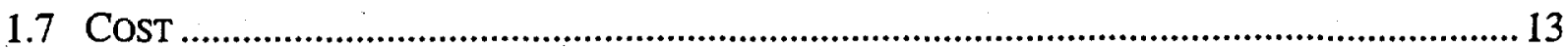

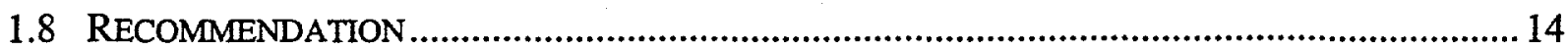

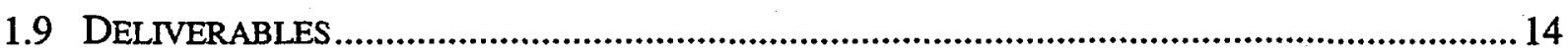

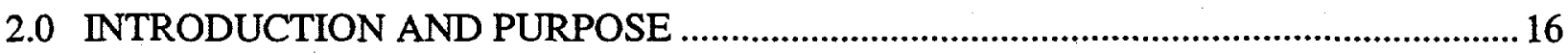

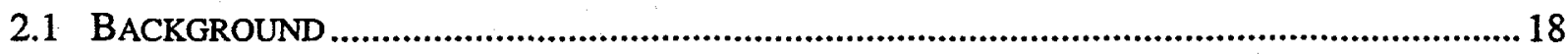

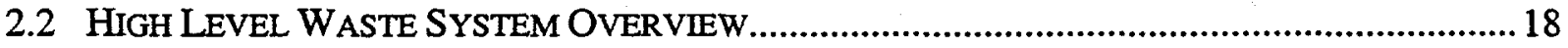

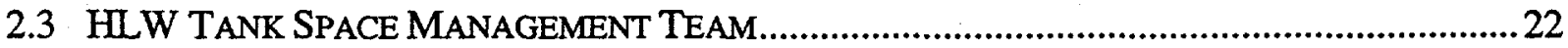

2.4 HLW TANK SPACE TEAM SUBJECT MATtER EXPERTS (SMES) .................................. 22

3.0 RECOMMENDED OVERALL STRATEGY ............................................................23

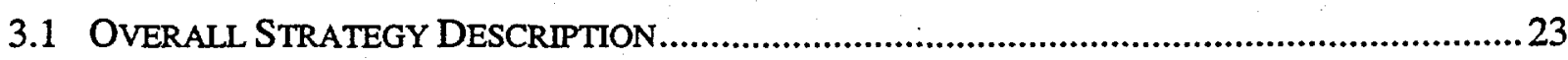

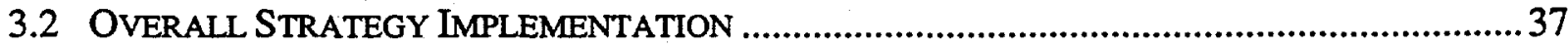

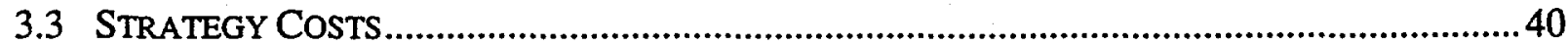

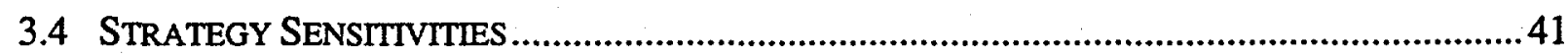

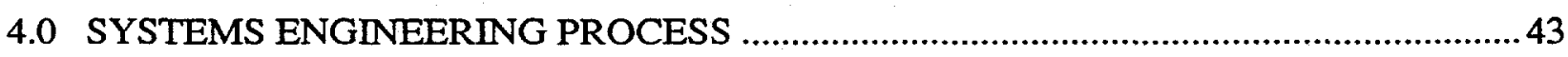

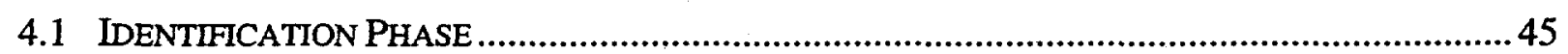

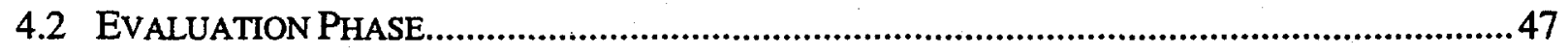

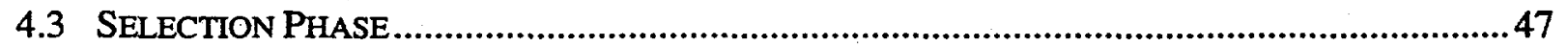

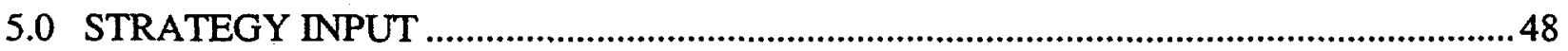

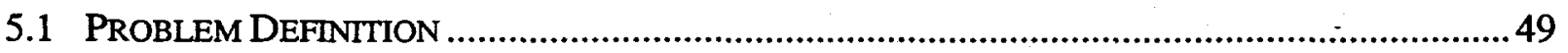

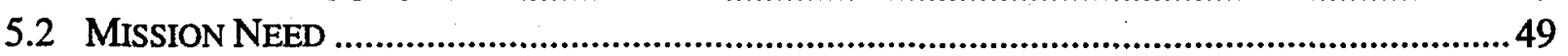

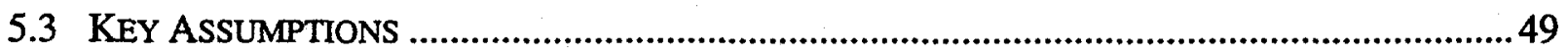

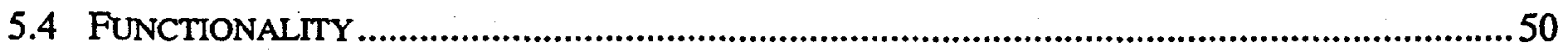

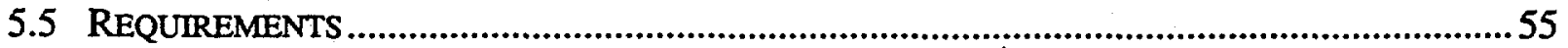

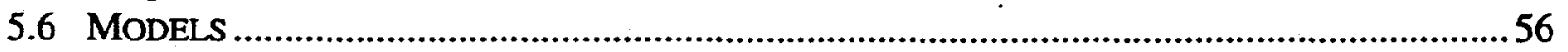

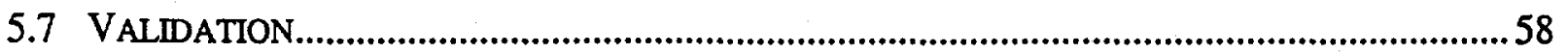




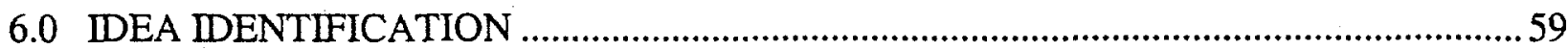

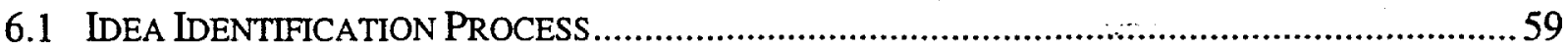

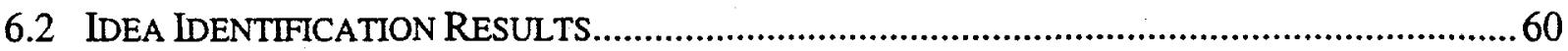

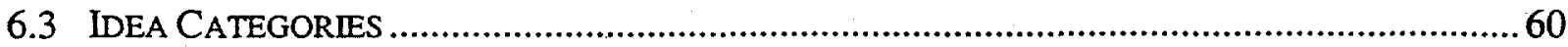

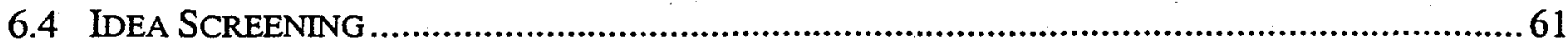

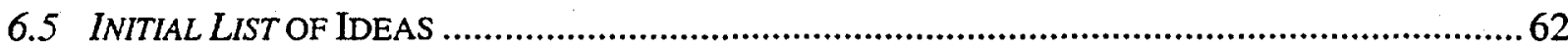

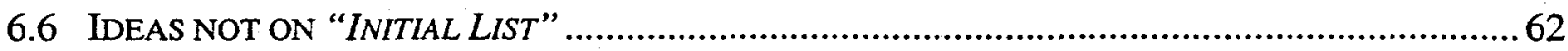

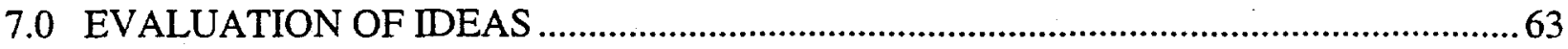

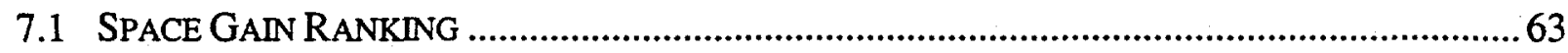

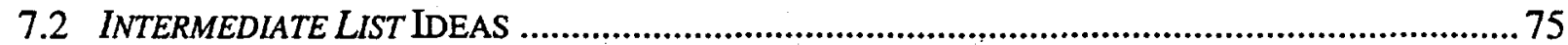

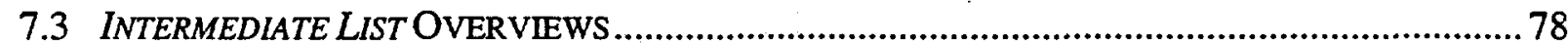

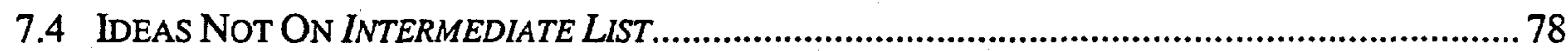

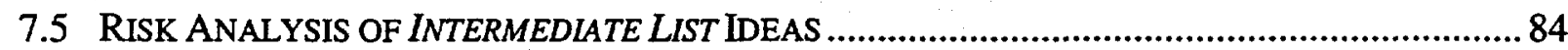

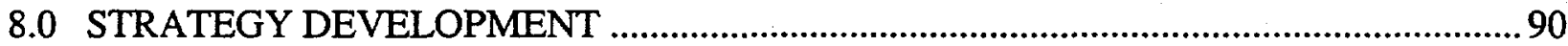

8.1 AVAIl ABLE SPACE BASELINE (ASB) PROFLE ..............................................................91

8.2 ELIMINATION OF COMBINATIONS WITH MUTUALL Y EXCLUSIVE IDEAS …….....................99

8.3 ELIMINATION OF COMBINATIONS OF IDEAS FAIIING TO MEET THE ASB PROFILE..............94

8.4 ELIMINATION OF DUPLICATE COMBINATIONS OF IDEAS ...................................................99

8.5 ELIMINATION OF SUPERFLUOUS COMBINATIONS OF IDEAS ...............................................99

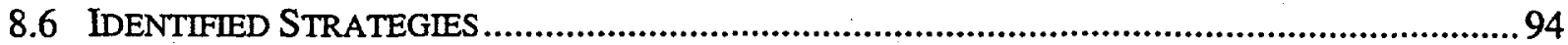

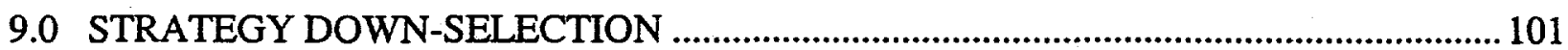

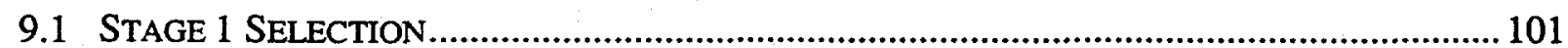

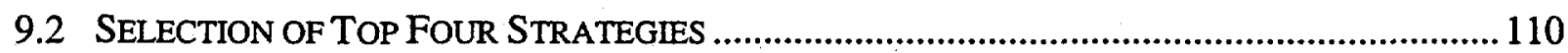

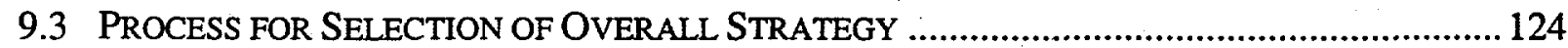

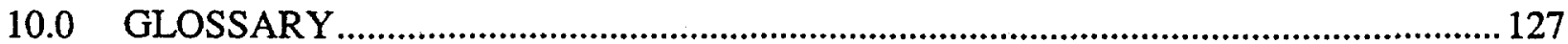

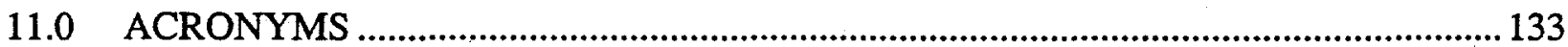

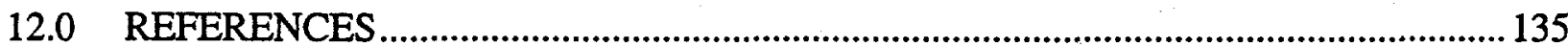




\section{Figures}

Figure 1-1: Documents Developed and/or Referenced in Final Report............................. 14

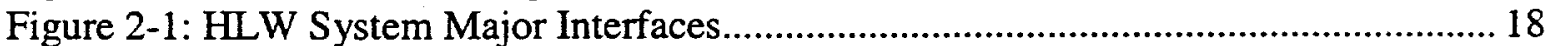

Figure 3-1: Comparison of IAS of Overall Strategy to IAS of Strategy S-17 and

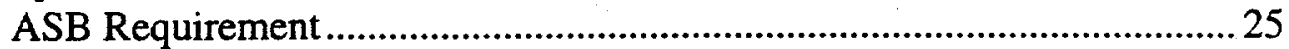

Figure 3-2: Impact of Overall Strategy on Proposed HLWD Funding (Basis:

Planning Case in Rev. 10 of the HLW System Plan $\left.{ }^{19}\right)$............................4 41

Figure 4-1: Hierarchical Relationship of the SEMP to Other SM Team Documents ......... 42

Figure 4-2: System Engineering Process for Strategy Selection....................................... 43

Figure 4-3: HLW Tank Space Management Strategy Development Business Model........ 45

Figure 5-1: Model Depicting Strategy Input Development ........................................... 47

Figure 5-2: HLW Tank Space Management Strategy Top Level Functional

Hierarchy

Figure 5-3: HLW Tank Space Management Strategy Functional Flow.............................. 50

Figure 5-4: Detailed Functional Hierarchy for HLW Tank Space Management

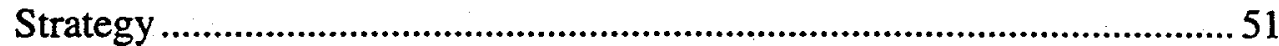

Figure 5-5: HLW Tank Space Management Strategy Administrative Solution Model....... 55

Figure 5-6: HLW Tank Space Management Strategy Universal Flow Sheet Model........... 56

Figure 7-1: TIAS Ranking Process for Initial List Ideas ...............................................63

Figure 7-2: Intermediate List versus Initial List Ranking Profile ................................... 74

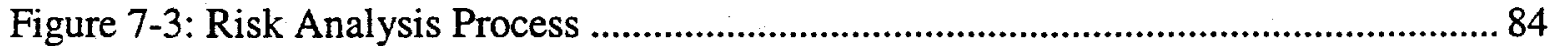

Figure 8-1: Model of Inputs, Controls, Supports and Outputs in Developing a List of

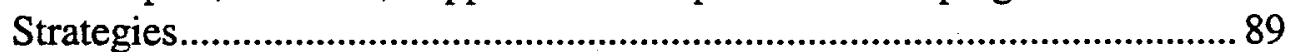

Figure 8-2: Cumulative Increase in Available Space Needed per ASB ${ }^{4}$............................. 90

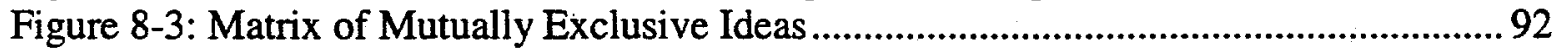

Figure 9-1: Multi-Stage Strategy Down-selection Process .............................................. 101

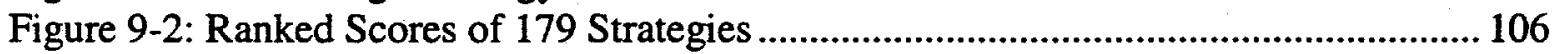

Figure 9-3: Effect of Ideas on Strategy Scores ......................................................... 109 


\section{Tables}

Table 3-1: Ideas Included in Overall Strategy ................................................................23

Table 3-2: Cumulative IAS for the Overall Strategy, K-gals...............................................24

Table 3-3: Cumulative IAS for Small Volume Gain Ideas, K-gals ........................................24

Table 3-4: Actions Required to Implement Strategy..........................................................37

Table 3-5: Strategy Life Cycle Costs (Cost in Millions of \$) ................................................39

Table 3-6: Idea Costs Between 2000 and 2009 (Costs in Millions) ....................................40

Table 7-1: Ranking Initial List Based on TIAS ............................................................64

Table 7-2: Summary of Intermediate List Ideas Based on TIAS Values (High to Low).........76

Table 7-3: "Small Volume Gains" Ideas..........................................................................78

Table 7-4: Risk Level (RL) Determination Matrix ...........................................................87

Table 8-1: HLW Tank Space Management Strategy List ................................................94

Table 9-1: HLW Tank Space Management Team Level 1 and Level 2 Evaluation Criteria, Assigned Weights, and Definitions ..........................................................103

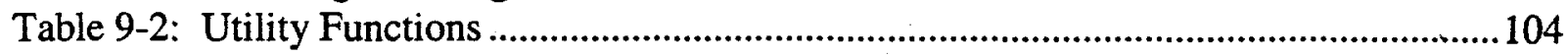

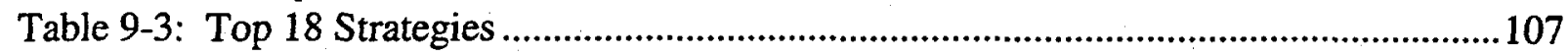

Table 9-4: Intermediate Ideas Eliminated from 179 Strategies During First Down-select .. 108

Table 9-5: Comparison of Functionally Equivalent Ideas .................................................120

Table 9-6: Down-Selection for Managing DWPF Recycle ...............................................121

Table 9-7: Down-Selection for Managing ETF Bottoms ..................................................122

Table 9-8: Emergency Space Down-Selection...............................................................122

Table 9-9: Strategies Remaining for the Short List ...................................................... 123 
High Level Waste Tank Space

WSRC-RP-99-00005

Management Team

Revision: 0

Final Report

Page 10 of 135

\subsection{Executive Summary}

This section provides a summary of the activities leading to the selection of the recommended HLW Tank Space Management Strategy altemative to the HLW System Plan (Revision 9). ${ }^{1}$ This summary describes the historical chronology, HLW Mission, the SM Team Charter, the selection process, and the recommended tank space management Strategy.

The contents of this Final Report supersede previously issued interim reports or documents produced by the SM Team.

\subsection{History}

The Savannah River Site (SRS) Site Treatment Plan (STP) and Federal Facilities Agreement (FFA) call for closing the HLW Tanks through vitrification of both the longlived and short-lived radioisotopes in the Defense Waste Processing Facility (DWPF) in preparation for transport to the national high level waste repository. The In-Tank Precipitation (ITP) facility was designed and constructed to separate the cesium isotopes from the non-radioactive salts so the decontaminated salts could be disposed in a grouted wasteform at the Saltstone facility at SRS, and limit the volume of HLW glass.

The ITP process was successfully piloted both on a moderate and full-scale basis with actual SRS waste in the 1980s. During the facility radioactive startup, higher than predicted benzene releases were observed. Additional laboratory and facility tests were initiated to further investigate process chemistry issues. On January 22, 1998, Westinghouse Savannah River Company (WSRC) informed DOE that ITP chemistry testing demonstrated that the present system configuration could not cost-effectively meet the safety and production requirements for the ITP facility and recommended that a study of alternatives to the current system configuration be conducted by a systems engineering team.

In February of 1998, the Assistant Secretary for Environmental Management approved a DOE-Savannah River (DOE-SR) plan of action to suspend startup-related activities and undertake a systems engineering study of alternatives to ITP and directed WSRC to perform an evaluation of alternatives to the current system configuration for HLW salt removal, treatment, and disposal.

The HLW Salt Disposition Systems Engineering Team was chartered to systematically develop and recommend an alternative method and/or technology for disposition of HLW Salt, their recommendation, was the Small Tank TPB Precipitation process, as the preferred alternative with Crystalline Silicotitanate Non-Elutable Ion Exchange as a backup technology. DOE reviewed the WSRC recommendation and requested that WSRC pursue studies to develop a Strategy and plan to maximize existing tank space flexibility until the alternative salt process is operating. 


\subsection{Charter}

On February 26, 1999, the HLW Salt Disposition Program Manager chartered ${ }^{2}$ the HLW Tank Space Management Team (SM Team) to use the Systems Engineering (SE) approach to identify, evaluate, and recommend "the best management practices (Strategy) for safe stewardship of high level waste while maximizing available tank space". The SM Team was sponsored by the original HLW Salt Disposition System Engineering Team.

\subsection{Systems Engineering}

The SE approach was required by the Charter ${ }^{2}$ and recognized by the SM Team as the most appropriate method for accomplishing the assigned task. The SM Team developed a Systems Engineering Management Plan (SEMP) ${ }^{3}$ to provide a top level description of the methodology, tools, deliverables, and schedules required to implement the systems engineering approach for SM Team activities. The SEMP ${ }^{3}$ served as the guidance document on how the SM Team would systematically seek out a recommended Strategy.

Implementation of the SE approach resulted in three phases of SM Team activities:

- Identification

- Evaluation

- Selection

The Identification Phase comprised, problem definition, mission need, key assumptions, necessary and sufficient functions and requirements which were defined in the Strategy Input Package (SIP) ${ }^{5}$. Ideas relative to tank space management were then solicited from Subject Matter Experts, Stakeholders, and SRS employees. Approximately 300 ideas were submitted, combined to eliminate duplication, categorized, and screened against "Go/No Go" criteria ${ }^{6,7}$. The Identification Phase ended with the Initial List ${ }^{8}$ of ideas to be carried forward and evaluated by the SM Team.

The Evaluation Phase focused on developing the Initial List ${ }^{8}$ of concepts into detailed descriptions to facilitate combining and assessing them for space gain contributions, risk, cost/schedule to implement, impact on site missions, and compatibility with existing HLW processes. These evaluations led to the Intermediate List ${ }^{9}$ of 24 ideas and subsequent Short List of four Strategies.

The Selection Phase involved a review of the Evaluation Phase outputs combined with SM Team expertise to recommend a Strategy for HLW tank space management. 


\section{$1.4 \quad$ Dissenting Opinions}

The SM Team implementation of the SE process was predicated on a consensus philosophy. If consensus was not reached by the SM Team members during any decision or phase of SM Team activities, a formal Dissenting Opinion vehicle existed to document the opposing view(s). The SM Team procedure ${ }^{6}$ for this process requires that all Dissenting Opinions be made part of the Final Report. There were no Dissenting Opinions generated during the SM Team's activities.

\subsection{SM Team Members and External Input}

SM Team members were chosen to provide expertise in Systems Engineering, Process Engineering, HLW Operations and Maintenance, HLW Programs, Safety and Regulatory Engineering, and HLW Tank Farm Engineering and local public perspective. WSRC engineering and administrative support resources were available to, and managed by, the SM Team as needed to complete the Chartered activities.

\subsection{Risk Management}

During the Evaluation Phase, risk analysis was implemented on the Intermediate List of ideas and Short List of Strategies. Subject Matter Experts (SMEs) and stakeholders participated at the request of the SM Team.

A customized checklist of risk screening questions in the areas of mission impacts, receipt, storage, processing and removal of HLW was developed and applied to each of the Intermediate List ideas. Statements of risk applicable to each of the ideas were documented, and qualitative estimates of probability and consequence levels for these risks were assessed. High risks were assigned risk-handling strategies. The risks were also used to eliminate Intermediate List ideas with high residual risks. The risk analysis was also performed on the developed Short List of Strategies, to determine if the combining of individual ideas into a Strategy resulted in new or additional unique risks. The risk analysis on Strategies produced no new notable risks.

\subsection{Cost}

The SM Team evaluation of cost became more detailed as the space gains and implementability of alternative Strategies became more refined. Initially, broad estimates of cost were used to see if alternatives were credible. $\mathrm{No}^{13}$ alternative Strategies were eliminated on this basis. Order of magnitude estimates were established based on previous experience, or in comparison to other facilities. More detailed cost estimates will be developed as scope is better defined for each of the ideas when they are closer to implementation. 


\section{$1.8 \quad$ Recommendation}

The SM Team's recommended overall Strategy consists of the following key features:

- Continue to evaporate liquid waste, including the backlog waste that has not been concentrated as much as possible, throughout the period;

- Use Tank 49 for general HLW storage instead of assigning it to the ITP process;

- Install an evaporator in the DWPF salt cell to eliminate the current practice of returning DWPF aqueous byproduct waste ("DWPF Recycle") to the HLW Tank Farms;

- Return Tank 50 to HLW service in 2004 by installing a staging tank between ETF and $Z$ Area for ETF bottoms and operating saltstone intermittently;

- When appropriate, implement ideas that gain small incremental volumes (less than $900 \mathrm{Kgal}$ ) that were identified by the SM Team as part of this work; and

- If necessary near the end of the period, incrementally reduce the minimum emergency space (presently set at $2600 \mathrm{Kgal}$ for the $\mathrm{F}$ and $\mathrm{H}$ Tank Farms) to the AB minimum requirement of $1300 \mathrm{Kgal}$.

In addition to these recommended actions, other tank farm practices and plans need to be continued, such as startup of the Replacement High Level Waste Evaporator (RHLWE), maintenance of waste tanks and related equipment, and removal of waste from older tanks.

A key assumption used in the development of this Strategy was that the alternative Salt Processing Facility would be operating by the end of FY2009. If there is a delay in the alternative salt processing facility the project for the construction of new HLW tanks should be pursued, however, this would have a significant an unfavorable cashflow impact.

\subsection{Deliverables}

This report satisfies the final report deliverable on SM Team activities and supersedes previously approved documentation issued by the SM Team. Submittal of this report completes the chartered SM Team activities. An index of references is shown in Figure 1-1 to facilitate the reading of this report.

A continued review of the implementation and optimization of this report will be made through subsequent issues of the HLW System Plan. In addition, WSRC will continue to monitor progress versus the Available Space Baesline (ASB) ${ }^{4}$ through programs that have been established to track and trend HLW tank farm space management. 


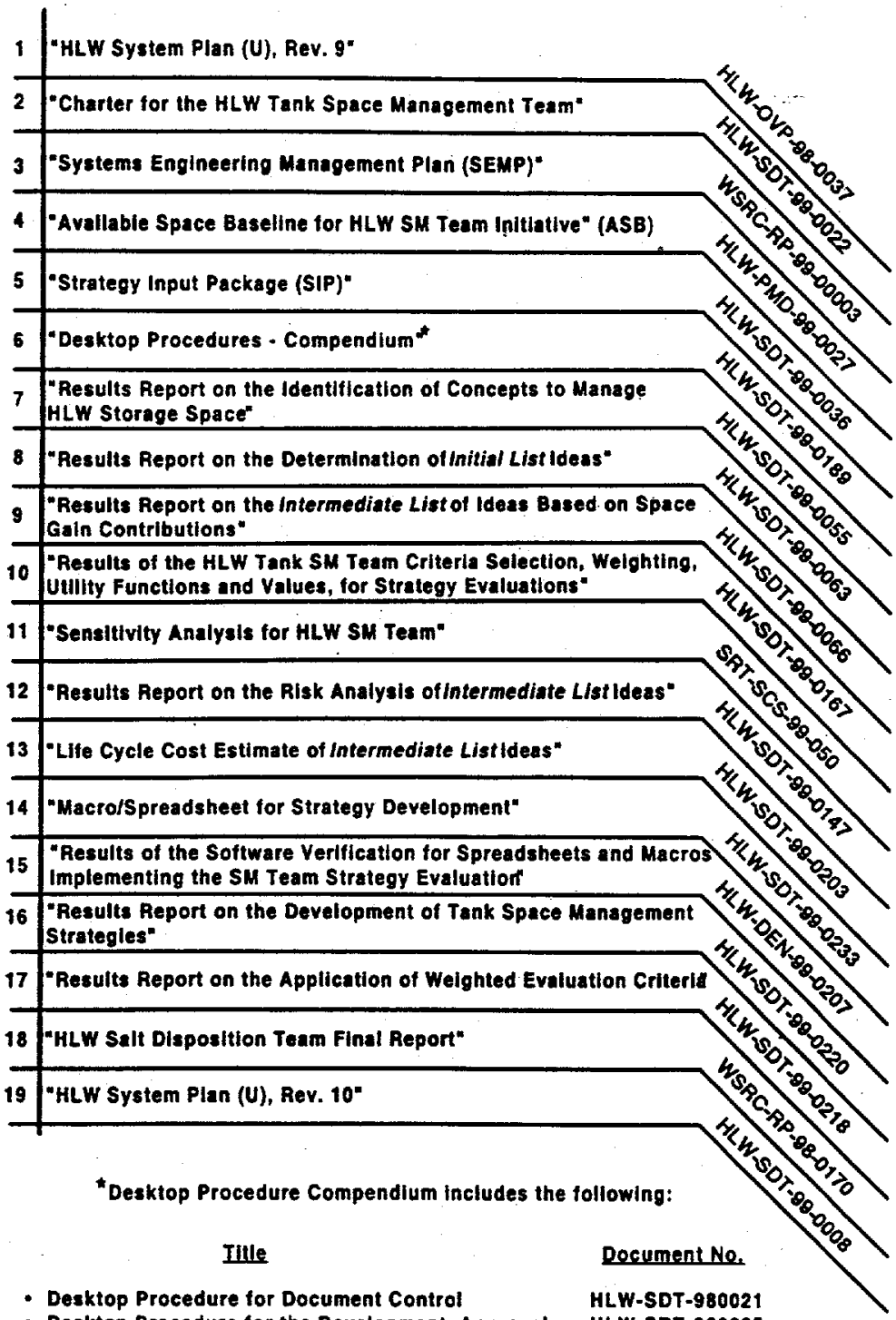

- Desktop Procedure for Document Control

- Desktop Procedure tor the Development, Approval and Control of Desktop Procedures

- Desktop Procedure tor Intormation Handiling. Analysis, and Reporting

- Desktop Procedure for the Identification and Documentalion of Dissenting Opinions

- Desktop Procedure tor the Training of Personnel

- Desktop Procedure for HLW Salt Disposition Team Records and Document Management and Storage

- Desktop Procedure for Change Control

- Desktop Procedure for Team Reports

- Desktop Procedure for Engineering Change Control

- Desktop Procedure for the Application of Screening Criteria

- Desktop Procedure for the Identification of Concepts HLW-SDT-990039 to Manage HLW Storage Space

- Desktop Procedure for Dispositioning the Initial List HLW-SDT-990044 Ideas Based on Avallable Space Contributions

- Desklop Procedure for Risk Analysis

- Desktop Procedure tor the Applicalion of wi Evaluation Criteria

- Desktop Procedure for Strategy Development HLW-SDT-990177

- Desktop Procedure for the HLW Tank Space Strategy HLW-SDT-99022 Selection Process

Figure 1-1: Documents Developed and/or Referenced in Final Report 


\subsection{Introduction and Purpose}

The SRS Site Treatment Plan (STP) and Federal Facilities Agreement (FFA) call for closing the HLW Tanks through vitrification of both the long-lived and short-lived radioisotopes in DWPF in preparation for transport to the national high level waste repository. To make this program economically feasible, it is necessary to limit the volume of HLW glass produced by removing much of the non-radioactive salts and incidental wastes for disposal as saltstone. The ITP facility was designed and constructed to separate the cesium isotopes from the non-radioactive salts so the decontaminated salts could be disposed in a grouted wasteform at the Saltstone facility at SRS.

The ITP process was successfully piloted both on a moderate and full-scale basis with actual SRS waste in the 1980s. During the facility radioactive startup, higher than predicted benzene releases were observed. Additional laboratory and facility tests were initiated to further investigate process chemistry issues. In January 1998, conclusions were drawn from the test program that the benzene release rates associated with facility operation could exceed the capability of the current plant hardware/systems. On January 22,1998 , WSRC informed DOE that ITP chemistry testing demonstrated that the present system configuration could not cost-effectively meet the safety and production requirements for the ITP facility and recommended that a study of alternatives to the current system configuration be conducted by a systems engineering team.

On February 6, 1998, the Assistant Secretary for Environmental Management approved a DOE-SR plan of action to suspend startup-related activities and undertake a systems engineering study of alternatives to ITP. On February 20, 1998, DOE-SR concurred with the WSRC evaluation of the ITP chemistry data, instructed WSRC to suspend ITP startup preparations, and directed WSRC to perform an evaluation of alternatives to the current system configuration for HLW salt removal, treatment, and disposal.

In March 1998, a WSRC-sponsored High Level Waste Systems Engineering Team was formed to study alternatives to the ITP processes as well as methods to enhance the current process. The multi-disciplined Team was chartered with the task of "systematically developing and recommending an alternative method and/or technology for disposition of HLW salt."

On October 29, 1998, the WSRC HLW Systems Engineering Team provided their recommendation to the DOE. The recommendation was to pursue the Small Tank TPB precipitation process as the preferred alternative and Crystalline Silicotitanate NonElutable Ion Exchange as a backup technology. 
On January 28,1999 , the DOE completed their review of the recommendation and developed a path forward, which requested WSRC to take six actions as described below:

1) Initiate actions necessary to support the NEPA (Supplemental EIS) process (e.g., evaluate effects on Saltstone Performance Assessment (PA) from the variations in the feeds from the three alternatives and provide support as needed to resolve issues identified.

2) Expand Tank Farm water/salt management studies and develop a Strategy and plan to maximize existing tank space flexibility in order to accommodate any of the alternatives.

3) Perform parallel research and development (R\&D) activities to address the technical uncertainties associated with the Crystalline Silicotitanate (CST) Ion Exchange and Small Tank Tetraphenylborate (TPB) Precipitation alternatives.

4) Evaluate the use of existing Tank Farm facilities for the removal of uranium, plutonium, neptunium and strontium from the HLW salt solutions.

5) Provide support to DOE-SR as needed for the Direct Disposal in Grout alternative, including any necessary $R \& D$ activities.

6) Initiate further design development only for issues that are common to all alternatives.

On February 26, 1999, the WSRC HLW Salt Disposition Program Manager chartered the HLW Tank Space Management Team (SM Team) to address the second item defined above.

The charter for the SM Team identified the following deliverables:

- A HLW System Analysis with bases

- Proposed and drafted permit changes

- Approved baseline changes to the HLW Salt Disposition Systems Engineering Team controlled documents

- An overview of the SM Team activities and process used.

- Because the Salt Disposition Facility will not be operational for about a decade, HLW System Plan (Rev. 9) ${ }^{1}$, which assumes that ITP will be operational, is obsolete. Thus, the HLW Tank Space Management Team was chartered ${ }^{2}$ to apply the Systems Engineering process to identify, evaluate, and recommend a Strategy that provides for the safe and cost effective space management of HLW -

This report constitutes the "Final Report" required by the SM Team Charter. 


\section{$2.1 \quad$ Background}

High Level Waste has been produced at the Savannah River Site since 1954. This waste was stored in Interim Waste Tanks. In the early 1980s, a concept was developed to no longer construct additional Interim Waste Tanks, but to process the waste into a safer storage form, reduce risk, and ready the waste for permanent storage. This led to an initial design concept for DWPF and an Ion Exchange Facility.

The cost for both facilities was high, and technical uncertainties for Ion Exchange posed a high risk. Alternatives to the Ion Exchange Process were evaluated and the ITP process was selected due to lower projected cost and technical risk.

The Savannah River Site currently stores 34 million gallons of $H L W$ in Interim Storage Tanks. This activity is considered to be one of the higher risk activities on the Site. The FFA and STP require removing the waste from the high level waste tanks to resolve several safety and regulatory concerns. The "old style" tanks (tanks 1 - 24), do not meet EPA secondary containment standards for storage of hazardous waste, (effective January 12, 1987). Several of the "old style" tanks have leaked observable quantities of waste from primary to secondary containment. Other tanks have known penetrations above the liquid level, although no waste has been observed to leak through these penetrations. The 34 million gallons of liquid waste stored in the HLW tanks are composed of 31 million gallons of salt and 3 million gallons of sludge. The process to treat and vitrify sludge has been operational since December 1995 . The ITP process was the baseline method intended for handling salt.

The WSRC HLW Salt Disposition Systems Engineering Team completed their chartered activities and presented their recommendations to DOE on October 29, 1998. The DOE requested additional studies and environmental impact evaluations to be done. The net effect of the suspension of ITP, and additional studies is a delay in HLW salt processing of about eight to ten years.

\subsection{High Level Waste System Overview}

Any new HLW Tank Space Management Strategy must consider the interfaces with existing facilities, and the ease or difficulty of the successful implementation of an alternative technology as governed by how well it will integrate into the existing HLW System.

The mission of the HLW System is to receive and store SRS high level wastes in a safe and environmentally sound manner and to convert these wastes into forms suitable for final disposal. The planned forms are:

- borosilicate glass to be sent to a Federal Repository 
- saltstone to be disposed of on site

- treated wastewater to be released to the environment.

Also, the storage tanks and facilities used to process the high level waste must be left in a state such that they can be decommissioned and closed in a cost-effective manner and in accordance with appropriate regulations and regulatory agreements.

The HLW System is a set of seven different interconnected processes (Figure 2-1) operated by the High Level Waste and Solid Waste Divisions. These processes function as one large treatment plant that receives, stores, and treats high level wastes at SRS and converts these wastes into forms suitable for final disposal.

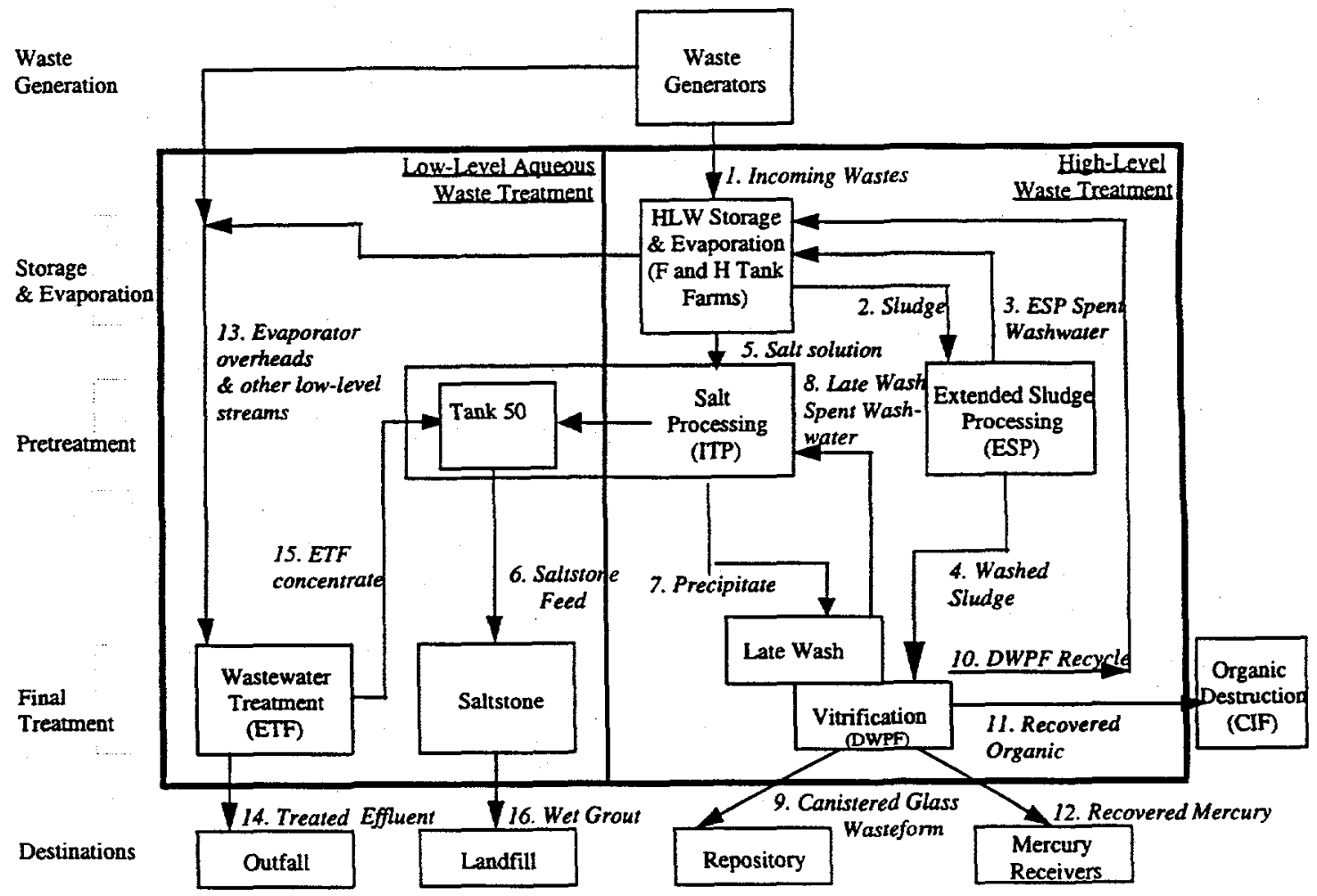

Figure 2-1: HLW System Major Interfaces

These processes currently include:

- High Level Waste Storage and Evaporation (F and H Area Tank Farms)

- Salt Processing (In Tank Precipitation and Late Wash Facilities) 
- Sludge Processing (Extended Sludge Processing Facility)

- Vitrification (DWPF)

- Wastewater Treatment (Effluent Treatment Facility)

- Solidification (Saltstone Facility)

- Organic Destruction (Consolidated Incineration Facility)

$\mathrm{F}$ and $\mathrm{H}$ Area Tank Farm, Extended Sludge Processing, DWPF, Effluent Treatment Facility, Saltstone Facility, and the Consolidated Incineration Facility are all operational. ITP Facility operations are limited to safe storage and transfer of materials. The Late Wash Facility has been tested and is in a dry lay-up status.

All high level wastes in storage at SRS are classified Land Disposal Restrictions (LDR) wastes, which are prohibited from permanent storage. Since the planned processing of these wastes will require considerable time and therefore continued storage of the waste, DOE has entered into a compliance agreement with the EPA and SCDHEC. This compliance agreement is implemented through the STP, which requires processing of all the high level waste at SRS according to a schedule negotiated between the parties.

Figure 2-1 schematically illustrates the routine flow of wastes through the HLW System. The various processes within the system and external processes are shown in rectangles. The numbered streams identified in italics are the interface streams between the various processes. The discussion below represents the HLW System configuration as of January 1998.

Incoming high level wastes are received into HLW Storage and Evaporation (F and $\mathrm{H}$ Area Tank Farms) (Stream 1). The function of HLW Storage and Evaporation is to safely concentrate and to store these wastes until downstream processes are available for further processing. The decontaminated liquid from the evaporators are sent to Wastewater Treatment (ETF) (Stream 13).

The insoluble sludges that settle to the bottom of waste receipt tanks in HLW Storage and Evaporation are slurried using hydraulic slurrying techniques and sent to Extended Sludge Processing (ESP) (Stream 2). In ESP, sludges high in aluminum are processed to remove some of the insoluble aluminum compounds. All sludges, including those that have been processed to remove aluminum, are washed with water to reduce their soluble salt content. The spent washwater from this process is sent back to the HLW Storage and Evaporation (Stream 3). The washed sludge is sent to Vitrification (DWPF) for feed pretreatment and vitrification (Stream 4).

Saltcake is redissolved using hydraulic slurrying techniques similar to sludge slurrying. As currently designed, the salt solutions from this operation, and other 
salt solutions from HLW Storage and Evaporation, were intended for feed to Salt Processing (Stream 5). In ITP, the salt solution would be processed to remove radionuclides, which are concentrated into an organic precipitate. The decontaminated filtrate would then be sent to Tank 50. A concentrated organic precipitate, containing most of the radionuclides, is produced by the process. This precipitate is washed with water to remove soluble salts. However, some soluble corrosion inhibitors that interfere with DWPF processing must be left in the precipitate after washing because the precipitate is stored in carbon steel tanks, which are susceptible to corrosive attack by uninhibited precipitate wastes.

The precipitate is transferred to Late Wash for further washing in stainless steel tanks to reduce the level of soluble corrosion inhibitors to acceptable levels for the DWPF process (Stream 7). The washwater from this process is returned to ITP to be reused in the ITP process (Stream 8).

The washed precipitate from Late Wash is then sent to the DWPF vitrification building (221-S). In the vitrification building, the precipitate is catalytically decomposed and separated into two streams: a mildly contaminated organic stream and an aqueous stream containing virtually all of the radionuclides. The mildly contaminated organics are stored at DWPF and eventually transferred to Organic Destruction (CIF) (Stream 11). The aqueous stream is combined with the washed sludge from ESP, which has undergone further processing and the mixture vitrified.

The washed sludge from ESP (Stream 4) is chemically adjusted in the DWPF to prepare the sludge for feed to the glass melter. As part of this process, mercury is stripped out, purified, and sent to mercury receivers (Stream 12). The aqueous product from organic decomposition is added to the chemically adjusted sludge. The mixture is then combined with glass frit and sent to the glass melter. The glass melter drives off the water and melts the wastes into a borosilicate glass matrix, which is poured into a canister. The canistered glass wasteform is sent to site interim storage, and will eventually be disposed of in a Federal Repository (Stream 9).

The water vapor driven off from the melter along with other aqueous streams generated throughout the DWPF vitrification building is recycled to HLW Storage and Evaporation for processing (Stream 10).

Overheads from the HLW Storage and Evaporation evaporators are combined with overheads from evaporators in the $\mathrm{F}$ and $\mathrm{H}$ Area Separations processes and other low-level streams from various waste generators. This mixture of low-level wastes is sent to the ETF (Stream 13).

In the ETF, these low-level wastes are decontaminated by a series of cleaning processes. The decontaminated water effluent is sent to the $\mathrm{H}$ Area outfall and 
eventually flows to local creeks and the Savannah River (Stream 14). The contaminants removed from the water are concentrated and sent to Tank 50 (Stream 15).

In Tank 50, the concentrate from the ETF is combined with the decontaminated filtrate from the ITP and sent to Saltstone (Stream 6). In the Saltstone Facility, the liquid waste is combined with cement formers and pumped as a wet grout to a vault (Stream 16). In the vault, the cement formers hydrate and cure, forming a saltstone monolith. The Saltstone Facility vaults will eventually be closed as a landfill.

\subsection{HLW Tank Space Management Team}

The WSRC HLW Salt Disposition Program Manager (Steve Piccolo) selected the members of the HLW Tank Space Management Team in accordance with the requirements of the Charter ${ }^{2}$. Members are identified below by area of contribution and organizational affiliation. The focus of the SM Team Charter was to recommend a Strategy for the management of HLW storage space until at least the year 2009 .

NAME

Robert Malloy

Marshall Miller

Gary Abell

John Fowler

Rick Fowler

Paul d'Entremont

Richard Garrett

Mark Mahoney

Lee Poe

Robert Wilson
AREA OF CONTRIBUTION

Team Sponsor*

Team Leader**

Systems Engineering

Process Engineering \& Chemistry

Process Engineering

HLW Tank Farms Engineering

Safety and Regulatory Engineering

HLW Programs

Public Perceptions of HLW

HLW Operations/Maintenance

\begin{tabular}{c} 
AFFILIATION \\
\hline WSRC \\
WSRC \\
WSRC \\
WSRC \\
WSRC \\
WSRC \\
WSMS \\
WSRC \\
Consultant \\
WSRC
\end{tabular}

* The SM Team Sponsor acted as a formal liaison between the HLW Salt Disposition Systems Engineering Team and the SM Team.

** The SM Team Leader acted as the formal point of contact with the WSRC Program Manager and DOE.

\subsection{HLW Tank Space Team Subject Matter Experts (SMEs)}

The SM Team utilized various SMEs in the process. These individuals provided technical, maintenance, operation, and regulatory expertise. 


\subsection{Recommended Overall Strategy}

The SM Team's recommended Overall Strategy is discussed in this section. The implementation plans, costs, schedules and uncertainties associated with the Overall Strategy are included. The Overall Strategy will provide a safe and cost-effective means to manage High Level Waste (HLW) at the SRS through FY2009. The Systems Engineering methodology and the results used to identify, evaluate and select the Overall Strategy are discussed in Sections 4.0 through 9.0 of this report.

A key assumption used to develop the Overall Strategy is that the new Salt Processing Facility will be operational by the end of FY2009. The Overall Strategy combines Strategy S-17 (as described in Section 9.3) with the Small Volume Gain Ideas (SVGI) described in Section 7.4. The Overall Strategy provides these advantages for managing HLW through 2009:

(1) Minimal impact on cash flow and budgets compared to the HLWMD Base Case Planning Model.

(2) Slightly higher Increase in Available Space (IAS) than required in all years over the entire ten-year study period. Higher IAS provides some flexibility in operations and will offset unexpected increases in waste volumes or other events not anticipated by the SM Team.

(3) A flexible schedule that delays a reduction in Emergency Space until late in the study period, and the Emergency space would only be implemented if space is needed to continue Tank Farm operations.

(4) The use of existing facilities and processes is maximized.

Failure to implement the Overall Strategy or to assure the Salt Processing Facility is operational by FY2009 could lead to a significant increase in the Life Cycle Costs for managing and disposal of the HLW now stored in waste tanks at the SRS. If the significant delays occur in the project for the Salt Processing Facility, an additional major project to construct four HLW waste tanks on an accelerated schedule would be required to assure additional storage space is available beyond FY2009.

\subsection{Overall Strategy Description}

The initiatives included in the Overall Strategy are shown in Table 3-1. The Overall Strategy continues the current practice to recover space in the Tank Farm by evaporation of current and future waste to higher salt concentrations. Work must begin in FY2000 to implement the Small Volume Gain Ideas (SVGI), to recover and reuse Tanks 49 (IL-22) and 50 (IL-21) for HLW storage and to design and install an evaporator in the DWPF Salt Cell (IL-11) to eliminate DWPF recycle as an influent to the Tank Farm. As noted above, Emergency Space would be reduced to the Authorization Basis (AB) minimum value of $1300 \mathrm{~K}$-gal (IL-17) only if necessary to continue Tank Farm Operations. 
Table 3-1: Ideas Included in Overall Strategy

\begin{tabular}{|l|c|c|}
\hline \multicolumn{1}{|c|}{ Ideas } & $\begin{array}{c}\text { Fiscal } \\
\text { Year IAS } \\
\text { Occurs }\end{array}$ & $\begin{array}{c}\text { Total } \\
\text { IAS } \\
\text { Gained, } \\
\text { K-gals }\end{array}$ \\
\hline Continue to Evaporate Waste (IL-10) & $\begin{array}{c}2000-20 \\
09\end{array}$ & 1,526 \\
\hline $\begin{array}{l}\text { Implement Small Volume Gain Initiatives (ideas < 900 } \\
\text { K-gal each) }\end{array}$ & $\begin{array}{c}2000-20 \\
09\end{array}$ & 2,083 \\
\hline Recover and Reuse Tank 49 (IL-22) & 2001 & 1,060 \\
\hline $\begin{array}{l}\text { Eliminate DWPF Recycle to HLW Tank Farm by Acid } \\
\text { Evaporation of DWPF Recycle in Salt Cell (IL-11) }\end{array}$ & $\begin{array}{c}2004-20 \\
09\end{array}$ & 1,176 \\
\hline $\begin{array}{l}\text { Return Tank 50 to HLW Service By Installing a New Tank for Staging } \\
\text { of ETF Bottoms to be sent to Z Area (L-21) }\end{array}$ & 2004 & 1,200 \\
\hline $\begin{array}{l}\text { Reduce 2.6 M-gals Emergency Space to 1.3 M-gal (AB } \\
\text { Limit) (IL-17) }\end{array}$ & If needed & 1,300 \\
\hline
\end{tabular}

The SVGI used in the Overall Strategy include these ideas:

- Reevaluate the specifications contained in the Tank Farm WAC and remove excess conservatism to minimize the quantity of salt added to incoming wastes.

- Add telescoping jets to some HLW Tanks to allow more complete transfers thus minimizing heels of waste that is not concentrated as much as possible.

- Use HLW supernate with high caustic molarity for aluminum dissolution.

- Review DWPF operations and change current practices to minimize recycle to Tank Farm such as reducing steam flow to the melter off-gas system during periods of melter shutdown, bypassing the Low Point Pump Pit to minimize pump priming, and repairing the pump priming line on the SMECT transfer pump. [Note: Gains from these ideas can only be realized until evaporation of DWPF aqueous waste begins (i.e., before Idea IL-21 is implemented).]

- Use Tank $26 \mathrm{~F}$ for concentrated supernate storage after placing the $2 \mathrm{~F}$ Evaporator in warm standby, thus reducing the working space required for continuing operations in the Tank Farm.

- Use Type IV tanks to store dilute spent wash water from ESP.

Table 3-2 summarizes the IAS from each idea in the Overall Strategy and compares it to the Annual Space Baseline (ASB) Requirement that served as the basis for evaluating strategies in this study. Emergency Space is reduced in FY2007 in Table 3-2 to yield the maximum cumulative IAS for the Overall Strategy, but this reduction may not be needed if the projected volume gains from all other ideas are realized or waste influents are less than forecasted. The 
projected ten-year IAS for the SVGI (up to $2100 \mathrm{~K}$-gal) more than compensates for the IAS that would be provided by reducing Emergency Space to the AB minimum value $(1300 \mathrm{~K}$-gal). Conversely, if the projected IAS from the SVGI or any other idea cannot be fully achieved, reducing Emergency Space provides buffer capacity for the overall IAS.

Table 3-2: Cumulative IAS for the Overall Strategy, K-gals

\begin{tabular}{|l|c|c|c|c|c|c|c|c|c|c|}
\hline \multirow{2}{*}{\multicolumn{1}{c|}{ Ideas in Overall Strategy }} & \multicolumn{10}{|c|}{ Fiscal Year } \\
\cline { 2 - 11 } & $\mathbf{2 0 0 0}$ & $\mathbf{2 0 0 1}$ & $\mathbf{2 0 0 2}$ & $\mathbf{2 0 0 3}$ & $\mathbf{2 0 0 4}$ & $\mathbf{2 0 0 5}$ & $\mathbf{2 0 0 6}$ & $\mathbf{2 0 0 7}$ & $\mathbf{2 0 0 8}$ & $\mathbf{2 0 0 9}$ \\
\hline Continue to Evaporate Waste (IL-10) & 759 & 1526 & 1526 & 1526 & 1526 & 1526 & 1526 & 1526 & 1526 & 1526 \\
\hline Implement Small Volume Gain Ideas & 15 & 393 & 665 & $\mathbf{8 7 9}$ & 928 & $\mathbf{9 7 7}$ & 1285 & 1599 & 1713 & 2083 \\
\hline Recover \& Reuse Tank 49 (IL-22) & 0 & 1060 & 1060 & 1060 & 1060 & 1060 & 1060 & 1060 & 1060 & 1060 \\
\hline $\begin{array}{l}\text { Eliminate DWPF Recycle to HLW Tank } \\
\text { Farm by Acid Evaporation of DWPF } \\
\text { Recycle in Salt Cell (IL-11) }\end{array}$ & 0 & 0 & 0 & 0 & 196 & 392 & 588 & 784 & 980 & 1176 \\
\hline $\begin{array}{l}\text { Return Tank 50 to HLW Service By } \\
\text { Installing New Tank for Staging of ETF } \\
\text { Bottoms for Z Area (IL-21) }\end{array}$ & 0 & 0 & 0 & 0 & 1200 & 1200 & 1200 & 1200 & 1200 & 1200 \\
\hline $\begin{array}{l}\text { Reduce 2.6 M-gals Emergency Space to } \\
\text { 1.3 M-gal (AB Limit) (IL-17) }\end{array}$ & 0 & 0 & 0 & 0 & 0 & 0 & 0 & 1300 & 1300 & 1300 \\
\hline Cumulative IAS & $\mathbf{7 7 4}$ & $\mathbf{2 9 7 9}$ & $\mathbf{3 2 5 6}$ & $\mathbf{3 4 6 9}$ & $\mathbf{4 9 4 3}$ & $\mathbf{5 2 0 3}$ & $\mathbf{5 6 5 6}$ & $\mathbf{7 4 7 5}$ & $\mathbf{7 7 3 5}$ & $\mathbf{8 2 5 0}$ \\
\hline ASB Requirement & $\mathbf{5 0 0}$ & $\mathbf{1 3 7 8}$ & $\mathbf{1 9 4 4}$ & $\mathbf{2 4 1 9}$ & $\mathbf{2 7 8 3}$ & $\mathbf{3 3 7 8}$ & $\mathbf{3 8 8 6}$ & $\mathbf{4 9 8 7}$ & $\mathbf{5 2 9 9}$ & $\mathbf{6 0 4 3}$ \\
\hline
\end{tabular}

The SM Team stresses the importance of the SVGI to achieve the IAS projected for the Overall Strategy. The projected cumulative IAS from the SVGI for each Fiscal Year is shown in Table 3-3.

Table 3-3: Cumulative IAS for Small Volume Gain Ideas, K-gals

\begin{tabular}{|l|c|c|c|c|c|c|c|c|c|c|}
\hline & \multicolumn{7}{|c|}{ Fiscal Year } \\
\cline { 2 - 11 } Initial List Ideas Used for SVGI (Idea No.) & 2000 & 2001 & 2002 & 2003 & 2004 & 2005 & 2006 & 2007 & 2008 & 2009 \\
\hline $\begin{array}{l}\text { Modify Practices Related to DWPF Recycle } \\
\text { and Operations (D-19, D-28, D-30) }\end{array}$ & 15 & 38 & 61 & 84 & 84 & 84 & 84 & 84 & 84 & 84 \\
\hline $\begin{array}{l}\text { Add Telescoping Transfer Jets to Evaporator } \\
\text { System Tanks (T-13) }\end{array}$ & & 300 & 500 & 500 & 500 & 500 & 500 & 500 & 500 & 500 \\
\hline $\begin{array}{l}\text { Revise Tank Farm WAC to Reduce Excess } \\
\text { Inhibitors (A-18) }\end{array}$ & 0 & 48 & 96 & 144 & 192 & 240 & 288 & 336 & 384 & 48 \\
\hline $\begin{array}{l}\text { Optimize ESP Washing Using DWPF Recycle } \\
\text { (W-33) }\end{array}$ & 0 & 7 & 7 & 14 & 14 & 14 & 14 & 14 & 14 & 14 \\
\hline $\begin{array}{l}\text { Use High Caustic Waste for Al-Dissolution } \\
\text { (W-29) }\end{array}$ & 0 & 0 & 0 & 135 & 135 & 135 & 329 & 329 & 329 & 585 \\
\hline Shutdown 2F Evaporator System (T-87) & 0 & 0 & 0 & 0 & 0 & 0 & 0 & 200 & 200 & 200 \\
\hline Other (C-20, T-24, A-12, A-13, A-14, T-9) & 0 & 0 & 1 & 2 & 3 & 4 & 5 & 6 & 7 & 8 \\
\hline Cumulative IAS & 15 & 393 & 665 & 879 & 928 & 977 & 1285 & 1599 & 1713 & 2083 \\
\hline
\end{tabular}


Figure 3-1 compares the Overall Strategy's IAS from Table 3-2 with the IAS for Strategy S-17 and the ASB Requirement. The top curve shows the maximum space gain from the Overall Strategy and is based on the assumption that all of the initiatives are fully implemented, including the reduced Emergency Space (II-17) in FY2007. The middle curve shows the IAS for Strategy S-17 without the SVGI included. The bottom curve shows the ASB Requirement used for this study. The SM Team stresses the importance of the Small Volume Gains to achieve the IAS projected for the Overall Strategy. The SM Team judged that the magnitude of uncertainty associated with the IAS is represented by the difference between the curve for the Overall Strategy and the curve for Strategy S-17 shown in Figure 3-1.

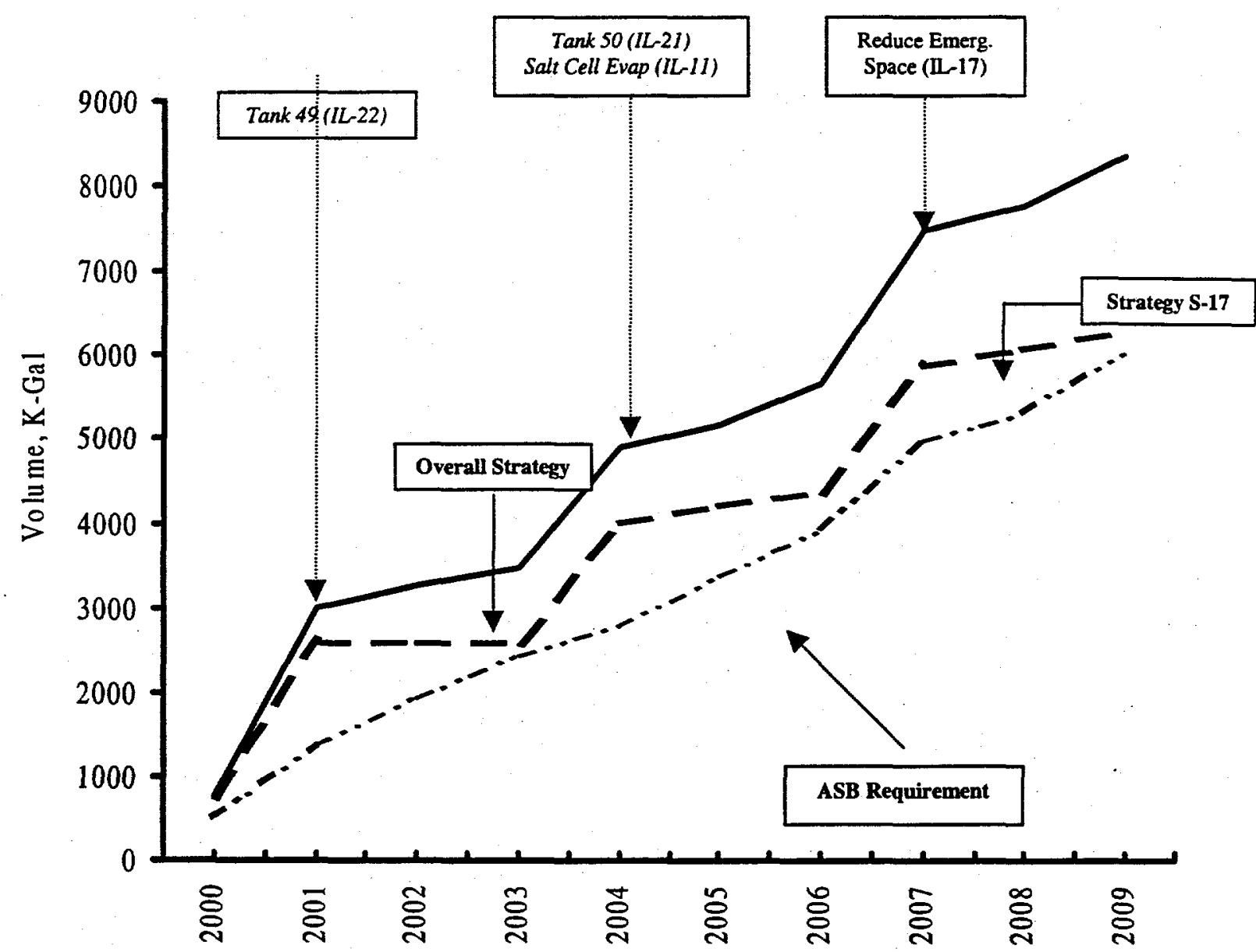

Fiscal Year

Figure 3-1: Comparison of IAS of Overall Strategy to IAS of Strategy S-17 and ASB Requirement 


\subsubsection{Evaporate Waste}

This Idea (IL-10) continues the current Tank Farm operations using HLW evaporators to gain approximately $1,500 \mathrm{~K}$ gal of space in the Tank Farm. Volume gained from this idea comes from evaporating approximately $3,500 \mathrm{~K}$ gal of waste now stored in Tanks $30,35,39$ and 40 . Salt solution has been stored in these tanks for several years in anticipation of providing feed to the In-Tank Precipitation (ITP) process. With the delay of salt solution processing due to safety issues surrounding ITP, this "backlog waste" should be further evaporated to increase the available space in the Tank Farm.

The idea for evaporation of backlog waste is in every Strategy evaluated by the SM Team. Implementation of this idea began in FY99 when Tank 35 material was transferred to Tank 32 in July 1999. This idea relies on normal waste transfers and evaporation in the Tank Farm.

Though new procedures must be developed to process the waste already in the Tank Farm, no new equipment is required to implement this idea for the space gain value specified above. However, the number of transfers made in the Tank Farm annually must increase significantly. For example, the planned FY2000 tank-to-tank transfers to evaporate the backlog waste and to prepare Sludge Batch 2 are about triple the number of transfers made over the last three years combined.

The logistics of increasing available space by evaporating backlog waste while also supporting other key activities (e.g., DWPF processing) will be a major challenge for $\mathrm{HLWD}$. In addition, the $2 \mathrm{~F}$ Evaporator is nearing the end of its design life while the RHLWE (3H Evaporator) is still in a startup mode and was assumed to be operational by October 1999 for this study.

Principal risks for this idea are related to availability of evaporators for processing the waste and infrastructure to transfer waste to an evaporator feed tank when additional feed is needed. If the $2 \mathrm{~F}, 2 \mathrm{H}$ and $3 \mathrm{H}$ evaporators can not operate as planned, the ability to gain space from evaporating waste would be severely reduced. If the planned IAL for IL10 is not achieved, then other processing impacts could occur. The most notable impact would occur in FY2000. If available space cannot be increased by evaporation, Sludge Batch 2 processing could be delayed unless other IAS ideas are implemented (e.g. use of Type IV tanks for ESP wash water storage). 
Longer-term, failure to evaporate dilute waste could result in a "water-logged" condition in the HLW Tank Farm System. If this occurs, other Site operations must shut down because waste storage space for new receipts or pretreatment operations is unavailable. Processes that could be affected include NMSS Processed Waste, DWPF, and sludge washing operations in ESP.

\subsubsection{Small Volume Gain Ideas (SVGI)}

As described in Section 6.4, fifteen ideas were identified that have the potential to yield small increases in available space. These fifteen ideas fall into two main categories. Some provide small volume gains ranging up to about $600 \mathrm{~K}$-gal. Others suggest better mechanisms (e.g., by changing operating practices or develop better tracking indicators) that should be evaluated further. Even if the space gains from these ideas are small, they could result in better space forecasting to better manage the available space. If successfully implemented, the small volume gain ideas could also result in overall cost savings if they eliminate the need for other more costly space gain ideas. For example, the successful implementation of all the SVGI is estimated to provide an increase in TIAS of up to 2 million gallons. This IAS could eliminate the need for reducing the Emergency Space from its current value of 2.6 million gallons.

Overall, the SM Team recommends that each of the fifteen ideas be evaluated further and implemented where appropriate. Although individually these ideas may not provide significant space savings, their collective implementation could provide the equivalent of at least one HLW Waste Tank. In addition, implementation of the SVGI demonstrates HLW's proactive search for ways, both large and small, to increase the available space in the Tank Farms. Submission of new ideas is encouraged and will be added to the list for evaluation, as appropriate.

The small volume space gain ideas are listed in Table 7-3 of this report. Some of the more promising SVGI are described in more detail below.

\section{- $\quad$ Perform Aluminum Dissolution with High Hydroxide Waste}

This idea proposes to use existing concentrated supernate that is high in $\mathrm{OH}$ for aluminum dissolution rather than adding fresh sodium hydroxide. If successfully implemented, the loss of approximately $600 \mathrm{~K}$-gal of available space is avoided by eliminating the addition of new salt and sodium hydroxide during the $\mathrm{Al}$ dissolution process. The cumulative IAS is realized through 2009 from Sludge Batches 3 , 4 and 5 . This idea should be relatively inexpensive to implement. New procedures and some minimal physical modifications to 
transfer routes may be required, depending on the source tank for the concentrated supernate. This idea results in similar space savings for all sludge batches requiring aluminum-dissolution through the entire life-cycle of the sludge processing program.

Risks associated with this idea are as follows:

- Tanks containing high hydroxide supernate may not be available when they are needed,

- Tank Farm infrastructure can not support needed transfers, and

- The amount of aluminum to be dissolved requires a longer period to process, thereby extending the time needed to prepare a sludge batch.

\section{- Install Telescoping Transfer Jets (TTJ) in Selected Tanks}

Some of the fixed height transfer jets are set too high and will not allow complete removal of supernate to enable full evaporation of existing waste. Because of this condition, several tanks contain supernate that has not been fully concentrated. For example, the existing fixed-height transfer jet in Tank 35 is at a level of 150 inches from the tank bottom. If a new TTJ were installed in Tank 35, up to an additional $300 \mathrm{~K}$-gal of space could be gained by evaporation of the additional supernate that could be removed from the tank.

In addition, installing a TTJ in each evaporator feed tank and each concentrate receipt tank may improve evaporator efficiency. By adjusting the height of the TTJ appropriately, evaporator feed could be drawn from the lower density supernate layers in tanks to promote higher space gain through improved evaporator efficiency. A combined chemistry and corrosion probe is also being developed for use in HLW tanks to enable real-time chemical analysis and on-line measurement of corrosion susceptibility. The prototype for this probe is planned for installation in FY00. If the probe is successfully demonstrated, it should provide the information needed to size the lengths of transfer jets to optimize evaporator operations.

The principal risk associated with this idea is difficulty (cost, radiation control concerns, etc.) in the removal and disposal of an existing jet and in the subsequent installation of a new TTJ in the required riser. These difficulties have been encountered with the installation of a new jet in Tank 8 for waste removal. 


\section{- Revise Tank Farm Waste Acceptance Criteria (WAC)}

This idea proposes to revise the Tank Farm WAC to eliminate or modify practices that can affect space negatively, especially excess caustic additions and dilutions imposed on NMSS waste receipts and DWPF recycle waste receipts. The Tank Farm WAC requires sufficient caustic to be added to NMSS waste to yield a neutralized solution containing at least 1.2 M excess caustic ( $\mathrm{NaOH})$. DWPF recycle waste must be neutralized to $0.5 \mathrm{M} \mathrm{NaOH}$. Caustic is added to the waste before it is transferred to assure the tank chemistry is not altered when the waste is added to a tank. Uncertainty related to splashing of waste on the walls above the liquid level and the inability to determine how well the new waste mixes with existing waste in the tank has led to these stringent specifications. Improved monitoring of tank chemistry (e.g. the combined chemistry and corrosion probe described above) may allow the concentration of inhibitors to be reduced in waste sent to the Tank Farm. Down-comers could also be installed to eliminate splashing and mixing concerns.

The risks associated with this idea include additional chemical monitoring requirements after a waste transfer. Additional metallurgical tests may also be required to assure that a reduction in the caustic concentration (or the concentration of other inhibitors) would not increase the risk of higher corrosion rates in the Tanks.

\section{- Implement Several Ideas to Reduce the volume of DWPF Recycle}

There are several ideas included in Table 6-3 that would reduce the volume of DWPF recycle waste sent to the Tank Farm. . Although the DWPF recycle stream has low salt concentration and can be easily evaporated, the inhibitors that must be added to this high volume stream to meet the Tank Farm WAC result in concentrate that eventually takes up space in the Tank Farm. Therefore, even small reductions in the total amount of DWPF recycle sent to the Tank Farm can result in space saved until an evaporator is installed in the DWPF to divert the recycle stream or salt processing is initiated.

The risks associated with these ideas include the costs, radiation concerns and remote replacement of equipment in an operating facility. These ideas requires new equipment to be purchased for various DWPF transfer pumps to reduce flushes, installation of a jumper in the Low Point Pump Pit to bypass the tank and eliminate multiple primes for each transfer and a reduction in the steam flow to the Melter Off-Gas system. The change to the Melter Off-Gas system will also require a test to confirm the required decontamination of the Melter off-gas is achieved at reduced steam flow to the scrubbers. 
- Reclaim Space in Tank $26 F$ by Placing the $2 F$ Evaporator in $\underline{\text { Standby }}$

Several conditions in the HLW System planning could lead to placing the 2F Evaporator in warm standby. These conditions include the following:

(1) The Replacement High Level Waste Evaporator is successfully started and operating as planned.

(2) The $2 \mathrm{H}$ evaporator continues to operate as planned.

(3) Salt space in Tank 46F is not needed to achieve the required IAS.

(4) Influents from F-Canyon processing do not increase significantly (beyond the forecast used as part of the basis for this study).

If all of these conditions are satisfied, then the $2 \mathrm{~F}$ Evaporator could be placed in warm standby. The remaining space in the $2 \mathrm{~F}$ Evaporator feed tank (26F) and the Evaporator receipt tank (46F) would then be available for storing concentrated supernate from $\mathrm{H}$ Area evaporators.

Before this idea can be implemented, all of the conditions listed above must be satisfied. The principal risk associated with this idea is that all conditions will not be satisfied before FY2010.

- Use Tank 23H and 24H for Storage of Spent Wash Water from ESP Processing

A significant volume of dilute wash water containing low concentrations of radionuclides is expected to be generated from ESP processing of Sludge slurry. Present plans to manage available space uses Type IV tanks in $\mathrm{H}$ Area (Tanks $21 \mathrm{H}$ and $22 \mathrm{H}$ ) to store DWPF recycle and/or spent wash water until it can be processed through an evaporator system. This idea proposes to also use Tanks $23 \mathrm{H}$ and $24 \mathrm{H}$ to store dilute waste. However, this idea would simply leave the waste in these two tanks until the Salt Processing Facility is operational. Use of these two tanks in this manner would be deferred until late in the time period of interest (beyond FY2006), receiving spent wash water from the preparation of Sludge Batches 4 and 5.

The principal risk associated with this idea is that the activity in this waste would be too high to allow overland transfer to these tanks from Tank 21 or Tank 22. If the activity is too high, then a valve box would have to be installed to handle the transfers. Using these tanks in this manner may also delay their retirement and closure. 


\section{Recover Tank 49 for High Level Waste Storage}

Tank 49 has about 100,000 gallons of High Level Waste containing a small amount of sodium tetraphenylborate (NaTPB) and associated decomposition products from the initial ITP demonstration run in 1984. In December 1998, during testing of the Distributive Control System, the tank ventilation system was secured to determine the rate of benzene generation in the Tank. A benzene generation rate that was greater than allowed within the approved facility authorization basis for air-based mode of operation was detected during this test.

The tank vapor space was converted to nitrogen-based operation (inert atmosphere). In accordance with the Justification for Continued Operations (JCO) that was issued, the waste is sampled and analyzed periodically to measure the rate of decomposition of the organic materials. The JCO requires the tank's vapor space to remain in nitrogen-based operation until such time the benzene generation rate has slowed to a rate that allows tank operations in an air-based mode.

\section{- Actions Needed to Recover Tank 49 for General HLW Storage}

The transition of Tank 49 to an air-based mode and subsequent conversion to general use for $\mathrm{HLW}$ storage requires these actions:

- Based on continued monitoring of the tank vapor space and waste solution, Tank 49 is projected to return to an air-based mode of operation around August 2000. The air-based mode of operation would require the facility to secure the use of the Nitrogen system and to operate the Tank's Ventilation system at $20.9 \%$ oxygen.

- Complete chemical and accident analyses to bound potential safety issues associated with slurry pump operations in Tank 49.

- Determine the impact of operation of the Tank Slurry Pumps on chemistry, and on the release of benzene.

- Complete chemical and accident analyses to bound the potential issues associated with slurry pump operations in Tank 49.

- Implement physical modifications if required to return Tank 49 to general HLW service. 
- Resolution of DNFSB Open Issues for Tank 49

The DNFSB identified several issues related to the ITP process. Because the concentration of NaTPB in Tank 49 waste is slowly decomposing, the applicable issues can be readily resolved to allow Tank 49 to be returned to general use for HLW storage. Of these issues, listed below, the last two (shown in italics) do not apply to Tank 49 since the waste in Tank 49 does not contain insoluble KTPB:

- Either establish a defensible bounding release rate for readily releasable benzene or install features that eliminate the safety concern.

- If avoiding the formation of readily releasable benzene is used as a basis for the Safety Strategy, the slurry pumps should be operated periodically to prevent the formation of a significant benzene layer.

- Demonstrate the ability to predict the threshold concentration of readily releasable benzene in the Tank.

- Reduce the uncertainty about how completely benzene can be depleted during slurry pump operation

- If Tank 49 material is transferred to Tank 50 and subsequently to $Z$ Area, then a defensible peak benzene generation rate must be used as the safety basis for Tank 50 and $\mathrm{Z}$ Area.

The Alternative Salt Project and previous DNFSB 96-1 chemistry tests have developed information needed to resolve these open issues for Tank 49 (and Tank 50; see Section 3.1.4 below). The required Chemistry development roadmap to reclaim Tank 49 for $\mathrm{HLW}$ storage is outlined in reference 18.

The required design and physical modifications to Tank 49 can be initiated in parallel with the resolution of the DNFSB items. Modifications were made at ITP to isolate Tank 49 from the HLW Storage and Transfer System to prevent the inadvertent transfer of TPB salts from the ITP process to the HLW Tank Farm. Two design changes for Tank 49 (M-DCP-96-081, "Modification to the Inter Area Transfer Line," and P-DCP-96-025, "Modifications to the leak detection box") were issued to provide the separation. A review to confirm slurry pumps and transfer pumps have adequate shielding and pumping capacity for HLW service must also be completed. The modifications that were made to the tank to support inerted operations will be required to remain in place since Tank 49 will be the emergency transfer tank for the material in Tank 48 . This includes the Nitrogen system, and vapor space monitoring for benzene and oxygen. 
The principal risk associated with Recovery of Tank 49 is that the forecasted TPB intermediates depletion rate and subsequent Benzene Generation Rate do not match the actual sample profiles. This could result in a slip of the forecasted date for the return of Tank 49 to HLW service.

\subsection{4}

\section{Recovery of Tank 50 for High Level Waste Storage}

Tank 50 is presently used as a receipt tank for ETF bottoms, an aqueous waste that is ready for final treatment and disposal as Saltstone. Based on current forecasts, Tank 50 will be filled in FY2004. Z Area must restart in FY2004 to process the waste stored in Tank 50 to prevent shutdown of ETF.

To reclaim Tank 50 for HLW storage, either continuous operation of $\mathrm{Z}$ Area is required or alternate storage and treatment is needed to eliminate transfer of ETF bottoms to Tank 50. Construction of a new storage tank for ETF bottoms (the idea selected for the Overall Strategy) has the lowest technical risk. Permitting issues should be minimal, since ETF bottoms contain very low concentrations of radioactive contaminants. In addition, shielding for the Tank 50 valve box, slurry pumps and transfer pumps must be evaluated.

The size of the new tank for ETF bottoms should be optimized to facilitate periodic transfers to the Saltstone Facility. It should also be sized to minimize the potential of an increase in the hazard classification of either ETF or Z area. The tank size could vary from 50,000 to 250,000 gallons and should be based on an optimization study. Construction of a new tank and modifying the transfer line from ETF to Z Area to bypass the Tank 50 valve box would eliminate the interfaces between Solid Waste operations in ETF and Z Area from the HLW Tank Farm. Presently, all transfers from ETF are directed through the Tank 50 valve box. This proposed modification would allow the ETF bottoms to be transferred directly from the ETF evaporator to the new tank and then from the new tank directly to $Z$ Area. By eliminating transfers through the Tank 50 valve box, transfers from ETF to Z Area do not have to be coordinated with HLW operations. This will allow HLW transfers to be made to Tank without impacting ETF or Z Area operations.

The principal risk associated with the Recovery of Tank 50 for HLW storage is that the new tank for ETF bottoms and transfer line modifications will not be completed by FY2004. This would require continued use of the Tank 50 valve box for transfers and continuing (intermittent) operation of $Z$ Area until the changes were complete. 
By diverting the DWPF recycle stream from the Tank Farm System, both a space gain and processing flexibility advantage can be realized for the Tank Farms. This waste stream can be eliminated by evaporating the unneutralized waste (acid evaporation).

The SM Team selected acid evaporation as the preferred process technology. The Salt Cell in the DWPF was selected for the location of the evaporator in preference to the Late Wash Facility (LWF). The SM Team chose the Salt Cell of the DWPF for three reasons: (1) This location would minimize transfers of radioactive materials outside the DWPF canyon. (2) the incorporation of evaporator bottoms into waste glass would be facilitated. (3) The LWF will likely be used as a pilot facility for the Salt Processing Facility (SPF), thereby avoiding additional cost for the location of a Pilot Plant.

If this evaporator is placed in the Salt Cell, space and equipment for the precipitate hydrolysis unit operations in the DWPF must be added to the ASPF Project. Other locations may provide better operation flexibility, without requiring a major modification to either the ASPF or the DWPF. The SM Team recommends a study be completed to optimize the location of an evaporator to handle DWPF aqueous waste. The principal uncertainty associated with this evaporator is how to handle the Evaporator bottoms. A preliminary review revealed several technical issues that could impact Melter operation, but the SM Team judged all of these issues could be resolved as part of the development of this process.

The project to design the evaporator should start in FY2001 so that it will be operational by FY2005. This time frame includes the location study, design, construction, equipment purchases and testing required to complete the proposed modifications to the DWPF.

There are several risks associated with this Idea. They include resolving design issues, chemical processing concerns, and the requirements to make modifications in an operating facility. The design of the evaporator system will require jumper modifications to be made throughout the DWPF Canyon. These jumpers would need to be capable of transferring aqueous waste to the Salt Cell from both the Melter Cell (Off-Gas Condensate Tank) and the Chemical Process Cell. The Distributive Control system must be modified to delete the Salt Cell operational controls and add in the controls for the new evaporator. Chemical processing concerns are associated with the Evaporator bottoms and the potential for build up of non-volatile salts that will not be compatible with the DWPF process and detrimental to Melter operations. 


\section{Reduce Emergency Space to $1300 \mathrm{kgal}$}

Recently, the Liquid Radioactive Waste Handling Facilities Safety Analysis Report (LRWHF SAR), WSRC -SA-33, was issued. The SM Team analyzed the long standing practice of maintaining 1.3 million gallons of emergency space in the H Area Tank Farm and the F Area Tank Farm (2.6 million gallons total). The LRWHF SAR specifies a defense in depth emergency space value for the Tank Farms equal to the largest tank inventory (1.3 million gallons). The use of the Inter-Area Line (IAL) would be required to reduce the Emergency Space to the minimum value of 1.3 million gallons.

This idea states that the minimum emergency space would be reduced incrementally from its current value of 2.6 million gallons, as required, to a level that could eventually drop to the Authorization Basis (AB) "defense- in-depth" value of 1.3 million gallons.

Though a viable idea, this idea should only be implemented near the end of the period before the start of Salt Processing because of the challenges it presents to operation of the Tank Farm. The SM Team identified several conditions that must be assessed before this idea is implemented. A prerequisite for reducing the Emergency Space would be to qualify IAL for emergency transfer readiness. Procedures must be written and upgrades made to the IAL to assure it is available at any time. The new procedures would require regular inspections and maintenance of equipment and instrumentation used for an emergency transfer so that this equipment is always available. The frequency of use of the IAL will increase significantly over the next few years as sludge slurry is sent to ESP and as backlog waste and wash water are sent to the $2 \mathrm{~F}$ evaporator. Experience gained from these transfers will provide a higher confidence in HLWD's ability to use the IAL for emergency transfers.

In addition to qualifying the IAL and related procedures for Emergency Transfers, the conditions listed below must be assessed for adverse operational impacts before Emergency Space is reduced. In particular, if conditions related to shutdown of the $2 \mathrm{~F}$ Evaporator are satisfied, then some of the risks associated with reducing Emergency Space, particular in F Area, are reduced.

(1) Complete evaporation of backlog waste currently stored in Tanks 30 , $32,35,39$ and 42 (from 40).

(2) Ensure RHLWE and $2 \mathrm{H}$ evaporators are in good operating condition.

(3) Assess planned processing plans and projected influent streams. If determined to be feasible, place $2 \mathrm{~F}$ evaporator in warm standby. 
(4) Use available space in the $2 \mathrm{~F}$ evaporator feed tank, Tank 26 , and concentrate receipt tank, Tank 46, for storage of concentrated supernate.

(5) Continue to assess other possible options for obtaining space.

(6) Based on planned processing and field conditions at the time, determine the amount of emergency space that should be maintained in each area and recommend the appropriate reduction from the 2.6 million gallons.

(7) Implement reduction in space reserved for emergency transfers.

(8) Repeat Steps 6-8, as required to meet space needs, until emergency space has been reduced to the minimum $\mathrm{AB}$ requirement of 1.3 million gallons.

\subsection{Overall Strategy Implementation}

The actions required to implement each idea are shown in Table 3-4. More specific changes needed to implement an idea were developed as part of the detailed costs, given in Reference 13. Further design and related cost estimates must be completed to provide budget-quality costs. 
Table 3-4: Actions Required to Implement Strategy

\begin{tabular}{|c|c|c|c|}
\hline \multirow[b]{2}{*}{ Ideas \& Project Descriptions Included in Overall Strategy } & \multicolumn{2}{|c|}{ Project Schedule } & \multirow{2}{*}{$\begin{array}{c}\text { Total } \\
\text { Project } \\
\text { Cost, M\$ }\end{array}$} \\
\hline & Start & Finish & \\
\hline $\begin{array}{l}\text { Continue to Evaporate Waste } \\
\text { - No physical modifications } \\
\text { - Radioactive Startup of the Replacement HLW Evaporator }\end{array}$ & NA & NA & NA \\
\hline $\begin{array}{l}\text { Recover \& Reuse Tank } 49 \\
\text { - Piping modifications }\end{array}$ & 2000 & 2001 & 2.0 \\
\hline $\begin{array}{l}\text { Eliminate DWPF Recycle to HLW Tank Farm by Acid } \\
\text { Evaporation of DWPF Recycle in Salt Cell } \\
\text { - Remove existing equipment and install a remotable } \\
\text { evaporator } \\
\text { - Modify piping as needed in DWPF } \\
\text { - Provide piping from OWST to H-Area Process Sewer } \\
\text { - Rework DWPF control instrumentation to } \\
\text { accommodate evaporator \& reprogram PCS software }\end{array}$ & 2001 & 2004 & 28.2 \\
\hline $\begin{array}{l}\text { Return Tank } 50 \text { to HLW Service By Installing a New Tank } \\
\text { for Receipt, Storage and Transfer of ETF Bottoms to Z Area } \\
\text { - Construct new ETF bottoms tank } \\
\text { - Modify transfer line from ETF to Z Area via the new } \\
\text { tank } \\
\text { - Upgrade shielding on Tank } 50 \text { \& piping to enable its } \\
\text { use in HLW operations }\end{array}$ & 2001 & 2004 & 28.8 \\
\hline $\begin{array}{l}\text { Implement Small Volume Gain Initiatives } \\
\text { - Modify piping } \\
\text { - Upgrade documentation }\end{array}$ & 2000 & 2003 & 1.4 \\
\hline $\begin{array}{l}\text { Reduce } 2.6 \mathrm{M} \text {-gals Emergency Space to } 1.3 \mathrm{M} \text {-gal (AB } \\
\text { Limit) } \\
\text { - Modify piping } \\
\text { - Install } 4 \text { transfer pumps ( } 2 \text { in each Area) } \\
\text { - Modify infrastructure for inter-area transfer line }\end{array}$ & 2006 & 2007 & 9.6 \\
\hline Total TPC & & & $\mathbf{7 0 . 0}$ \\
\hline
\end{tabular}


- Regulatory Issues

The Overall Strategy requires minimal regulatory changes. The Industrial Waste Water Treatment permit for ETF Bottoms will require changing but this is expected to be a minor action. At the present time, the IWWT Permit defines the path for ETF bottoms to be through Tank 50, where the waste is stored until it can be transferred to Z Area for treatment and disposal. The change proposed will install a new staging tank and modify the transfer line to separate the system from Tank 50 .

\section{- Resolution of DNFSB Issues}

Several of the ideas require DNFSB review and acceptance that the safety risks are adequately addressed and present minimal risk to the workers and the public. These include: 1) the determination that the benzene potential has been reduced to controllable levels before Tank 49 can be emptied and reclaimed for reuse; 2) flammable gasses (i.e., ammonium nitrate) are prevented or controlled in the acid evaporation of the DWPF recycle; and 3) no undue risks are encountered by implementing the Small Volume Gain Initiatives.

\section{- Implementation Schedule}

The projected start date for the implementation of each idea is critical to the Overall Strategy. As shown in Table 3-1, each Idea has a Date that reflects when work to implement an idea must begin to realize the volume gain to meet the ASB. The deferral in reducing Emergency Space until as late as possible is contingent on two key assumptions: (1) ideas are implemented according to the proposed schedule and (2) the SVGI achieve their projected volumes. The TIAS for each Idea and the Small volume gains were calculated on a best estimate basis and are believed to be somewhat optimistic.

Either reducing Emergency Space sooner or adding another Idea not included in the Overall Strategy should be evaluated if any one idea in the Overall Strategy is delayed or the actual space gain is significantly less than projected. 


\subsection{Strategy Costs}

The Life cycle costs (in FY1999 dollars) for various elements of the Overall Strategy are shown in Table 3-4. The incremental difference in costs was determined relative to Planning Case in Revision 10 of the HLW System plan. ${ }^{19}$ That is, the cost of a recommended Idea is represented as a delta relative to the costs outlined in the FY1999 Planning Case Budget. Life Cycle Costs were estimated since an idea that offers near-term benefits in cash flow and budget could be vastly over-shadowed by Life Cycle Costs. An example of an idea that has near-term benefits but a high Life Cycle Cost is the Idea of Shutting Down the DWPF. Over the next nine years there would be relatively large savings since there is a reduction in material costs, staffing, and maintenance costs associated with the operation of DWPF. However, from a Life Cycle perspective there is a dramatic impact on cost. The increase in Life Cycle coșt is because every year that DWPF is not operating, the HLW system operating life is extended by one year and annually adds $\$ 400$ million to cover the HLW Division's operating cost. Table 3-6 summarizes the near term costs for each Idea in the Overall Strategy. The Ideas with a cost increase from the short-term costs to Life Cycle Costs are the Tank 50 ETF bottoms tank and the DWPF Acid Evaporator. These are two new processes that would have increased operations and maintenance costs in the years subsequent to FY2009. The other Ideas are items that have a short-term implementation and operation phase. The Backlog Evaporation, Small Volume Space Gains, and returning Tank 49 to $\mathrm{HLW}$ service are all near term items and have the costs associated with it included in the HLW FY99 budget.

Table 3-5: Strategy Life Cycle Costs (Cost in Millions of \$)

\begin{tabular}{|l|l|l|l|l|}
\hline \multicolumn{1}{|c|}{ Ideas } & $\begin{array}{r}\text { Total } \\
\text { Project } \\
\text { Costs }\end{array}$ & \multicolumn{1}{|c|}{$\begin{array}{c}\text { Operating } \\
\text { Cost }\end{array}$} & $\begin{array}{l}\text { D\&D } \\
\text { Costs }\end{array}$ & Total LCC \\
\hline Continue to Evaporate Waste & 0 & 8.0 & 0 & 8.0 \\
\hline Recover \& Reuse Tank 49 & 2.0 & -0.6 & 0 & 1.4 \\
\hline $\begin{array}{l}\text { Eliminate DWPF Recycle to HLW Tank Farm } \\
\text { by Acid Evaporation of DWPF Recycle in Salt } \\
\text { Cell }\end{array}$ & 28.2 & 9.2 & 0 & 37.4 \\
\hline $\begin{array}{l}\text { Returm Tank 50 to HLW Service By Installing } \\
\text { New Tank for Staging of ETF Bottoms for Z } \\
\text { Area }\end{array}$ & 28.8 & -8.0 & 10 & 30.8 \\
\hline Implement Small Volume Gain Initiatives & 1 & 1.4 & 0 & 2.4 \\
\hline $\begin{array}{l}\text { Reduce 2.6 M-gals Emergency Space to 1.3 } \\
\text { M-gal (AB Limit) }\end{array}$ & 9.6 & 0 & 0 & 9.6 \\
\hline
\end{tabular}


Table 3-6: Idea Costs Between 2000 and 2009 (Costs in Millions)

\begin{tabular}{|l|l|l|l|l|l|}
\hline \multicolumn{1}{|c|}{ Idea } & $\begin{array}{c}\text { Total } \\
\text { Estd. } \\
\text { Cost } \\
\text { (TEC) }\end{array}$ & $\begin{array}{c}\text { Other } \\
\text { Project } \\
\text { Costs } \\
\text { (OPC) }\end{array}$ & $\begin{array}{c}\text { Total } \\
\text { Project } \\
\text { Cost } \\
\text { (TPC) }\end{array}$ & $\begin{array}{c}\text { Operational } \\
\text { Cost }\end{array}$ & $\begin{array}{c}\text { Total } \\
\text { Costs }\end{array}$ \\
\hline Continue to Evaporate Waste & 0 & 0 & 0 & 8.0 & 8.0 \\
\hline Recover \& Reuse Tank 49 & 1.3 & 0.7 & 2.0 & -0.6 & 1.4 \\
\hline $\begin{array}{l}\text { Eliminate DWPF Recycle to HLW } \\
\text { Tank Farm by Acid Evaporation of } \\
\text { DWPF Recycle in Salt Cell }\end{array}$ & 18.0 & 10.2 & 28.2 & 2.4 & 30.6 \\
\hline $\begin{array}{l}\text { Return Tank 50 to HLW Service } \\
\text { By Installing New Tank for Staging of } \\
\text { ETF Bottoms for Z Area }\end{array}$ & 21.0 & 7.8 & 28.8 & -8.0 & 20.8 \\
\hline $\begin{array}{l}\text { Implement Small Volume Gain } \\
\text { Initiatives }\end{array}$ & 1.0 & 0.4 & 1.4 & 1.0 & 2.4 \\
\hline $\begin{array}{l}\text { Reduce 2.6 M-gals Emergency Space } \\
\text { to 1.3 M-gal (AB Limit) }\end{array}$ & 7.0 & 2.6 & 9.6 & 0 & 9.6 \\
\hline
\end{tabular}

\subsection{Strategy Sensitivities}

The SM Team Overall Strategy has several sensitivities to cost, schedule and Stakeholder issues. The most sensitive issue in the Overall Strategy is the FY 2000 date associated with the start of the Project for the Proposed Salt Processing Facility. Any delay in the start date for this proposed Project would require a separate major project to be initiated to construct New HLW Tanks. A delay would also likely require Old Tanks to be reused to provide space until either the New Tanks are available for use or the Salt Processing Facility is operational.

The cash flow profile shown in Figure 3-2 shows that the Overall Strategy approximately matches the cash flow profile for the FY1999 planning case. The near-term impact on cash flow and budget constraints is minor compared to the unfavorable impact that a Capital Project such as building New Tanks would impose.

The Overall Strategy is sensitive to new missions and DWPF production rates. The potential for an increase in $\mathrm{F}$ and $\mathrm{H}$ Canyon production has some impact on the ability of the Overall Strategy to meet the required IAS. Presently the Canyon's effluent comprises approximately 10 percent of the total Waste Management Division waste receipts. Therefore, any new missions must be evaluated for projected waste volume sent to the Tank Farms to establish their potential impact on available space. 
DWPF canister production is also a critical parameter. An increase in production rate increases the volume of DWPF recycle waste and also increases the volume of spent wash water from ESP. The logistical difficulties of handling large volumes of dilute waste will likely prevent the Tank Farm and ESP from supporting a sustained canister production rate beyond the level of 200 canisters per year assumed in this study. Significantly higher rates must be deferred until the Salt Processing Facility is operational.

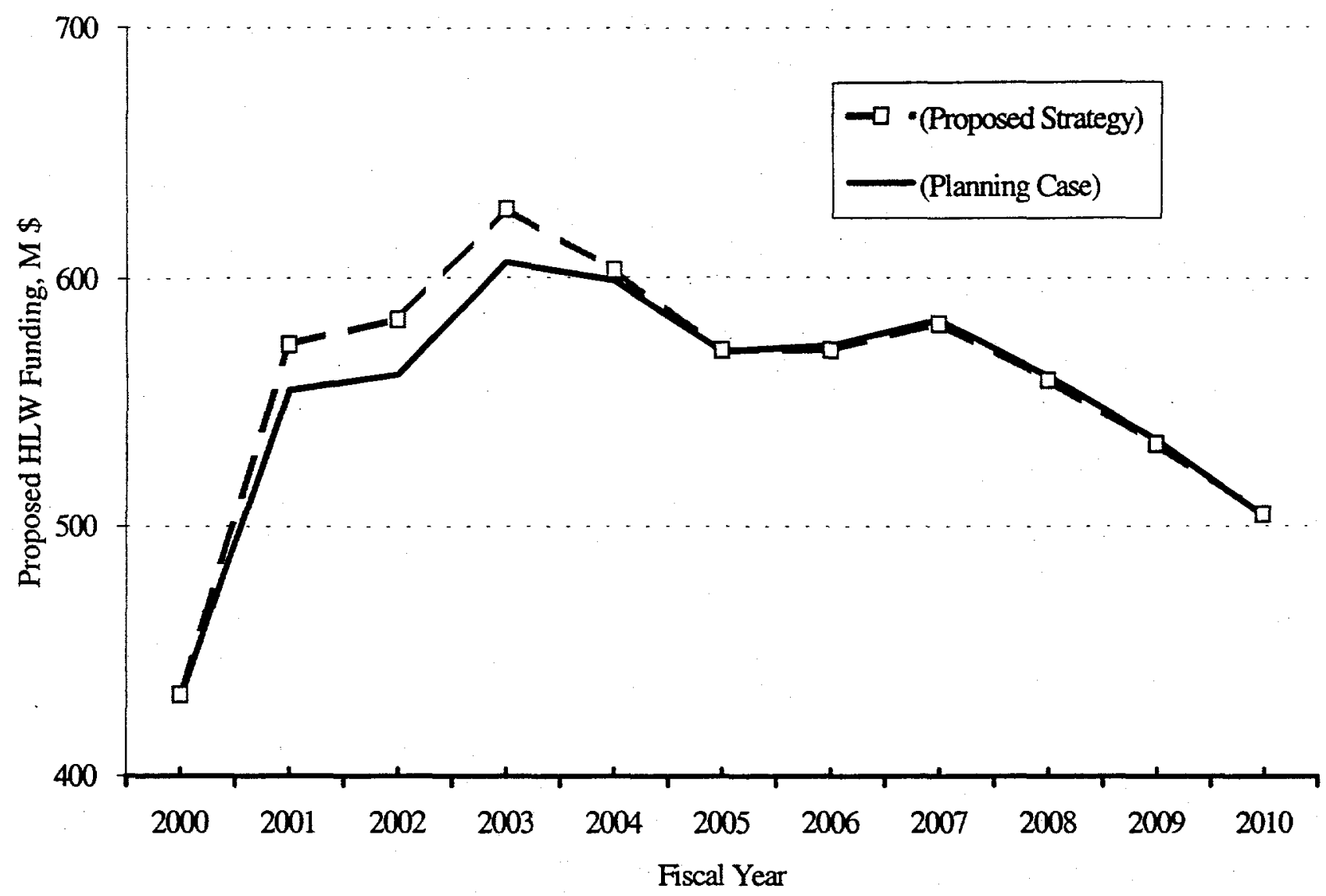

Figure 3-2: Impact of Overall Strategy on Proposed HLWD Funding (Basis: Planning Case in Rev. 10 of the HLW System Plan ${ }^{19}$ ) 


\subsection{Systems Engineering Process}

This section defines processes the SM Team used to objectively and efficiently complete its chartered activities. The process provided steps to develop the relevant information and activities needed for SM Team. The SM Team utilized a SE process. The SE approach is instrumental in managing large and technically complex projects and is recognized by both the DOE and DNFSB as an effective methodology for project development. DOE Order 430.1 (Life Cycle Asset Management LCAM) and the associated Good Practice Guides outline the principles and practices of Systems Engineering, as well as WSRC guidance documents and procedures.

The SE process requires the identification of appropriate personnel and resources to perform mission definition and analysis, functions and requirements analysis, strategy evaluation, risk management, integration \& planning, selection, validation, and verification. The Systems Engineering Management Plan (SEMP) ${ }^{3}$ describes the SE process and methodology. The hierarchical relationship of the SEMP ${ }^{3}$ to other SM Team documents is shown in Figure 4-1.

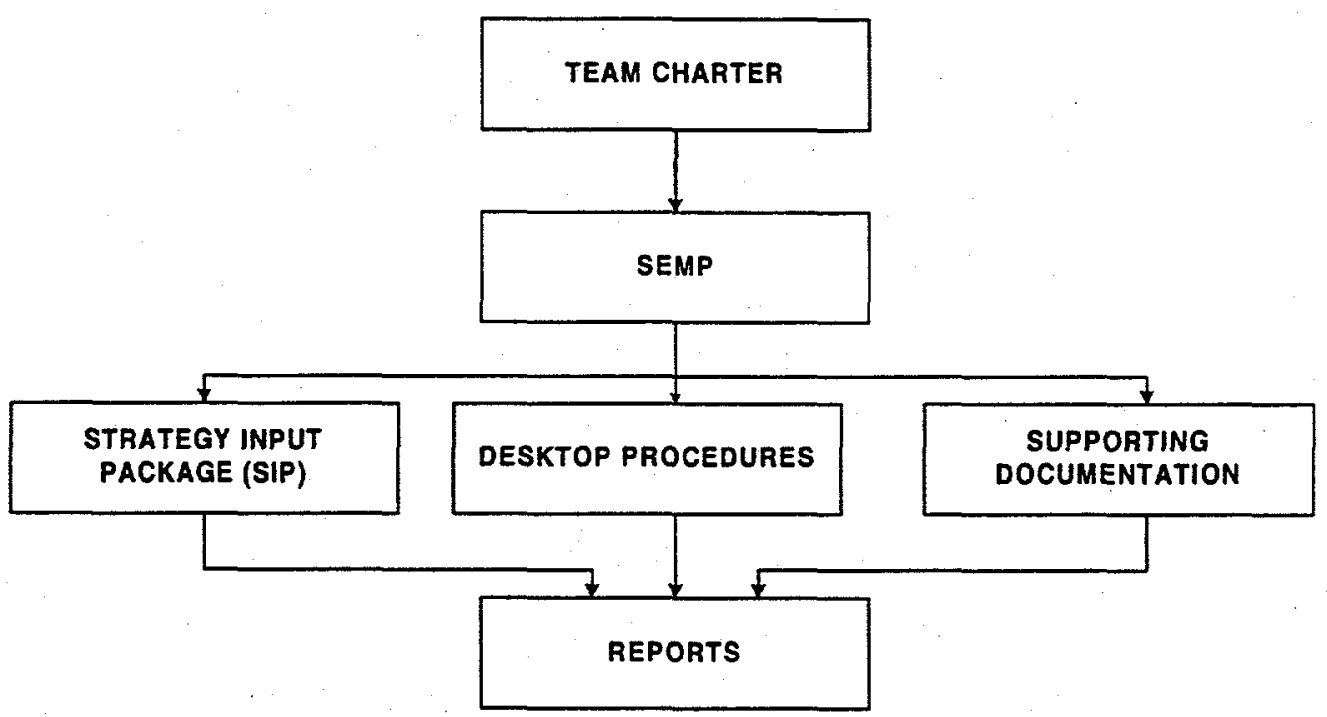

Figure 4-1: Hierarchical Relationship of the SEMP to Other SM Team Documents

The process utilized in developing ideas and ultimately a preferred strategy for tank space until 2009 evolved in three phases. These phases are referred to as Identification, Evaluation, and Selection. The major activities and outputs of each phase are illustrated in Figure 4-2. 


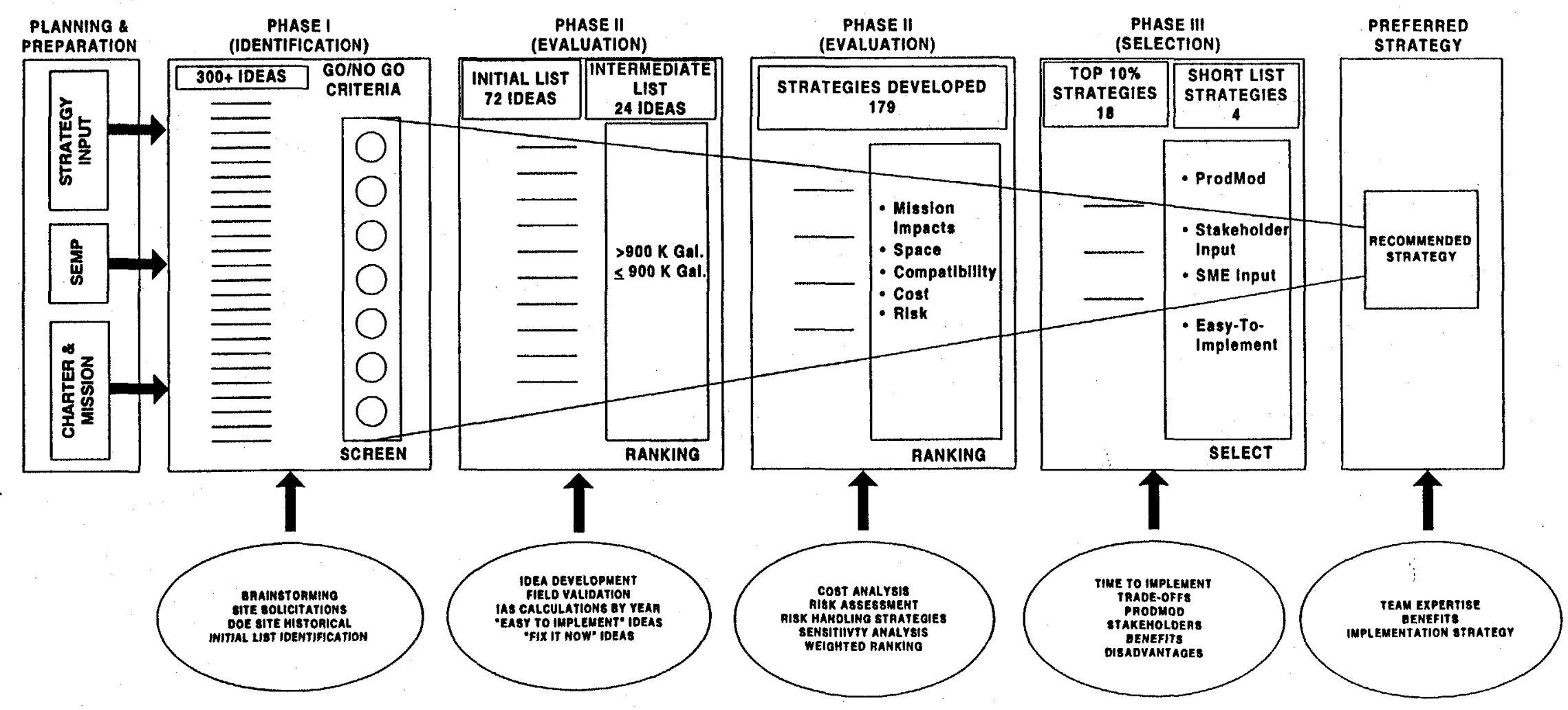

Figure 4-2: System Engineering Process for Strategy Selection 


\subsection{Identification Phase}

During the Identification Phase, the SM Team developed a logic-tied schedule of tasks required to complete the scope of the charter. The principles and practices identified in the SEMP $^{3}$ were then implemented in the required procedures, position papers, and reports were developed to document the structured controls, inputs, support resources needed, and outputs obtained during the SM Teams activities. This is illustrated in Figure 4-3. This phase focused on applying the SE process in the development of problem definition, top level mission analysis, the necessary and sufficient functions, requirements and interfaces, that a successful Strategy must satisfy, key assumptions, and definitions of terms.

Several systems engineering process tools were used to systematically identify a broad and comprehensive list of diverse ideas and Strategies for subsequent Evaluation and Selection. The methods used included brainstorming by subject matter experts/stakeholders and solicitation of SRS employee input. Models were developed to facilitate brainstorming of ideas. The results of the Identification Phase culminated in the Initial List ${ }^{8}$ of ideas, which are discussed in detail in Section 6.0 (Idea Identification). 


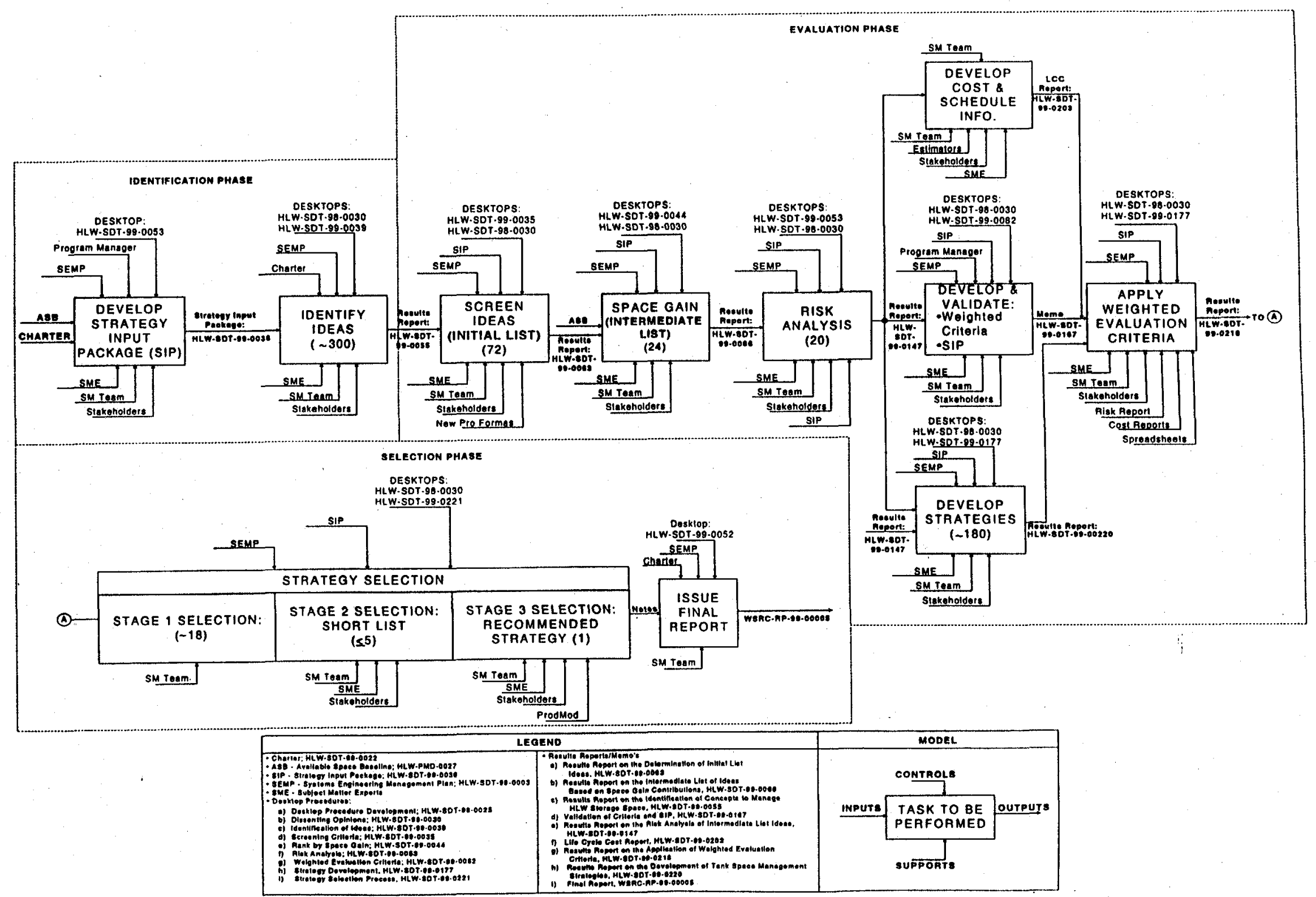

Figure 4-3: HLW Tank Space Management Strategy Development Business Model 


\subsection{Evaluation Phase}

The Evaluation Phase included screening ideas and Strategies, assessing space gain, perform risk analysis, developing cost and schedule information, validation of selection criteria, developing strategies, and applying the weighted evaluation criteria.

High risks were assigned risk handling strategies. In addition, the SM Team conducted a field trip to the AGNS Facility in Barnwell, S.C. for the purpose of validating the risks identified and process applied since this was an "offsite" facility. The details and results of the preliminary risk assessment activities are discussed in Section 8.0 (Strategy Development).

The Evaluation Phase began with a detailed review of the Initial List ${ }^{8}$ to further downselect to an Intermediate List ${ }^{9}$. This systematic evaluation consisted of defining key evaluation criteria with assigned weights. Each weighted criterion was supplemented by "utility functions". The utility functions provide a means of consistently evaluating the alternatives against each criterion to yield numerical scores for comparison purposes.

To complete the Evaluation Phase, the SM Team considered the weighted scores, technical information, and risk results to derive the Short List of alternatives.

\subsection{Selection Phase}

The Selection Phase was structured to facilitate the SM Team's selection of a preferred tank space management Strategy. The results of the ranking by weighted criteria, along with inputs by subject matter experts and stakeholders was augmented by a qualitative evaluation based on SM Team expertise of each of the Short List alternatives. The qualitative evaluation considered the strengths and weakness of each Strategy which concluded with the selection of a preferred Strategy. The Selection Phase is discussed in more detail in Section 9.0 (Strategy Down-Selection). 


\subsection{Strategy Input}

This section describes the inputs, controls, supporting resources, and outputs developed by the SM Team for producing the Strategy Input.

Before the SM Team could begin to identify candidate Strategies for HLW tank space management, the requirements and constraints which a successful Strategy must accommodate needed to be defined. This is referred to as "Strategy Input", and was considered part of the Identification Phase.

The initial step in the process of recommending a HLW tank space management Strategy, was to define the expectations, characteristics, and attributes of a successful Strategy. Strategy Input is the definition of functionality and performance that the recommended Strategy must satisfy, as well as the bases for these expectations.

Figure 5-1 below depicts the model used for development of the Strategy Input Package 5 .

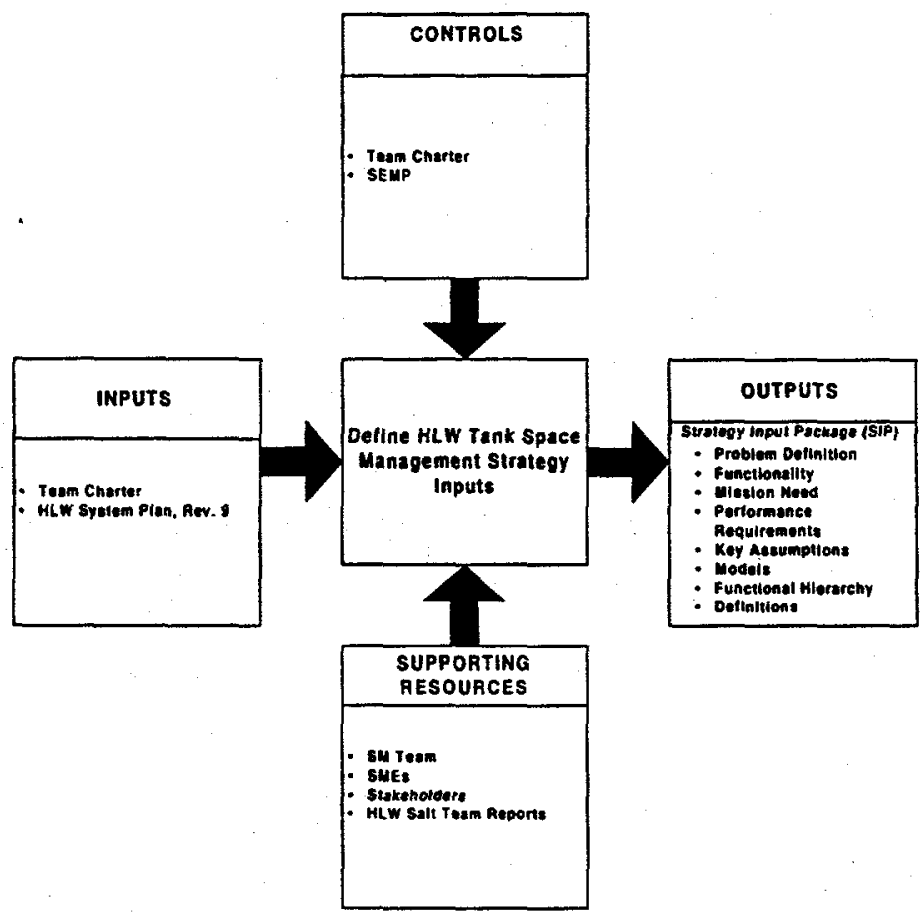

Figure 5-1: Model Depicting Strategy Input Development 


\subsection{Problem Definition}

The SM Team defined the fundamental problem, which the recommended tank space management Strategy must address, as:

"The tank space management strategy in the HLW System Plan (Revision 9) ${ }^{1}$ is no longer adequate as a result of the delay in HLW Salt Processing".

The basis for this definition is the SM Charter ${ }^{2}$.

\subsection{Mission Need}

The primary mission need to be fulfilled by the recommended HLW tank space management Strategy is defined as:

"Manage HLW storage space to minimize restrictions on SRS missions".

The basis for this resides in the SM Team Charter ${ }^{2}$.

\subsection{Key Assumptions}

The SM Team found it necessary to identify global assumptions to facilitate the identification, evaluation, and selection of a HLW tanks space management Strategy. As can be expected when searching a long term, multi-faceted solution, such as the task at hand, uncertainties exist. To address these unknowns, the SM Team identified key assumptions. The SM Team made every effort to minimize the number of key assumptions to impose on potential Strategies. The key assumption defined in the SM Team Charter ${ }^{2}$ is:

"No HLW Salt Disposition process is available to begin operation until 2009".

The additional key assumptions defined by the SM Team are:

- DOE will remain the primary regulator of $H L W$ at SRS.

- Existing and new HLW facilities will continue to be permitted as Industrial Waste Water Facilities.

- Current requirements are open to challenge.

- Influent streams will be no greater than forecasted. 
- No "emergency" influents from other facilities (e.g., tritiated water from reactor basins) is assumed.

- There will be no tank leaks requiring use of emergericy space.

- Trucked waste and $299 \mathrm{H}$ waste quantities are considered negligible for strategy development.

- The composition and volumes of existing tank farm inventory is per the Waste Characterization System (WCS), dated 1/22/99.

- Space in tanks $17 \& 20$ will not be reclaimed because the tanks are closed.

\section{$5.4 \quad$ Functionality}

The recommended Strategy must be capable of performing certain necessary and sufficient functions. A function is simply a statement of "what the Strategy must do". Due to the nature and complexity of managing $\mathrm{HLW}$, the Strategy has several functions which must be accomplished in order to provide safe and cost effective operations within the tank farms. The SM Team developed the functionality in "layers". The mission need defined in section 5.2 was used as the overall top level function which must be satisfied. Lower levels of functions were also developed. Figure 5-2 illustrates the functional hierarchy at the top two levels.

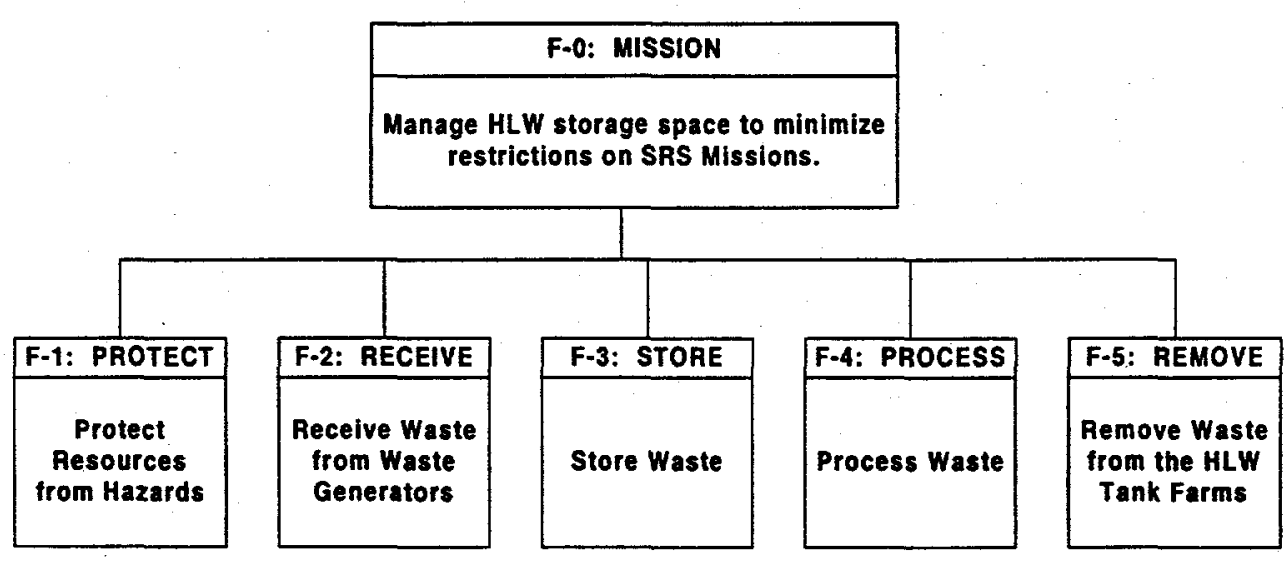

Figure 5-2: HLW Tank Space Management Strategy Top Level Functional Hierarchy 
The functional relationship of the top level functions is depicted in Figure $5-3$ in a functional flow diagram. This figure indicates the inputs and outputs of each function with respect to the others.

F-0: STRATEGY MISSION

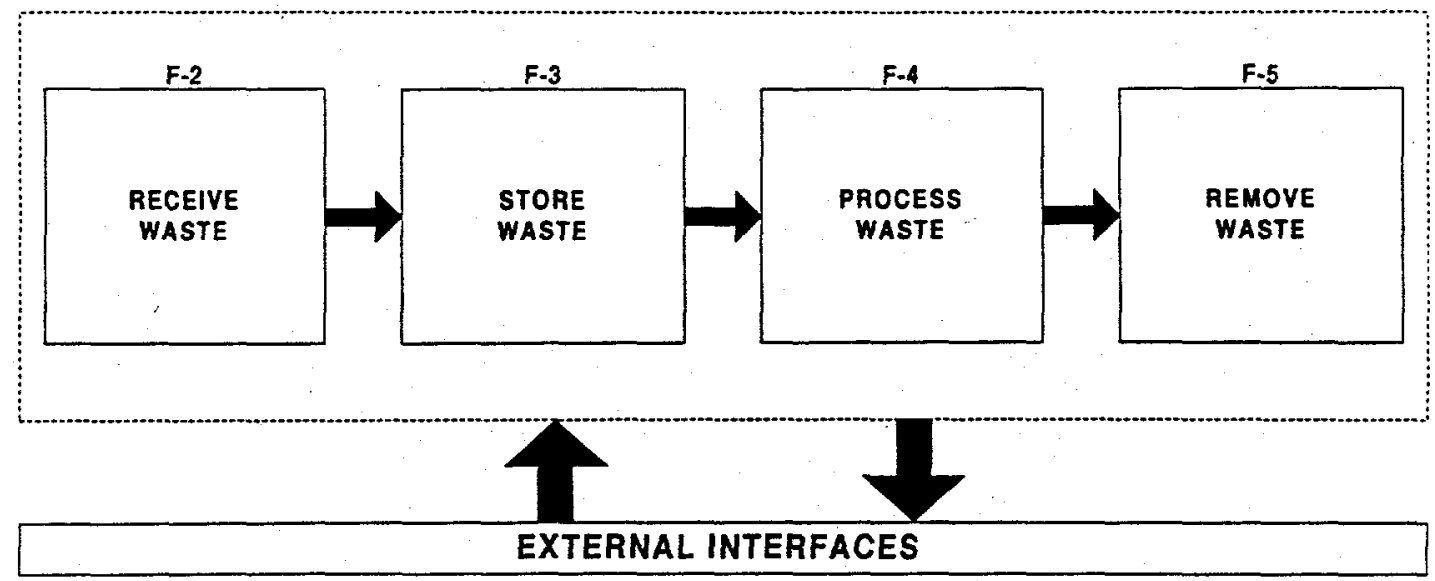

Figure 5-3: HLW Tank Space Management Strategy Functional Flow

The detailed HLW tank space management Strategy functional hierarchy is depicted in Figure 5-4. 


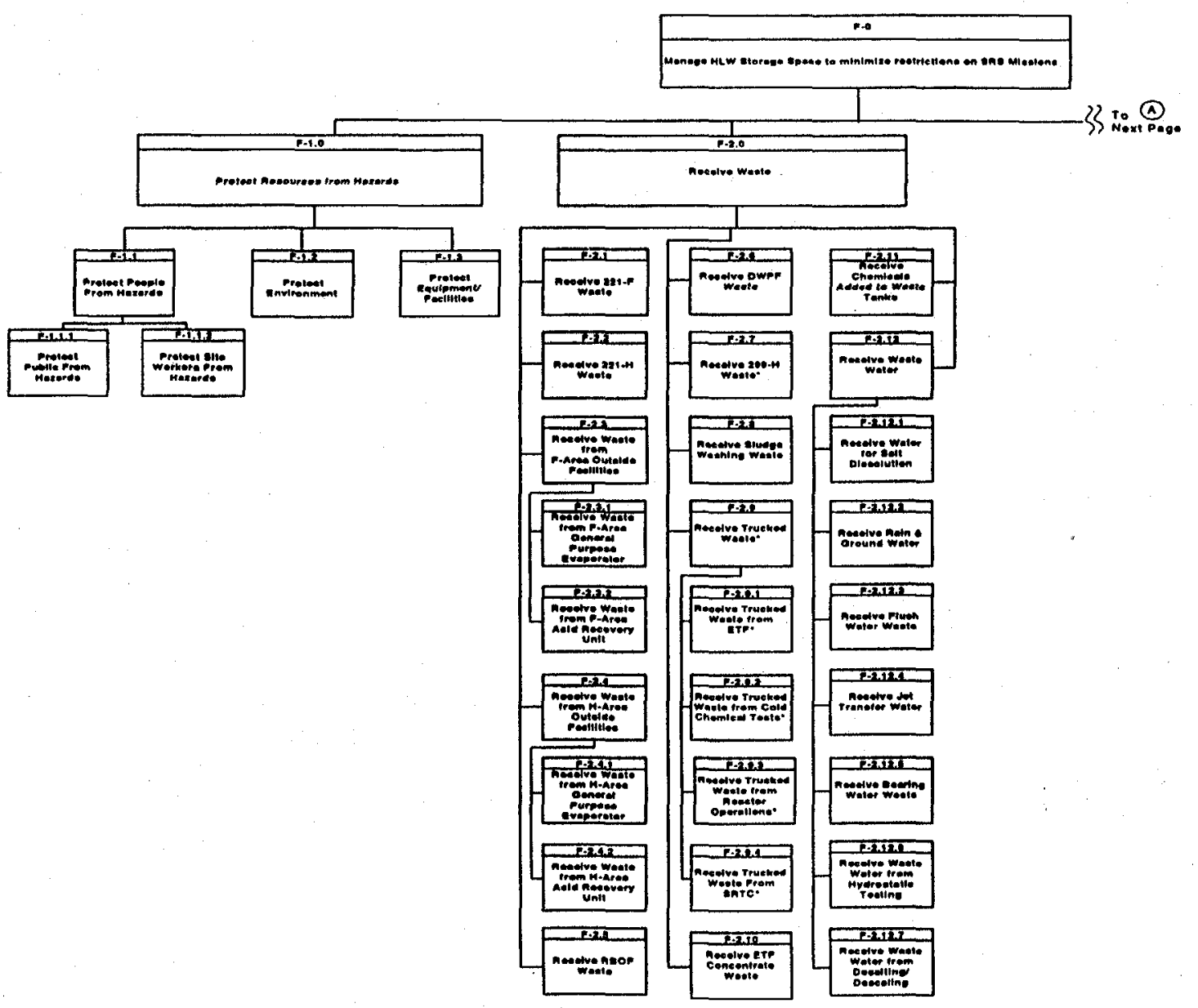

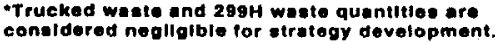

Figure 5-4: Detailed Functional Hierarchy for HLW Tank Space Management Strategy (Page 1 of 3) 


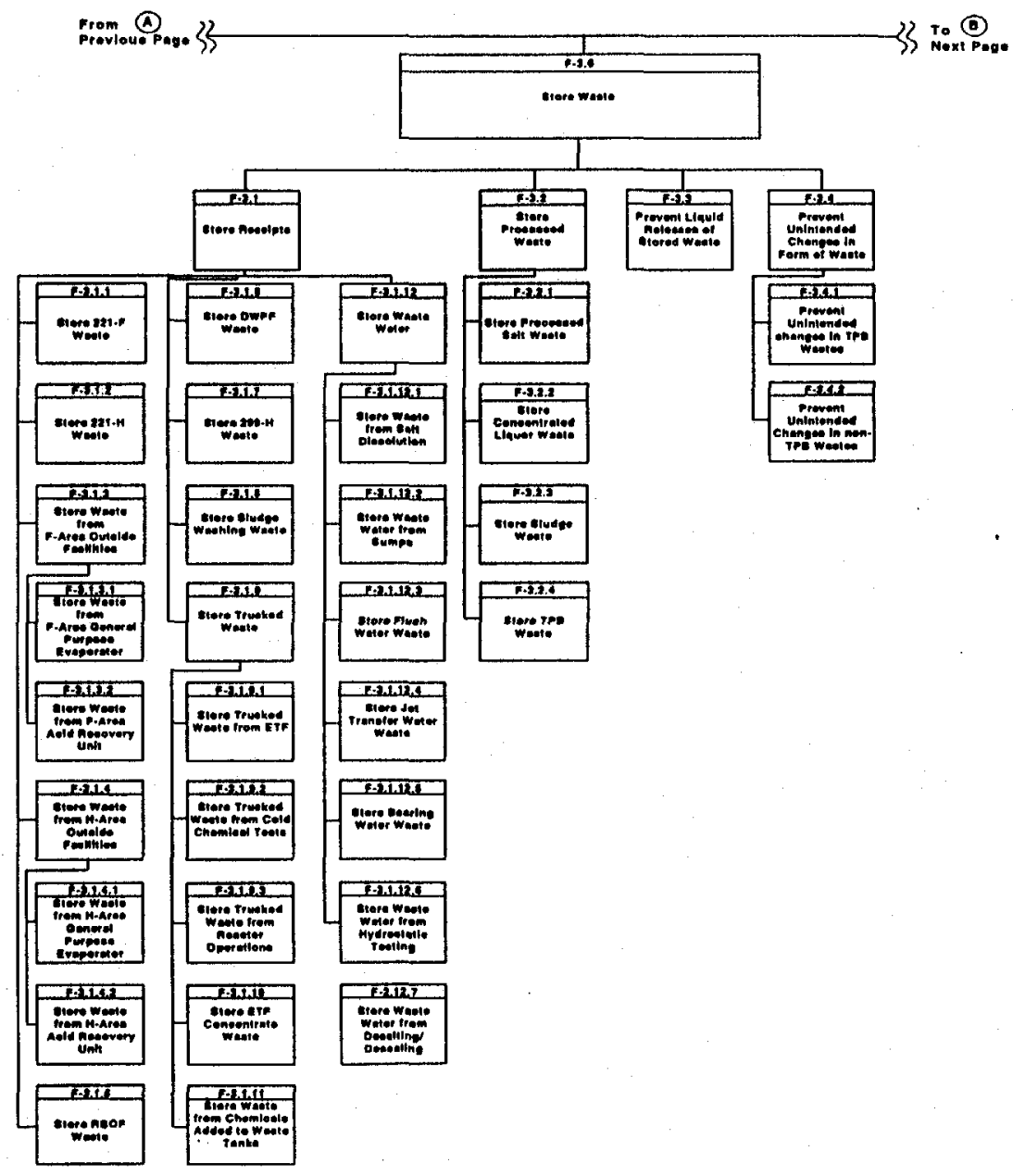

Figure 5-4: Detailed Functional Hierarchy for HLW Tank Space Management Strategy (Cont.) (Page 2 of 3) 


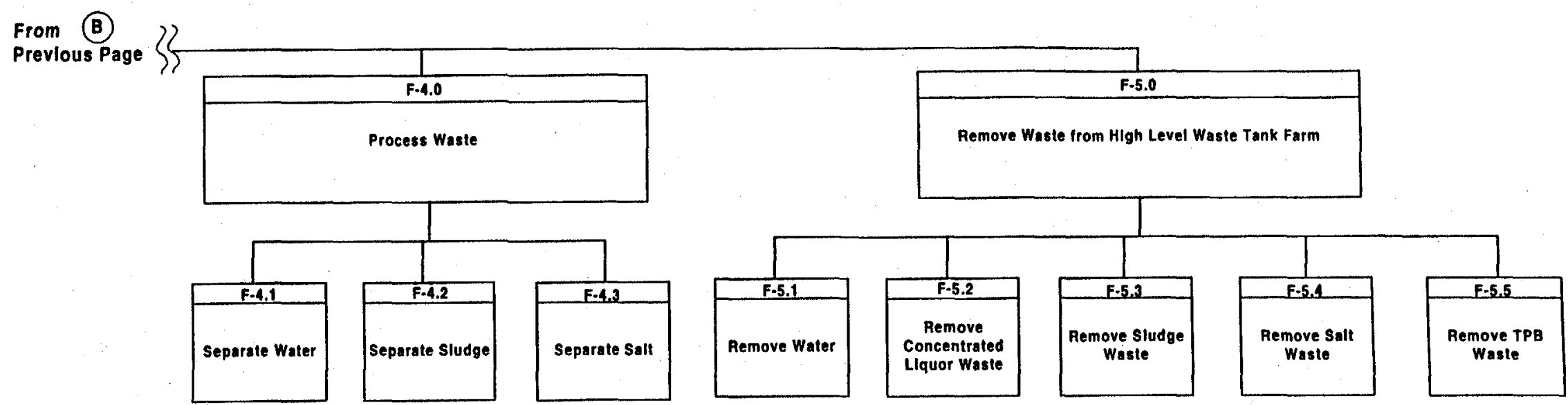

Figure 5-4: Detailed Functional Hierarchy for HLW Tank Space Management Strategy (Cont.) (Page 3 of 3) 


\subsection{Requirements}

The necessary and sufficient performance requirements were determined and allocated to the appropriate function(s) discussed in Section 5.4. Requirements determining "how well" a function must perform and/or the constraints and interfaces which must be observed. The requirements assigned to the mission level function are provided below. The requirements associated with the second and lower level functions are numerous and are contained in the SIP. $^{5}$.

\section{MISSION FUNCTION LEVELO}

F-0: $\quad$ Manage HLW storage space to minimize restrictions on SRS missions.

\section{MISSION REOUIREMENTS LEVELO}

The function described in F-O above:

R-0-1: $\quad$ Shall meet applicable federal, state, and SRS safety requirements.

R-0-2: $\quad$ Shall meet applicable federal, state, and SRS environmental regulations.

R-0-3: $\quad$ Shall meet applicable facility Waste Acceptance Requirements.

R-0-4: $\quad$ Shall meet applicable Federal Facility Agreements (FFA) and Site Treatment Plan (STP) commitments.

R-0-5: $\quad$ Shall accommodate other SRS missions and associated schedules.

R-0-6: $\quad$ Shall have the minimum evaluated combination of programmatic and technical risk and life cycle cost.

R-0-7: $\quad$ Shall provide emergency tank space per Operational Safety Requirement (OSR 1-1).

R-0-8: $\quad$ Shall maintain long term blending strategies for the Small Tank TPB, CST Non-Elutable Ion Exchange, and Direct Disposal in Grout alternatives.

R-0-9: Shall only utilize demonstrated technologies.

R-0-10: Shall implement proposed changes to existing requirements only after evaluation for stakeholder acceptability.

R-0-11: Shall maintain costs within SRS Environmental Management (EM) Funding Profiles.

R-0-12: Shall provide storage space for HLW, at least through 2009, to offset the projected deficit in available space. 


\section{$5.6 \quad$ Models}

The SM Team developed an administrative solution model and a universal flow sheet model to facilitate physical representations of the functions to be performed. These models are described below.

\subsubsection{Administrative Model}

The functions to be performed by the recommended HLW tank space management Strategy can only be achieved in four general modes referred to as, 1) decrease or delay incoming; 2) increase outgoing material; 3) compress material; or 4) increase available space. This model is represented in Figure 5-5.

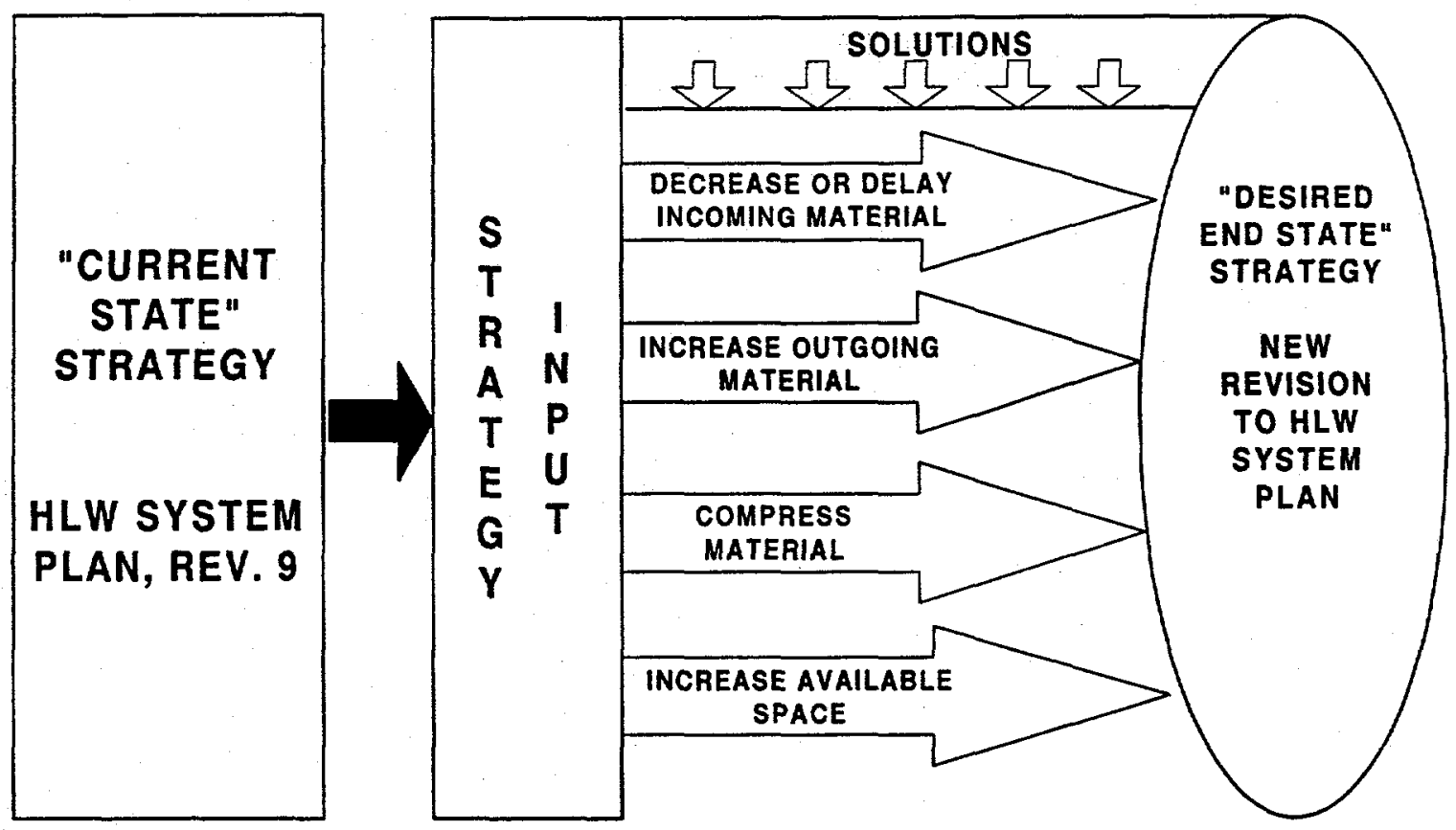

Figure 5-5: HLW Tank Space Management Strategy Administrative Solution Model

\subsubsection{Universal Model}

The flow of material within, or out of, the HLW system can be described in generic flowpaths as shown in Figure 5-6. Note that the shaded box, which represents the alternative salt disposition proposed project, is not within the chartered activities of the SM Team. It is shown to illustrate the relationship between the SM Team activities and those of the sponsoring HLW Salt Disposition Systems Engineering Team. 

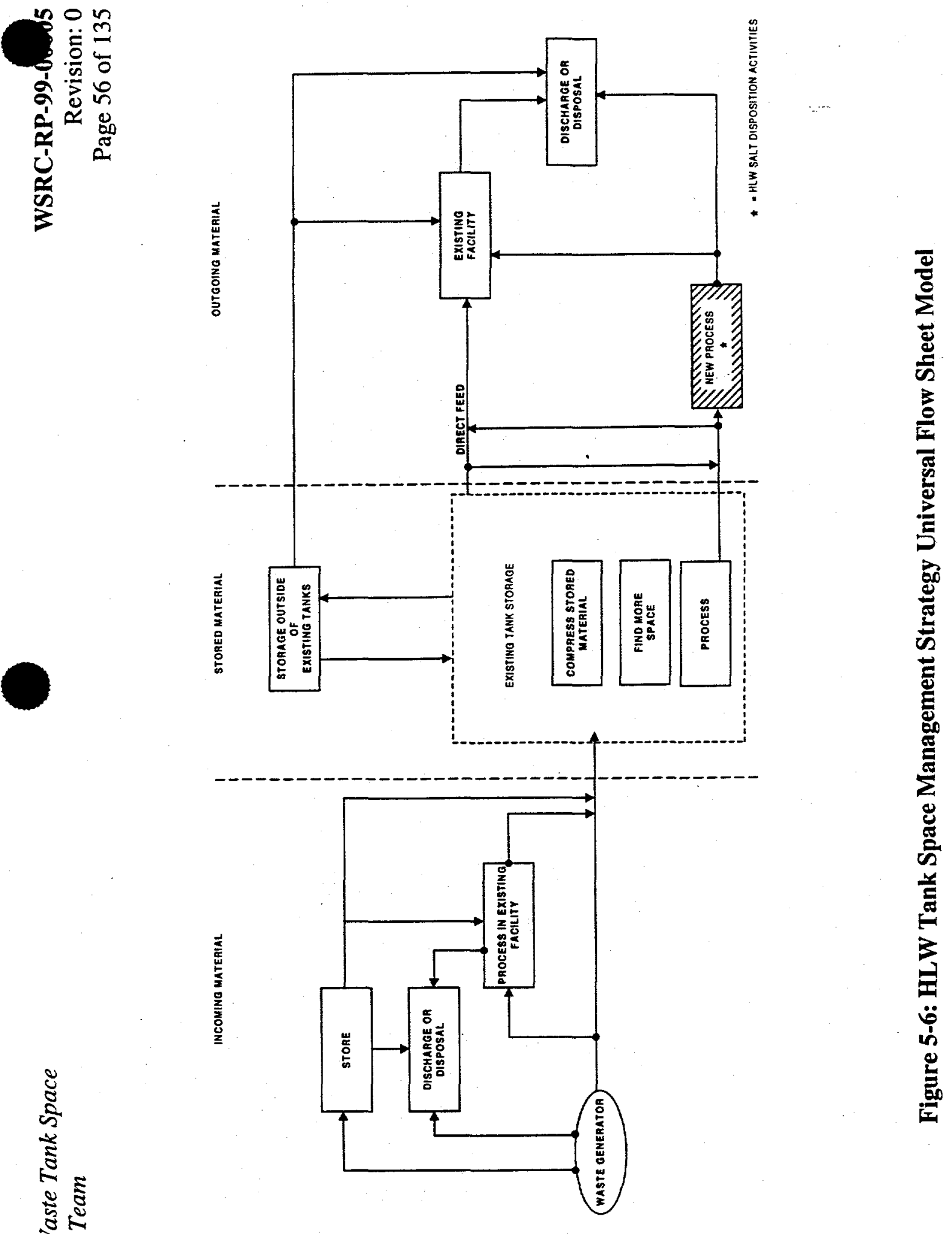


\section{$5.7 \quad$ Validation}

SM Team methods of validating activities are described below.

\subsubsection{During Identification Phase}

In accordance with the SM Team Charter, the Program Manager conducted a review of the draft Strategy Input Package ${ }^{5}$ for the purpose of validating that the correct functions, requirements, and key assumptions were defined. Concurrence was obtained.

\subsubsection{During Evaluation Phase}

The Program Manager conducted a second review of the $\operatorname{SIP}^{5}$ to revalidate the inputs, to determine if changes occurred or were necessary. The $\mathrm{SIP}^{5}$ was revised to update the space requirements needed each year during the FY-00 to FY-09 time period. The basis for this change to the $\mathrm{SIP}^{5}$ is provided in Reference 4 . The change increased the ten year space requirement from 5,700,000 gallons to 6,043,000 gallons. Concurrence was obtained from the Program Manager. 


\subsection{Idea Identification}

This section is to present the method and results of the SM Team "idea solicitation" process. This activity is considered part of the Identification Phase.

\subsection{Idea Identification Process}

The process utilized by the SM Team to identify candidate ideas for evaluation used a dual avenue approach of 1) brainstorming, and, 2) individual contributor inputs.

To facilitate the solicitation process the SM Team distributed a "Briefing Package" of information. This package contained the following information:

- Problem definition

- Critical mission need

- Top level function and requirements

- The administrative model

- A pro-forma sheet with instructions for submitting an idea

The Briefing Package served as both an education/information tool to provide global constraints that ideas must conform and as a vehicle to submit ideas. The ideas submittal form was referred to as a Pro-Forma Sheet by the SM Team.

"At-Large" distribution of the Briefing Package was made via the Site and Division Chief Engineers Council to organizations in each respective Division.

The SM Team identified subject matter experts and stakeholders to participate in the brainstorming sessions. The SM Team also provided Briefing Packages to the identified participants of the two formal and independent brainstorming sessions held on March 23, 1999. Due to the large number of individuals identified, two separate and formally facilitated sessions were conducted. Each session had a cross-section of participants. Ideas identified were recorded on Pro-Formas for SM Team evaluation.

The SM Team accepted submittals, via Pro-Formas, up until the final selection process was initiated. 


\section{Idea Identification Results}

The output ${ }^{7}$ from the process described in 6.1 was approximately 300 ideas (Pro-Formas) being submitted to the SM Team.

The SM Team was receptive to partial solutions which, when appropriately combined, would yield an entire tank space management Strategy for further evaluation. Subsequent sections of this report discuss how this was done and which Strategies evolved.

\subsection{Idea Categories}

The SM Team reviewed each Pro-Forma in order to understand the idea and request further clarification from the originator, if necessary. Upon completion of this review, ideas were categorized into eight (8) topics based on area of impact or potential implementation. The areas are Administrative, Canyons, Defense Waste Prọcessing Facility (DWPF), Off Site Storage, On site Storage, Alternate Salt Dispositioning, Tank Farms, and Waste Pre-Treatment (WPT). The definition and designated symbol of each category are as follows:

\section{- Administrative ("A"):}

An idea capable of being implemented by a revision to a procedure, authorization basis documentation waste acceptance criteria, planning documents and planning tools or environmental permits. No physical plant modifications are required.

- Canyons ("C"C):

An idea that requires a physical, chemical, operating limit, or equipment change in the $\mathrm{F}$ and/or $\mathrm{H}$ Canyon processes or facilities to allow reduction of Canyon liquid waste.

- Defense Waste Processing Facility (DWPF) (“D”):

An idea that requires a physical, chemical or equipment change in the DWPF process or facility. Also includes ideas that require change to the DWPF Waste Compliance Plan (WCP). 
- Off Site Storage ('F"):

An idea to use off site facilities for processing and storage of waste.

- On Site Storage (“N"):

An idea to use facilities other than HLW facilities for processing and storage of waste.

- Alternative Salt (Alt Salt) (“S”):

An idea associated with the processing salt solution. Utilizing one of the selected alternatives or the proposed pilot plant.

- Tank Farms ("T"):

An idea that requires a physical, chemical or equipment change in the $\mathrm{F}$ and/or $\mathrm{H}$ Tank Farm processes or facilities. Also includes ideas that require change to the Tank Farm $\mathrm{AB}$ and Waste Acceptance criteria.

- Waste Pre-Treatment (WPT) ("W"):

An idea related to the recovery of WPT processing tanks and supporting facilities for waste storage; associated with processing salt through some variation of the existing In-Tank Precipitation (ITP); and/or require a physical, chemical or equipment change to the Extended Sludge Process (ESP) facilities.

A listing of ideas submitted and the categories to which they were assigned exists in Reference 7.

\subsection{Idea Screening}

The SM Team screened each of the ideas to determine if there were any which could not meet certain "Go/No Go" criteria. The Strategy Input Package 5 and Charter ${ }^{2}$ were reviewed to establish these criteria. The criteria selected are listed below. The parenthetical information indicates the source of the criterion.

- Decreases incoming material to the tank farms, increases outgoing material to the tank farms, compresses material within the tank farms, increases available storage space for HLW, or any combination of these four possibilities (SIP: Administrative Model).

- Demonstrated (proven) Technology (SIP Requirement: R-0-9). 
- Assures long-term blend Strategies for the Small Tank Tetraphenylborate (TPB), Crystalline Silicotitanate (CST) Non-Elutable Ion Exchange, and Direct Disposal in Grout alternatives are not compromised (SIP Requirement: R-0-8).

- Risks to the public, worker, and/or environment are maintained within acceptable limits (SIP: Key Assumption).

- $\quad$ NRC licensing not required (SIP: Key Assumption).

- Does not require the use of tanks 17 and 20 (SIP: Key Assumption).

An idea failing to pass any one of the criterion was considered unacceptable, documented as to reason for failure, and eliminated from further consideration. If insufficient information existed to evaluate the idea against the screening criteria, the ideas were carried forward as acceptable.

\subsection{Initial List of Ideas}

The final step of the idea Identification Phase was the generation of the "Initial List" 8 of ideas. To establish this list, the ideas within each category, which passed the "Go/No Go" screening criteria ${ }^{6}$ were reviewed for similarity, redundancy, and/or duplicity. Where similarities exist, the ideas selected for the "Initial List" 8 were chosen based on the most representative and/or inclusiveness of the idea with respect to other ideas in the same category. This step was intended to define obvious combinations. No attempt to "force" the inclusion of one idea into another was made.

The "Initial List" contains seventy-two (72) ideas that were carried forward for more in-depth evaluation by the SM Team. A detailed listing of the "Initial List" is contained in Reference 8.

It is to be noted that each "Initial List" idea is considered technically implementable. No significant scientific issues or uncertainties were identified. Some potential engineering studies to address scaling and sizing may be required to further define an idea, but no technical "show stoppers" exist.

\subsection{Ideas not on "Initial List"}

There are two reasons why an idea does not appear on the "Initial List". First, the idea failed the Go/No Go screening criteria, or secondly, the idea is represented by one or more of the ideas that did make the "Initial List". Reference 8 provides details of the SM Team disposition of ideas at this stage. 


\subsection{Evaluation of Ideas}

The purpose of this section is to describe the Evaluation Phase, which began with the "Initial List"8 of seventy-two (72) ideas (from Section 6.0), subsequently narrowed to the "Intermediate List" of twenty-four (24) ideas, and culminated in a risk analysis of the "Intermediate List" of ideas.

\subsection{Space Gain Ranking}

The Evaluation Phase commenced with the development of calculations to determine the Ten-Year Increase in Available Space (TIAS) gain for each of the "Initial List" ideas. The TIAS values, as measured in K-gallons, were determined by implementation of the desktop procedure ${ }^{6}$ entitled, "Dispositioning the "Initial List" Ideas Based on Available Space Contributions".

The method used to determine the Ten-Year Increase in Available Space is depicted in Figure 7-1. The definitions relevant to this process are described in the glossary (Section 10). The calculations were documented ${ }^{9}$ along with the necessary assumptions and appropriate comments to provide clarification. 
High Level Waste Tank Space

Management Team

Final Report
WSRC-RP-99-00005

Revision: 0

Page 63 of 135

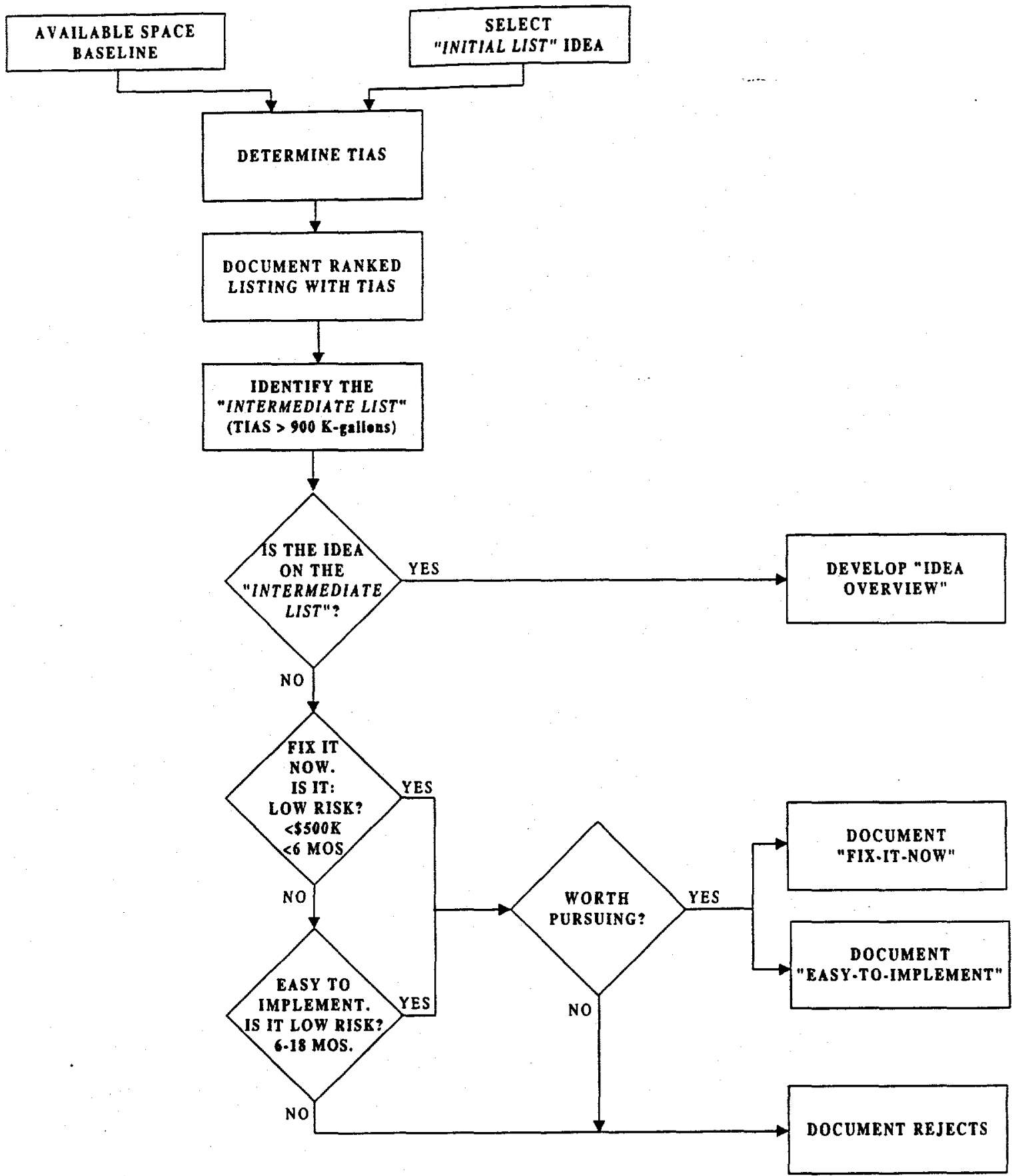

Figure 7-1: TIAS Ranking Process for Initial List Ideas

Table 7-1 provides a numerical ranking of the seventy-two (72) "Initial List" ideas based on TIAS values (largest to smallest). 
Table 7-1: Ranking Initial List Based on TIAS

(Listed in order of decreasing TIAS)

\begin{tabular}{|c|c|c|c|c|c|c|c|}
\hline \multirow[b]{2}{*}{$\begin{array}{l}\text { INITIAL } \\
\text { LIST } \\
\text { IDEA } \\
\text { NO. }\end{array}$} & \multirow[b]{2}{*}{ INITIAL LIST IDEA SUMMARY } & \multicolumn{4}{|c|}{$\begin{array}{l}\text { TIAS SCENARIO } \\
\text { (X those applicable) }\end{array}$} & \multirow[b]{2}{*}{$\begin{array}{r}\text { TIAS } \\
\text { (UNITS }=\mathrm{K} \\
\text { GALLONS) }\end{array}$} & \multirow[b]{2}{*}{$\begin{array}{l}\text { INTERMEDIATE } \\
\text { LIST } \\
\text { IDEA NUMBER }\end{array}$} \\
\hline & & $\begin{array}{l}\text { INCREASES } \\
\text { OUTGOING }\end{array}$ & $\begin{array}{l}\text { NEW } \\
\text { STORAGE } \\
\text { SPACE } \\
\end{array}$ & $\begin{array}{c}\text { COMPRESSES } \\
\text { EXISTING } \\
\text { HLW }\end{array}$ & $\begin{array}{l}\text { REDUCES } \\
\text { INFLUENTS }\end{array}$ & & \\
\hline A-41 & $\begin{array}{l}\text { Do everything listed in Rev. } 10 \text { of the System } \\
\text { Plan. }\end{array}$ & $\mathrm{X}$ & $\mathrm{x}$ & & & 7,566 & IL-2 \\
\hline T-30 & $\begin{array}{l}\text { Allow use of Tanks } 4 \text { through } 8 \text { for salt solution } \\
\text { storage after sludge is removed. }\end{array}$ & & $\mathrm{x}$ & & & 3,750 & IL-3 \\
\hline S-11 & $\begin{array}{l}\text { Dissolve salt cake with low Ci concentration of } \\
\text { Cs-137, e.g., Tank } 38 \text { salt. Do MST strike to } \\
\text { remove } \mathrm{Sr} \text { and alpha. Send to Saltstone. Will } \\
\text { probably require changing Saltstone WAC, } \\
\text { perhaps to Class } \mathrm{B} \text {. }\end{array}$ & $\mathrm{X}$ & & & & 3,430 & IL-6 \\
\hline W-37 & $\begin{array}{l}\text { By increasing the shielding in Z-Area, Saltstone } \\
\text { with higher concentrations of Cs- } 137 \text { can be } \\
\text { disposed up to the Class A limit. If permits are } \\
\text { modified to allow. Class C disposal, MST to } \\
\text { remove alpha would be minimized. }\end{array}$ & $\mathrm{x}$ & • & & & 3,430 & IL-7 \\
\hline A-40 & Shutdown DWPF. & & & & $\mathbf{x}$ & 3,393 & IL-5 \\
\hline$T-56$ & Build new waste tanks to meet space needs. & & $\mathrm{X}$ & & & 3,200 & IL-1 \\
\hline A-32 & $\begin{array}{l}\text { Use Type I Tanks } 4 \text { - } 8 \text { as emergency spare space } \\
\text { so that all Type III tanks can be used for storing } \\
\text { waste. }\end{array}$ & & $\mathrm{X}$ & & & 2,000 & IL-4 \\
\hline
\end{tabular}




\begin{tabular}{|c|c|c|c|c|c|c|c|}
\hline \multirow[b]{2}{*}{$\begin{array}{l}\text { INITIAL } \\
\text { LIST } \\
\text { IDEA } \\
\text { NO. } \\
\end{array}$} & \multirow[b]{2}{*}{ INITIAL LIST IDEA SUMMARY } & \multicolumn{4}{|c|}{$\begin{array}{r}\text { TIAS SCENARIO } \\
\text { (X those applicable) } \\
\end{array}$} & \multirow[b]{2}{*}{$\begin{array}{c}\text { TIAS } \\
\text { (UNITS }=\mathrm{K} \\
\text { GALLONS) }\end{array}$} & \multirow[b]{2}{*}{$\begin{array}{l}\text { INTERMEDIATE } \\
\text { LIST } \\
\text { IDEA NUMBER }\end{array}$} \\
\hline & & $\begin{array}{l}\text { INCREASES } \\
\text { OUTGOING }\end{array}$ & $\begin{array}{l}\text { NEW } \\
\text { STORAGE } \\
\text { SPACE } \\
\end{array}$ & $\begin{array}{c}\text { COMPRESSES } \\
\text { EXISTING } \\
\text { HLW } \\
\end{array}$ & $\begin{array}{l}\text { REDUCES } \\
\text { INFLUENTS }\end{array}$ & & \\
\hline $\mathrm{N}-11$ & $\begin{array}{l}\text { Use reactor drain tanks or other tanks in the } \\
\text { reactors to store low level waste. Possible on-site } \\
\text { storage. }\end{array}$ & & $\mathrm{x}$ & & & 2,000 & IL-8 \\
\hline $\mathrm{T}-3$ & $\begin{array}{l}\text { Evaporate backlog waste. Transfer salt solution in } \\
\text { these tanks to existing evaporator system or the } \\
\text { RHLWE system to evaporate and regain space. } \\
\text { Address tritium limits. }\end{array}$ & $\mathrm{X}$ & & & & 1,526 & IL-10 \\
\hline D-6 & Send DWPF recycle directly to Saltstone. & & & & $\mathrm{X}$ & 1,372 & IL-13 \\
\hline T-57 & $\begin{array}{l}\text { Provide separate emergency storage space for } \\
\text { existing HLW inventory. Buy new tanks to } \\
\text { provide this emergency storage. }\end{array}$ & & $\mathrm{x}$ & & & 1,323 & IL-16 \\
\hline A-38 & $\begin{array}{l}\text { Use space in both areas to meet single TSR } \\
\text { emergency space requirements. Also consider } \\
\text { crediting pump tank volumes. }\end{array}$ & & $\mathrm{X}$ & & & 1,300 & IL-17 \\
\hline$S-14$ & $\begin{array}{l}\text { Send ETF bottoms directly to Saltstone and use } \\
\text { Tank } 50 \text { for waste storage. }\end{array}$ & & $\mathrm{X}$ & & & 1,200 & IL-18 \\
\hline F-10 & $\begin{array}{l}\text { Chem Nuclear in Barnwell has a pilot scale facility } \\
\text { that evaporates aqueous waste to dryness and } \\
\text { places the waste in an NRC-Approved container } \\
\text { qualified for near-surface LLW disposal. Dry salt } \\
\text { from this operation could be stored or disposed in } \\
\text { either E-Area or Z-Area. }\end{array}$ & $\mathrm{X}$ & & & & 1,200 & IL-20 \\
\hline
\end{tabular}




\begin{tabular}{|c|c|c|c|c|c|c|c|}
\hline \multirow[b]{2}{*}{$\begin{array}{l}\text { INITIAL } \\
\text { LIST } \\
\text { IDEA } \\
\text { NO. } \\
\end{array}$} & \multirow[b]{2}{*}{ INITIAL LIST IDEA SUMMARY } & \multicolumn{4}{|c|}{$\begin{array}{l}\text { TIAS SCENARIO } \\
\text { (X those applicable) }\end{array}$} & \multirow[b]{2}{*}{$\begin{array}{c}\text { TIAS } \\
\text { (UNITS }=\mathrm{K} \\
\text { GALLONS) }\end{array}$} & \multirow[b]{2}{*}{$\begin{array}{l}\text { INTERMEDIATE } \\
\text { LIST } \\
\text { IDEA NUMBER }\end{array}$} \\
\hline & & $\begin{array}{l}\text { INCREASES } \\
\text { OUTGOING }\end{array}$ & $\begin{array}{l}\text { NEW } \\
\text { STORAGE } \\
\text { SPACE } \\
\end{array}$ & $\begin{array}{c}\text { COMPRESSES } \\
\text { EXISTING } \\
\text { HLW } \\
\end{array}$ & $\begin{array}{c}\text { REDUCES } \\
\text { INFLUENTS }\end{array}$ & & \\
\hline W-11 & $\begin{array}{l}\text { Recover Tank } 50 \text { for Tank Farm storage. For } \\
\text { example, use the organic waste storage tank or } \\
\text { build a hold tank with the capacity to store about } \\
\text { one month of ETF evaporator concentrate. } \\
\text { Alternatively, use Tank IV tanks to store the } \\
\text { bottoms or grout ETF bottoms in 55-gallon drums. }\end{array}$ & & $\mathrm{X}$ & & & 1,200 & IL-21 \\
\hline N-19 & $\begin{array}{l}\text { Use Tanks from Reactors Areas for ETF Bottoms } \\
\text { (HLW to Tank 50) }\end{array}$ & & $\mathbf{x}$ & & & 1,200 & IL-69 \\
\hline $\mathrm{T}-48$ & Reduce DWPF production to 125 cans/year. & & $\mathrm{X}$ & & & 1200 & IL-72 \\
\hline D-12 & $\begin{array}{l}\text { Split DWPF water into separate streams (chemical } \\
\text { Cell and Melter Off Gas). Evaluate each stream for } \\
\text { Saltstone and ETF; treat, if necessary to meet } \\
\text { WACS. }\end{array}$ & & - & & & 1,176 & IL-11 \\
\hline D-5 & $\begin{array}{l}\text { Treat DWPF Recycle using CST (or other } \\
\text { technology) and send to Saltstone. }\end{array}$ & & & & $\mathbf{X}$ & 1,176 & Il-12 \\
\hline D-13 & $\begin{array}{l}\text { Install evaporator for DWPF Recycle, route } \\
\text { bottoms to DWPF, Overheads to ETF. }\end{array}$ & & & & $\mathrm{x}$ & 1,176 & IL-14 \\
\hline D-37 & $\begin{array}{l}\text { Divert recycle to a separate treatment process } \\
\text { somewhere else based on CST IX and then send } \\
\text { decontaminated waste to Z-Area for disposal as } \\
\text { saltstone. }\end{array}$ & & & & $\mathbf{X}$ & 1,176 & IL-15 \\
\hline D-27 & Reduce DWPF production to 125 cans/year. & & & & $\mathrm{X}$ & 1,175 & IL-24 \\
\hline
\end{tabular}




\begin{tabular}{|c|c|c|c|c|c|c|c|}
\hline \multirow[b]{2}{*}{$\begin{array}{l}\text { INITIAL } \\
\text { LIST } \\
\text { IDEA } \\
\text { NO. }\end{array}$} & \multirow[b]{2}{*}{ INITIAL LIST IDEA SUMMARY } & \multicolumn{4}{|c|}{$\begin{array}{l}\text { TIAS SCENARIO } \\
\text { (X those applicable) }\end{array}$} & \multirow[b]{2}{*}{$\begin{array}{c}\text { TIAS } \\
\text { (UNITS }=\mathrm{K} \\
\text { GALLONS) }\end{array}$} & \multirow[b]{2}{*}{$\begin{array}{l}\text { INTERMEDIATE } \\
\text { LIST } \\
\text { IDEA NUMBER }\end{array}$} \\
\hline & & $\begin{array}{l}\text { INCREASES } \\
\text { OUTGOING }\end{array}$ & $\begin{array}{l}\text { NEW } \\
\text { STORAGE } \\
\text { SPACE } \\
\end{array}$ & $\begin{array}{l}\text { COMPRESSES } \\
\text { EXISTING } \\
\text { HLW } \\
\end{array}$ & $\begin{array}{l}\text { REDUCES } \\
\text { INFLUENTS }\end{array}$ & & \\
\hline W-4 & $\begin{array}{l}\text { Decompose all TPB materials in Tank } 49 \text { (perhaps } \\
\text { simply by waiting a year or so), then transfer to } \\
\text { Tank } 50 \text { to combine with ETF bottoms, or transfer } \\
\text { to Tank } 48 \text {. Return Tank } 49 \text { to HLW storage use. }\end{array}$ & & $\mathrm{X}$ & & & 1,060 & IL-22 \\
\hline A-34 & $\begin{array}{l}\text { Make Tank } 48 \text { and } 49 \text { emergency spare tanks for } \\
\text { Tank Farm, eliminating the need to reserve space } \\
\text { in other HLW tanks. }\end{array}$ & & $\mathrm{X}$ & & & 960 & IL-9 \\
\hline D-3 & $\begin{array}{l}\text { Send more supernate to DWPF by revising glass } \\
\text { quality specifications to allow higher sodium } \\
\text { levels in sludge so less washing is needed. }\end{array}$ & $\mathrm{X}$ & & & & 640 & N/A \\
\hline A-2 & $\begin{array}{l}\text { Increase specific gravity of concentrate from } 1.45 \\
\text { to } 1.60 \text { during evaporator operation. }\end{array}$ & $\mathrm{X}$ & & & & 640 & N/A \\
\hline F-1 & $\begin{array}{l}\text { One or two tanks at AGNS are designed for HLW } \\
\text { storage. Use them in place by transporting waste to } \\
\text { them or move the waste tanks to SRS for use. }\end{array}$ & & $\mathrm{x}$ & & & 600 & N/A \\
\hline W-29 & $\begin{array}{l}\text { Use waste with high hydroxide concentration for } \\
\text { aluminum dissolution rather than fresh sodium } \\
\text { hydroxide. }\end{array}$ & & & & $\mathrm{X}$ & 585 & N/A \\
\hline A-37 & Use ESP tanks for emergency spares. & & $\mathrm{X}$ & & & 568 & N/A \\
\hline A-18 & $\begin{array}{l}\text { Revise the Tank Farm WAC to eliminate practices } \\
\text { that affect space negatively, especially excess } \\
\text { caustic additions and dilution required in canyon. }\end{array}$ & & & & $\mathrm{X}$ & 480 & N/A \\
\hline
\end{tabular}




\begin{tabular}{|c|c|c|c|c|c|c|c|}
\hline \multirow[b]{2}{*}{$\begin{array}{l}\text { INITIAL } \\
\text { IIST } \\
\text { NOA } \\
\end{array}$} & \multirow[b]{2}{*}{ INITIAL LIST IDEA SUMMARY } & \multicolumn{4}{|c|}{$\begin{array}{l}\text { TIAS SCENARIO } \\
\text { (X those applicable) }\end{array}$} & \multirow[b]{2}{*}{$\begin{array}{l}\text { TIAS } \\
\text { (UNITS }=\mathrm{K} \\
\text { GALLONS) }\end{array}$} & \multirow[b]{2}{*}{$\begin{array}{l}\text { INTERMEDIATE } \\
\text { LIST } \\
\text { IDEA NUMBER }\end{array}$} \\
\hline & & $\begin{array}{l}\text { INCREASES } \\
\text { OUTGOING }\end{array}$ & $\begin{array}{l}\text { NEW } \\
\text { STORAGE } \\
\text { SPACE } \\
\end{array}$ & $\begin{array}{c}\text { COMPRESSES } \\
\text { EXISTING } \\
\text { HLW }\end{array}$ & $\begin{array}{l}\text { REDUCES } \\
\text { INFLUENTS }\end{array}$ & & \\
\hline $\mathrm{T}-1$ & $\begin{array}{l}\text { Develop a small evaporator ( } 1-5) \mathrm{gpm} \text { that can be } \\
\text { mounted in a riser. Install on tanks that have } \\
\text { partially concentrate supernate. Concentrate } \\
\text { supernate to } 15-20 \mathrm{M} \mathrm{Na} \text {. Alternative, use natural } \\
\text { evaporation or find other processing equipment. }\end{array}$ & $\mathrm{X}$ & & & & 450 & N/A \\
\hline $\mathrm{T}-87$ & $\begin{array}{l}\text { Reclaim Tanks } 43 \text { \& } 26 \text { for concentrate storage by } \\
\text { shutting down } 2 F \& 2 H \text { Evaporators. }\end{array}$ & & $\mathrm{X}$ & & & 400 & N/A \\
\hline A-27 & $\begin{array}{l}\text { Reschedule sludge processing to process only } F \\
\text { Tank Farm sludge, which does not require } \\
\text { aluminum dissolution. }\end{array}$ & & & & $\mathrm{x}$ & 325 & N/A \\
\hline D-26 & $\begin{array}{l}\text { Update earlier DWPF water study (WSRC-TR-93- } \\
\text { 0677, Dec. } 20,1993 \text { ). Develop and fund a program } \\
\text { to implement. }\end{array}$ & & & & $\mathrm{x}$ & 315 & N/A \\
\hline D-40 & $\begin{array}{l}\text { Process waste in tanks } 48 \text { and } 49 \text { through the } \\
\text { DWPF salt cell. Provides a way to remove organic } \\
\text { waste from these tanks to they can be used for } \\
\text { storage of concentrated supernate and/or salt cake. }\end{array}$ & $\mathrm{X}$ & & & & 300 & N/A \\
\hline W-40 & $\begin{array}{l}\text { Change waste removal priorities so that sludge } \\
\text { from Type III and IIIA tanks is sent to DWPF first. } \\
\text { Leave sludge in Type I, II, and IV tanks until salt } \\
\text { disposition process is operating. }\end{array}$ & $\mathrm{X}$ & & & & 300 & N/A \\
\hline$S-2$ & $\begin{array}{l}\text { Build and operate the alternative salt pilot plant to } \\
\text { reclaim small amounts of space until Alt Salt Plant } \\
\text { is built. }\end{array}$ & $\mathrm{x}$ & & & & 280 & N/A \\
\hline
\end{tabular}




\begin{tabular}{|c|c|c|c|c|c|c|c|}
\hline \multirow[b]{2}{*}{$\begin{array}{l}\text { INITIAL } \\
\text { LIST } \\
\text { IDEA } \\
\text { NO. }\end{array}$} & \multirow[b]{2}{*}{ INITIAL LIST IDEA SUMMARY } & \multicolumn{4}{|c|}{$\begin{array}{l}\text { TIAS SCENARIO } \\
\text { (X those applicable) }\end{array}$} & \multirow[b]{2}{*}{$\begin{array}{l}\text { TIAS } \\
\text { (UNITS }=\mathrm{K} \\
\text { GALLONS) }\end{array}$} & \multirow[b]{2}{*}{$\begin{array}{l}\text { INTERMEDIATE } \\
\text { LIST } \\
\text { IDEA NUMBER }\end{array}$} \\
\hline & & $\begin{array}{l}\text { INCREASES } \\
\text { OUTGOING }\end{array}$ & $\begin{array}{l}\text { NEW } \\
\text { STORAGE } \\
\text { SPACE } \\
\end{array}$ & $\begin{array}{l}\text { COMPRESSES } \\
\text { EXISTING } \\
\text { HLW } \\
\end{array}$ & $\begin{array}{l}\text { REDUCES } \\
\text { INFLUENTS }\end{array}$ & & \\
\hline$T-13$ & $\begin{array}{l}\text { Add telescoping transfer jets to selected tanks. } \\
\text { Telescoping transfer jets allow feed to be drawn } \\
\text { from layers in tanks to promote maximum space } \\
\text { regain, evaporator efficiency and minimize salt } \\
\text { drop out as salt cake. }\end{array}$ & $\mathrm{X}$ & & & & 279 & N/A \\
\hline$T-37$ & $\begin{array}{l}\text { Use the Type IV tanks to store wastes with low } \\
\text { activity, such as the DWPF recycle. }\end{array}$ & & $x$ & & & 260 & N/A \\
\hline$C-14$ & $\begin{array}{l}\text { Place SS tanks in unused portions of canyons. } \\
\text { Store acid byproduct solutions until salt processing } \\
\text { begins. Alternatively, shut down canyon processes } \\
\text { or treat acid waste to enable diversion to other } \\
\text { facilities. }\end{array}$ & & $\mathrm{X}$ & & $\mathrm{x}$ & 250 & N/A \\
\hline A-8 & $\begin{array}{l}\text { Increase operating limit in Type III/IIIA tanks to } \\
\text { tank penetration. For most tanks, this is an increase } \\
\text { of } 3 \text { " in operating limit. }\end{array}$ & & $\mathrm{X}$ & & & 242 & N/A \\
\hline$T-46$ & $\begin{array}{l}\text { Tanks } 18 \text { and } 19 \text { are not closed and could be used } \\
\text { for LLW storage. }\end{array}$ & & $\mathrm{X}$ & & & 180 & N/A \\
\hline D-19 & $\begin{array}{l}\text { During melter idling, flow to both SASs in the } \\
\text { DWPF Melter Off Gas system should be stopped } \\
\text { after the cold cap has disappeared }(\sim 6 \mathrm{hr} .) \text {. }\end{array}$ & & . & & $\mathrm{X}$ & 146 & $\mathrm{~N} / \mathrm{A}$ \\
\hline W-41 & $\begin{array}{l}\text { Send just enough salt to DWPF to make up for } \\
\text { lack of precipitate perhaps by washing sludge less. } \\
\text { Do not increase canister production or change } \\
\text { glass quality specifications. }\end{array}$ & $\mathrm{X}$ & & & & 97 & N/A \\
\hline
\end{tabular}




\begin{tabular}{|c|c|c|c|c|c|c|c|}
\hline \multirow[b]{2}{*}{$\begin{array}{l}\text { INITIAL } \\
\text { LIST } \\
\text { IDEA } \\
\text { NO. } \\
\end{array}$} & \multirow[b]{2}{*}{ INITIAL LIST IDEA SUMMARY } & \multicolumn{4}{|c|}{$\begin{array}{l}\text { TIAS SCENARIO } \\
\text { (X those applicable) }\end{array}$} & \multirow[b]{2}{*}{$\begin{array}{l}\text { TIAS } \\
\text { (UNITS }=\mathrm{K} \\
\text { GALLONS) }\end{array}$} & \multirow[b]{2}{*}{$\begin{array}{l}\text { INTERMEDIATE } \\
\text { LIST } \\
\text { IDEA NUMBER }\end{array}$} \\
\hline & & $\begin{array}{l}\text { INCREASES } \\
\text { OUTGOING }\end{array}$ & $\begin{array}{l}\text { NEW } \\
\text { STORAGE } \\
\text { SPACE } \\
\end{array}$ & $\begin{array}{l}\text { COMPRESSES } \\
\text { EXISTING } \\
\text { HLW }\end{array}$ & $\begin{array}{l}\text { REDUCES } \\
\text { INFLUENTS }\end{array}$ & & \\
\hline D-46 & $\begin{array}{l}\text { Melter salt waste into sludge stream being } \\
\text { processed in DWPF. }\end{array}$ & $\mathrm{X}$ & & & & 97 & N/A \\
\hline D-43 & $\begin{array}{l}\text { Change the amount of frit and water used to } \\
\text { decontaminate canisters. Use the amount needed } \\
\text { for the actual Ci content of the feed rather than the } \\
\text { design values. }\end{array}$ & & & & $\mathrm{X}$ & 50 & N/A \\
\hline D-28 & $\begin{array}{l}\text { Current RCT transfer operations requires three } \\
\text { batch transfers to the Recycle Waste Tank (RWT) } \\
\text { in the LPPP. By bypassing the RWT in the LPPP } \\
\text { and transferring directly to the Tank Farm, two } \\
\text { RCT pump primes in the DWPF are eliminated } \\
(\sim 120 \text { gal/RCT batch). }\end{array}$ & & & & $X$ & 44 & N/A \\
\hline D-30 & $\begin{array}{l}\text { SMECT scrubber pump has plugged J-Tube which } \\
\text { prevents priming the pump at low tank levels, so } \\
\text { several thousand gallons of water must be added to } \\
\text { restart pump ( } 4 \text { to } 6 \text { times a year). }\end{array}$ & & & & $\mathrm{X}$ & 38 & N/A \\
\hline W-33 & $\begin{array}{l}\text { Optimize sludge washing to reduce the amount of } \\
\text { wash water. Develop detailed fragnets and } \\
\text { assumptions for Al dissolution and washing. }\end{array}$ & & & & $\mathrm{x}$ & 21 & N/A \\
\hline D-39 & $\begin{array}{l}\text { Use DWPF recycle for rewetting dry sludge rather } \\
\text { than inhibited water. The recycle waste is already } \\
\text { inhibited and avoids adding salt in a "new" } \\
\text { inhibited water. }\end{array}$ & & & & $\mathrm{X}$ & 14 & N/A \\
\hline
\end{tabular}




\begin{tabular}{|c|c|c|c|c|c|c|c|}
\hline \multirow[b]{2}{*}{$\begin{array}{l}\text { INITIAL } \\
\text { LIST } \\
\text { IDEA } \\
\text { NO. } \\
\end{array}$} & \multirow[b]{2}{*}{ INITIAL LIST IDEA SUMMARY } & \multicolumn{4}{|c|}{$\begin{array}{l}\text { TIAS SCENARIO } \\
(\mathrm{X} \text { those applicable })\end{array}$} & \multirow[b]{2}{*}{$\begin{array}{c}\text { TIAS } \\
\text { (UNITS = K } \\
\text { GALLONS) }\end{array}$} & \multirow[b]{2}{*}{$\begin{array}{c}\text { INTERMEDIATE } \\
\text { LIST } \\
\text { IDEA NUMBER }\end{array}$} \\
\hline & & $\begin{array}{l}\text { INCREASES } \\
\text { OUTGOING } \\
\end{array}$ & $\begin{array}{c}\text { NEW } \\
\text { STORAGE } \\
\text { SPACE } \\
\end{array}$ & $\begin{array}{c}\text { COMPRESSES } \\
\text { EXISTING } \\
\text { HLW }\end{array}$ & $\begin{array}{l}\text { REDUCES } \\
\text { INFLUENTS }\end{array}$ & & \\
\hline T-58 & $\begin{array}{l}\text { Provide emergency storage space by placing tanks } \\
\text { within the old evaporator cell. }\end{array}$ & & $X$ & & & 7 & N/A \\
\hline D-29 & $\begin{array}{l}\text { Provide a jumper to route DWPF recycle waste to } \\
\text { Tank } 51 \text { or Tank } 40 \text { flush connections to use the } \\
\text { dilute DWPF recycled waste for flushing instead } \\
\text { of clean inhibited water. Alternatively, flush with } \\
\text { well water (no inhibitors). }\end{array}$ & & & & $\mathrm{X}$ & 3 & N/A \\
\hline$T-24$ & $\begin{array}{l}\text { Flush water can be minimized by making it an } \\
\text { optimization criteria for planning a transfer. }\end{array}$ & & & & $\mathrm{X}$ & 1 & N/A \\
\hline D-32 & $\begin{array}{l}\text { Present DWPF treatment for HEPAs is based on } \\
\text { caustic dissolution of fiberglass filters that is then } \\
\text { combined with other recycle waste. By converting } \\
\text { to acid decontamination and disposal as solid } \\
\text { waste, salt generated from HEPA } \\
\text { treatment/disposal is never generated. }\end{array}$ & & & & $X$ & 1 & N/A \\
\hline C. 20 & $\begin{array}{l}\text { Reduce NMSS waste as much as possible without } \\
\text { curtailing missions, e.g., reduce PVV flushes, } \\
\text { increase acid stripping, use HAN, eliminate or } \\
\text { decrease poisons, use electrolytic dissolver to } \\
\text { destroy nitrate. }\end{array}$ & & & & $\mathrm{x}$ & 1 & N/A \\
\hline A-14 & $\begin{array}{l}\text { Improve WCS database to } 1 \text { ) ensure information is } \\
\text { update, 2) better waste characterization. Would } \\
\text { improve our ability to confidently forecast. }\end{array}$ & & & & & $<1$ & N/A \\
\hline
\end{tabular}




\begin{tabular}{|c|c|c|c|c|c|c|c|}
\hline ing & > & & $\begin{array}{r}\text { TIAS } \\
\text { (X thos } \\
\end{array}$ & $\begin{array}{l}\text { ENARIO } \\
\text { pplicable) }\end{array}$ & & & \\
\hline $\begin{array}{l}\text { INITIAL } \\
\text { LIST } \\
\text { IDEA } \\
\text { NO. } \\
\end{array}$ & INITIAL LIST IDEA SUMMARY & $\begin{array}{l}\text { INCREASES } \\
\text { OUTGOING }\end{array}$ & $\begin{array}{l}\text { NEW } \\
\text { STORAGE } \\
\text { SPACE }\end{array}$ & $\begin{array}{c}\text { COMPRESSES } \\
\text { EXISTING } \\
\text { HLW } \\
\end{array}$ & $\begin{array}{l}\text { REDUCES } \\
\text { INFLUENTS }\end{array}$ & $\begin{array}{l}\text { TIAS } \\
\text { (UNITS }=K \\
\text { GALLONS) }\end{array}$ & $\begin{array}{l}\text { INTERMEDIATE } \\
\text { LIST } \\
\text { IDEA NUMBER }\end{array}$ \\
\hline A-13 & $\begin{array}{l}\text { Confirm space gain factors to improve our ability } \\
\text { to confidently plan future Tank Farm space. }\end{array}$ & & & & & $<1$ & N/A \\
\hline T-9 & $\begin{array}{l}\text { Determine best way to operate evaporators to } \\
\text { maximize space gain, e.g., make liquor where } \\
\text { appropriate rather than salt cake, continuous vs. } \\
\text { batch processing, recycle timing. }\end{array}$ & & & & & $<1$ & N/A \\
\hline A-12 & $\begin{array}{l}\text { Develop better performance indicators for material } \\
\text { movement so that decision makers are attuned to } \\
\text { when something will impact Tank Farm space. }\end{array}$ & & & & & $<1$ & N/A \\
\hline T-65 & $\begin{array}{l}\text { Remove cesium from waste by adding zeolite to } \\
\text { Tank } 42 \text {, send cleaned supernate to Saltstone. }\end{array}$ & $\mathrm{X}$ & & & & 0 & $\mathrm{~N} / \mathrm{A}$ \\
\hline A-11 & $\begin{array}{l}\text { Revisit Harry Harmon task team initiative. } \\
\text { Boundary conditions were well defined and } \\
\text { evaluated to better understand process viabilities } \\
\text { (Contact Jerry Morin). }\end{array}$ & & & & & 0 & N/A \\
\hline $\mathrm{T}-36$ & $\begin{array}{l}\text { Eliminate FFA restrictions on use of Type I, II, IV } \\
\text { by modifying the tanks (liners, under liner leak } \\
\text { detection). }\end{array}$ & & & & & 0 & N/A \\
\hline A-23 & $\begin{array}{l}\text { Improve system plan and model to remove fat } \\
\text { (conservatism) by using root-mean-sum-of-squares } \\
\text { methodology to obtain more realistic projections }\end{array}$ & & & & & 0 & N/A \\
\hline A-16 & $\begin{array}{l}\text { Establish financial incentives to minimize } \\
\text { influents, or establish volume limits for accepted } \\
\text { waste. }\end{array}$ & & & & & 0 & N/A \\
\hline
\end{tabular}




\begin{tabular}{|c|c|c|c|c|c|c|c|}
\hline \multirow{2}{*}{$\begin{array}{c}\text { INITIAL } \\
\text { LIST } \\
\text { IDEA } \\
\text { NO. } \\
\end{array}$} & \multirow[b]{2}{*}{ INITIAL LIST IDEA SUMMARY } & \multicolumn{4}{|c|}{$\begin{array}{l}\text { TIAS SCENARIO } \\
\text { (X those applicable) }\end{array}$} & \multirow[b]{2}{*}{$\begin{array}{c}\text { TIAS } \\
\text { (UNITS }=\mathrm{K} \\
\text { GALLONS) }\end{array}$} & \multirow[b]{2}{*}{$\begin{array}{l}\text { INTERMEDIATE } \\
\text { LIST } \\
\text { IDEA NUMBER }\end{array}$} \\
\hline & & $\begin{array}{l}\text { INCREASES } \\
\text { OUTGOING }\end{array}$ & $\begin{array}{l}\text { NEW } \\
\text { STORAGE } \\
\text { SPACE } \\
\end{array}$ & $\begin{array}{c}\text { COMPRESSES } \\
\text { EXISTING } \\
\text { HLW }\end{array}$ & $\begin{array}{l}\text { REDUCES } \\
\text { INFLUENTS }\end{array}$ & & \\
\hline$A \cdot 1$ & $\begin{array}{l}\text { Leave salt in old style tanks until disposition } \\
\text { process needs feed (leave salt in tanks } 1,2,3,9 \text { ). } \\
\text { Requires modifications to the FFA and FFCA Site } \\
\text { Treatment Plan. }\end{array}$ & & & & & 0 & N/A \\
\hline S-5 & $\begin{array}{l}\text { Send salt solution that will meet Saltstone disposal } \\
\text { requirements without further treatment to Z-Area } \\
\text { for disposal as saltstone. Blend ETF bottoms, if } \\
\text { necessary. }\end{array}$ & & & & & 0 & N/A \\
\hline $\mathrm{T}-12$ & $\begin{array}{l}\text { Leaking coils can consume valuable space. Early } \\
\text { detection would minimize the affect on available } \\
\text { space. Also consider improving tank level } \\
\text { indicators. }\end{array}$ & & & & $\mathrm{X}$ & 0 & N/A \\
\hline $\mathrm{T}-23$ & $\begin{array}{l}\text { Limit slurry pump operation to reduce seal } \\
\text { leakage. }\end{array}$ & & & & $\mathrm{X}$ & 0 & N/A \\
\hline A-19 & $\begin{array}{l}\text { Establish performance indicators on chemical } \\
\text { waste generators overtime to improve basis for } \\
\text { forecasts and identifying places to reduce Salt } \\
\text { Waste. }\end{array}$ & & & & & 0 & N/A \\
\hline W-45 & Build ESP Facility (HLW to Tank $40 \& 51$ ) & & $\mathbf{X}$ & & & 0 & N/A \\
\hline A-25 & $\begin{array}{l}\text { Privatize the problem, allowing private capital } \\
\text { (borrowed, if needed) to be used without } \\
\text { exceeding federal budget limits. }\end{array}$ & & & & & 0 & N/A \\
\hline A-29 & Delay tank closure to keep space available & & & & & 0 & N/A \\
\hline
\end{tabular}




\subsection{Intermediate List. Ideas}

The SM Team defined an Intermediate List $^{9}$ idea as one having $\geq 900 \mathrm{~K}$-gal. of TIAS. The bases for this cut-off level are as follows:

a) $900 \mathrm{~K}$ gal. is a close approximation to a Type I, II, III, IV HLW Tank.

b) This is the TIAS value below which the smaller space gain ideas referred to as "Fix-It-Now" and "Easy-To-Implement" ideas begin to appear and will be evaluated in parallel to the major space gaining ideas.

c) The requirement (Reference 5) to obtain the lost Tank 40 one million gallon space as soon as possible.

d) The slope of the space demand curve in Reference 5 averages about $800 \mathrm{~K}$ gallons per year.

A comparison of the Intermediate List $^{9}$ to the Initial List $^{8}$, based on TIAS values, is shown in Figure 7-2.

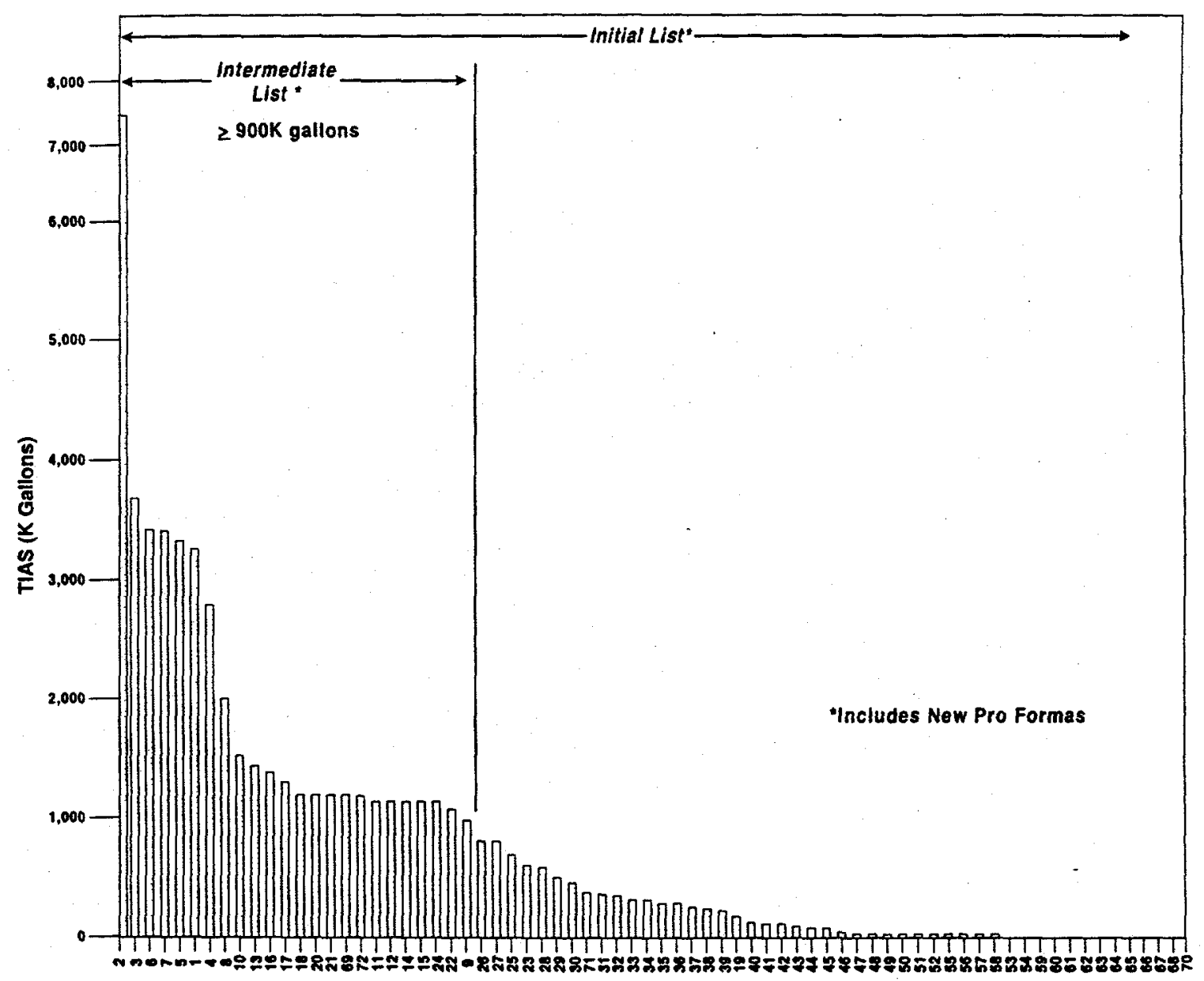

Figure 7-2: Intermediate List versus Initial List Ranking Profile 
A cross reference between the Intermediate List idea number and the original Initial List idea number is shown in Table 7-2.

During this phase, Intermediate List idea IL-2, "HLW System Plan, Rev. 10" was identified as a stand-alone Strategy consisting of several other Intermediate List ideas, i.e., $\mathbb{L}-10,22,4$, and 18. For the purpose of this report, $\mathbb{I L}-2$ is evaluated as a Strategy and not as an idea. 
Table 7-2: Summary of Intermediate List Ideas Based on TIAS Values (High to Low)

\begin{tabular}{|c|c|c|c|}
\hline $\begin{array}{l}\text { Intermediate } \\
\text { List Number }\end{array}$ & $\begin{array}{c}\text { Initial List } \\
\text { Number }\end{array}$ & $\begin{array}{l}\text { Intermediate List Idea Title } \\
\end{array}$ & $\begin{array}{l}\text { TIAS } \\
\text { (K Gal) }\end{array}$ \\
\hline IIL-2 & $\mathrm{A}-41$ & HLW System Plan, Rev. 10 & 7,566 \\
\hline$\overline{L L}-3$ & T-30 & Use Tanks 4 through 8 for HLW Concentrate Storage. & 3,750 \\
\hline IL-6 & S-11 & Process Salt Cake with Low Cs-137 into Class B Saltstone. & 3,430 \\
\hline IL-7 & $\mathrm{W}-37$ & Process Salt Cake with Low Cs-137 into Class C Saltstone. & 3,430 \\
\hline $\mathrm{IL}-5$ & A-40 & DWPF Shutdown, FY-01 to FY-09. & 3,393 \\
\hline IL-1 & T-56 & Build new HLW Waste Tanks. & 3,200 \\
\hline IL-4 & $\mathrm{A}-32$ & Tanks $4-8$ for Emergency Space. & 2,600 \\
\hline IL-8 * & $\mathrm{N}-11$ & Tanks in Reactor Areas for HLW. & 2,000 \\
\hline IL-10 & T-3 & Evaporate backlog waste. & 1,526 \\
\hline $\mathrm{IL}-13 *$ & D-6 & Send DWPF recycle to Z-Area. & 1,372 \\
\hline IL-16 & T-57 & Small Tanks for Emergency Space. & 1,323 \\
\hline IL-17 & A-38 & Reduce Emergency Space to $1300 \mathrm{~K}$ gallons. & 1,300 \\
\hline IL-18 & S-14 & ETF Bottoms Direct to Saltstone. & 1,200 \\
\hline $\mathrm{IL}-20 *$ & F-10 & Send ETF Bottoms to ChemNuclear (HLW to Tank 50). & 1,200 \\
\hline IL-21 & $\mathrm{W}-11$ & New Tank for ETF Bottoms (HLW to Tank 50). & 1,200 \\
\hline IL-69 & $\mathrm{N}-19$ & Use Tanks from Reactor Areas for ETF Bottoms (HLW to Tank 50). & 1,200 \\
\hline IIL-72 & T-48 & Store ETF Bottoms in Type IV Tanks (HLW to Tank 50) & 1,200 \\
\hline IL-11 & $\mathrm{D}-12$ & Evaporator in the Salt Cell for DWPF Recycle. & 1,176 \\
\hline IL-12 & D-5 & Treat DWPF recycle using CST and send to Saltstone. & 1,176 \\
\hline$\overline{\mathrm{L}}-14$ & $\mathrm{D}-13$ & Evaporator in LWF for DWPF Recycle. & 1,176 \\
\hline$\overline{\mathrm{LL}}-15$ & D-37 & Treat DWPF Recycle in a Waste Tank and Portable Unit to Meet WAC for Z-Area. & 1,176 \\
\hline$\overline{\mathrm{IL}}-24$ & D-27 & Reduce DWPF Production to 125 Canisters Per Year & 1,175 \\
\hline IL-22 & W-4 & Allow TPB in Tank 49 to Decompose (HLW to Tank 49) & 1,060 \\
\hline $\mathrm{IL}-9 *$ & $\mathrm{~A}-34$ & Tank 48 and 49 as Emergency Space. & 960 \\
\hline
\end{tabular}

*Subsequently dropped from further consideration due to risk (see Section 7.5). 


\subsection{Intermediate List Overviews}

Each of the twenty-four (24) ideas making up the "Intermediate List" has unique features, assumptions, and unit operations associated with it. The SM Team developed more detailed summaries of each "Intermediate List" ideas for the purpose of clarifying the idea and to prevent multiple interpretations. The method used to document these overviews is referred to as an Idea Overview Summary and are provided in Reference 9. The overviews were used to further evaluate the ideas during the Evaluation Phase. As part of the idea overviews, the profile of the Ten-Year Increase in Available Space over the period of FY2000 through FY2009 was also determined.

\subsection{Ideas Not On Intermediate List}

Forty-eight (48) "Initial List" ideas did not meet the criterion of producing $>900 \mathrm{~K}$ gallons of TIAS. However, the SM Team did not want to ignore the possibility that, of these forty-eight ideas, there may be relatively simple and cost effective solutions, albeit in smaller space gains, which may be usable in developing long term Strategies for HLW space management. As such, these forty-eight ideas were considered as potential small space gain contributors if they fell into one of two classifications referred to as 1) "Fix-it-now", and 2) "Easy-to-implement". The criteria for each is:

- "Fix-it-now" Ideas: An idea, with $<900 \mathrm{~K}$ gallons of TIAS, which is considered low risk because it is estimated to cost $<\$ 500 \mathrm{~K}$ and requires $<$ six months to implement.

- "Easy-to-implement" Ideas: An idea, with < 900K gallons of TIAS, which is considered low risk because it requires six (6) to eighteen months to implement.

Upon SM Team review, it was determined that none of the ideas fit the "Fix-itnow" classification. Table 7-3 lists the "Small Volume Gains" associated with the "Easy-to-implement" ideas. Details of the SM Team's disposition on these ideas are contained in Reference 9. 
Table 7-3: "Small Volume Gains" Ideas

\begin{tabular}{|c|c|c|c|c|c|}
\hline $\begin{array}{c}\text { INITIAL } \\
\text { LIST } \\
\text { IDEA } \\
\text { NO. } \\
\end{array}$ & INITIAL LIST IDEA TITLE & $\begin{array}{l}\text { ESTIMATED } \\
\text { TIME TO } \\
\text { IMPLEMENT }\end{array}$ & $\begin{array}{l}\text { ESTIMATED } \\
\text { COST TO } \\
\text { IMPLEMENT }\end{array}$ & $\begin{array}{c}\text { TIAS } \\
\text { (UNITS = } \\
\text { K GALLONS) }\end{array}$ & COMMENTS \\
\hline W-29 & $\begin{array}{l}\text { Perform Al Dissolution with High } \\
\text { Hydroxide Waste } \\
\text { Use waste with high hydroxide } \\
\text { concentration for aluminum dissolution } \\
\text { rather than fresh sodium hydroxide. }\end{array}$ & $12 \mathrm{Mo}$. & $\begin{array}{c}\text { 300K } \\
\text { 100K FY01 } \\
200 \mathrm{~K} \text { FY02 }\end{array}$ & $\begin{array}{c}585 \\
135 \text { FY03 } \\
194 \text { FY06 } \\
256 \text { FY09 }\end{array}$ & $\begin{array}{l}\text { Sludge Batch } 3 \text { Al Diss - FY02 } \\
\text { Sludge Batch } 4 \text { Al Diss - FY05 } \\
\text { Sludge Batch } 3 \text { Al Diss - FY08 }\end{array}$ \\
\hline A-18 & $\begin{array}{l}\text { Revisit Tank Farm WAC } \\
\text { Revise the Tank Farm WAC to eliminate } \\
\text { practices that affect space negatively, } \\
\text { especially excess caustic additions and } \\
\text { dilution required in canyon. }\end{array}$ & $18 \mathrm{Mo}$. & $\begin{array}{c}500 \mathrm{~K} \\
100 \mathrm{~K} \text { FY00 } \\
200 \mathrm{~K} \text { FY01 } \\
200 \mathrm{~K} \text { FY02 }\end{array}$ & $\begin{array}{c}480 \\
\text { Evenly spread } \\
\text { over } 10 \text { years }\end{array}$ & $\begin{array}{l}\text { Engineering resources needed. } \\
\text { Requires WAC revisions. } \\
\text { Increased operational } \\
\text { complexity } \\
\text { TIAS may be impacted if other } \\
\text { major ideas implemented } \\
\end{array}$ \\
\hline $\mathrm{T}-13$ & $\begin{array}{l}\text { Add Telescoping Transfer Jets to Selected } \\
\text { Tanks } \\
\text { Some current jets don't allow full } \\
\text { evaporation of existing waste. Also, } \\
\text { Telescoping transfer jets in drop tanks may } \\
\text { allow feed to be drawn from layers in tanks } \\
\text { to promote maximum space regain, } \\
\text { evaporator efficiency and minimize salt } \\
\text { drop out as salt cake. }\end{array}$ & $12 \mathrm{Mo} . \mathrm{Ea}$. & $\begin{array}{l}1,000 \mathrm{~K} \\
\text { 250K FY00 } \\
\text { (Tk35) } \\
250 \mathrm{~K} \mathrm{FY01} \\
\text { (Tk39) } \\
250 \mathrm{~K} \mathrm{FY02} \\
\text { (Tk30) } \\
250 \mathrm{~K} \mathrm{FY03} \\
\text { (Tk38) }\end{array}$ & $\begin{array}{c}500 \\
300 \text { FY01 } \\
200 \text { FY02 } \\
\text { Future gains } \\
\text { TBD }\end{array}$ & $\begin{array}{l}\text { Project to purchase new jets and } \\
\text { dispose of existing jets required. } \\
\text { Emphasis on Tanks } 35 \text { and } 39 \text { for } \\
\text { largest TIAS gain. }\end{array}$ \\
\hline
\end{tabular}




\begin{tabular}{|c|c|c|c|c|c|}
\hline $\begin{array}{l}\text { INITIAL } \\
\text { LIST } \\
\text { IDEA } \\
\text { NO. }\end{array}$ & INITIAL LIST IDEA TITLE & $\begin{array}{l}\text { ESTIMATED } \\
\text { TIME TO } \\
\text { IMPLEMENT }\end{array}$ & $\begin{array}{l}\text { ESTIMATED } \\
\text { COST TO } \\
\text { IMPLEMENT }\end{array}$ & $\begin{array}{c}\text { TIAS } \\
\text { (UNITS = } \\
\text { K GALLONS) }\end{array}$ & COMMENTS \\
\hline $\mathrm{T}-37$ & $\begin{array}{l}\text { Use the Type IV Tanks to Store Wastes } \\
\text { with Low Activity } \\
\text { Use Type IV Tanks (Tanks } 23 \& 24 \text { ) for } \\
\text { long term storage of low activity waste } \\
\text { (e.g. DWPF recycle and ESP Washwater) } \\
\text { up to } 2.6 \text { Million gallons, if space not } \\
\text { available in Type III tanks }\end{array}$ & 6 Mo. Per Tank & $\begin{array}{c}500 \mathrm{~K} \\
250 \mathrm{~K} \text { FY00 } \\
250 \mathrm{~K} \text { FY01 }\end{array}$ & $\begin{array}{l}\quad 260 \\
\text { Implemented on } \\
\text { as needed basis. }\end{array}$ & $\begin{array}{l}\text { Requires credible transfer path to } \\
\text { Tanks } 23 \text { and } 24 \text {. Could be above } \\
\text { ground. Install early to provide } \\
\text { maximum flexibility. }\end{array}$ \\
\hline T-87 & $\begin{array}{l}\text { Reclaim Tank } 26 \text { by placing } 2 \mathrm{~F} \text { evaporator } \\
\text { in Warm Standby. } \\
\text { Place } 2 \mathrm{~F} \text { evaporator in Warm Standby and } \\
\text { use reserved Tank } 26 / 40 \text { working space for } \\
\text { concentrated supernate storage. }\end{array}$ & $12 \mathrm{Mo}$. & $500 \mathrm{~K}$ & $\begin{array}{l}200 \\
\text { See comment } \\
\text { section for } \\
\text { implementation } \\
\text { timing. }\end{array}$ & $\begin{array}{l}\text { - Several factors must be } \\
\text { assessed before } \\
\text { implementation: } \\
\text { - Operating condition of } 2 \\
\text { hand of RHLWE. } \\
\text { - Need for salt space versus } \\
\text { Tank } 46 \text { salt level. } \\
\text { - } \quad \text { F canyon processing plans. } \\
\text { - Potential for higher TIAS value } \\
\text { - Dependent on concentration } \\
\text { - } \text { of waste in Tank } 46 \text { and } 26 . \\
\text { Eliminate Tank } 26 \text { feed } \\
\text { pump operating limit } \\
\text { restriction. }\end{array}$ \\
\hline
\end{tabular}




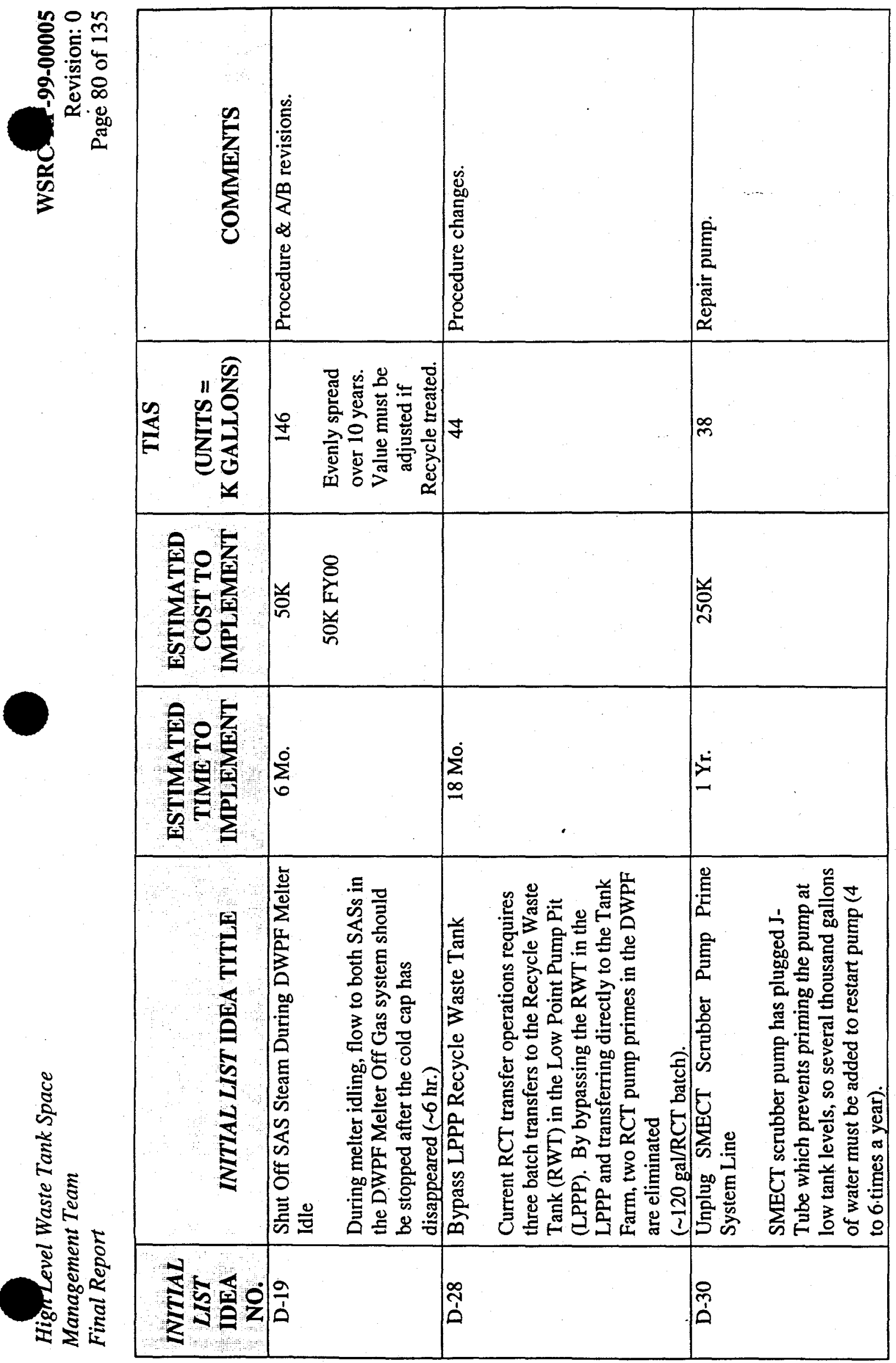




\begin{tabular}{|c|c|c|c|c|c|}
\hline $\begin{array}{l}\text { INITIAL } \\
\text { LIST } \\
\text { IDEA } \\
\text { NO. } \\
\end{array}$ & INITIAL LIST IDEA TITLE & $\begin{array}{l}\text { ESTIMATED } \\
\text { TIME TO } \\
\text { IMPLEMENT }\end{array}$ & $\begin{array}{l}\text { ESTIMATED } \\
\text { COST TO } \\
\text { IMPLEMENT }\end{array}$ & $\begin{array}{c}\text { TIAS } \\
\text { (UNITS }= \\
\text { K GALLONS) }\end{array}$ & COMMENTS \\
\hline W-33 & $\begin{array}{l}\text { Optimize Washwater Use at ESP } \\
\text { Optimize sludge washing to reduce the } \\
\text { amount of wash water. Develop detailed } \\
\text { fragnets and assumptions for aluminum } \\
\text { dissolution and washing. }\end{array}$ & $6 \mathrm{Mo}$ & & 21 & $\begin{array}{l}\text { Use DWPF recycle water for } \\
\text { washwater where possible. }\end{array}$ \\
\hline $\mathrm{C}-20$ & $\begin{array}{l}\text { Reduce NMSS Waste Receipts } \\
\text { Reduce NMSS waste as much as possible } \\
\text { without curtailing missions, e.g., reduce } \\
\text { PVV flushes, increase acid stripping, use } \\
\text { HAN, eliminate or decrease poisons, use } \\
\text { electrolytic dissolver to destroy nitrate. }\end{array}$ & $18 \mathrm{Mo}$. & & 1 & $\begin{array}{l}\text { This item would work with A-14, } \\
\text { A-13, and A-18, to aid in material } \\
\text { tracking and better performance. }\end{array}$ \\
\hline T-24 & $\begin{array}{l}\text { Optimize Use of Flush Water After } \\
\text { Transfers } \\
\text { Flush water can be minimized by making it } \\
\text { an optimization criteria for planning a } \\
\text { transfer. }\end{array}$ & 1 Yr. & & 1 & Revise procedures. \\
\hline A-12 & $\begin{array}{l}\text { Develop Better Performance Indicators } \\
\text { Develop better performance indicators for } \\
\text { material movement so that decision makers } \\
\text { are attuned to when something will impact } \\
\text { Tank Farm space. }\end{array}$ & 1 Yr. & & $<1$ & Improved performance. \\
\hline
\end{tabular}




\begin{tabular}{|c|c|c|c|c|c|}
\hline $\begin{array}{l}\text { INITIAL } \\
\text { LIST } \\
\text { IDEA } \\
\text { NO. }\end{array}$ & INITIAL LIST IDEA TITLE & $\begin{array}{l}\text { ESTIMATED } \\
\text { TIME TO } \\
\text { IMPLEMENT }\end{array}$ & $\begin{array}{l}\text { ESTIMATED } \\
\text { COST TO } \\
\text { IMPLEMENT }\end{array}$ & $\begin{array}{c}\text { TIAS } \\
\text { (UNITS }= \\
\text { K GALLONS) }\end{array}$ & COMMENTS \\
\hline$A-13$ & $\begin{array}{l}\text { Confirm Space Gain Factors } \\
\text { Confirm space gain factors to improve our } \\
\text { ability to confidently plan future Tank } \\
\text { Farm space. }\end{array}$ & $1 \mathrm{Yr}$. & & $<1$ & Improved material tracking. \\
\hline A-14 & $\begin{array}{l}\text { Improve WCS Database } \\
\text { Improve WCS database to 1) ensure } \\
\text { information is update, 2) better waste } \\
\text { characterization. Would improve our } \\
\text { ability to confidently forecast. }\end{array}$ & $1 \mathrm{Yr}$. & & $<1$ & Improved material tracking. \\
\hline T-9 & $\begin{array}{l}\text { Optimize Evaporator Operation } \\
\text { Determine best way to operate evaporators } \\
\text { to maximize space gain, e.g., make liquor } \\
\text { where appropriate rather than salt cake, } \\
\text { continuous vs. batch processing, recycle } \\
\text { timing. }\end{array}$ & $1 \mathrm{Yr}$. & & $<1$ & Improved operations. \\
\hline
\end{tabular}




\subsection{Risk Analysis of Intermediate List Ideas}

This section describes the process and results of the risk analysis performed on the Intermediate List ideas.

Risk Analysis is vital to the success of any program strategy or project. In order to credibly claim an expectation of success in any activity, it is necessary to investigate potential risk, devise Strategies to minimize threats to success, and assess the residual risk. Risk management was also prescribed as a SM Team activity in the Charter. ${ }^{2}$

While the SM Team recognized that risk analysis was a necessary component of chartered activities, it also recognized that the detail to which risk analysis could be applied varied with the depth of knowledge available as the ideas and Strategies evolved. In order to assure objective and uniform assignment of risk, risks were based on the perceived capability of how well the idea or Strategies could meet the defined Strategy Input ${ }^{5}$. The analysis focused on the ability to meet the necessary and sufficient functions and requirements.

The risk analysis was conducted in accordance with desktop procedure ${ }^{6}$ entitled, "Risk Analysis". The analysis was based on the level of detail available. The methodology used to analyze risk is depicted in Figure 7-3. Risk analysis includes the identification of risk, assessing the significance and likelihood of risk, and defining risk handling strategies with associated costs and schedules to implement. The definitions relevant to this process are described in Section 10.0 (Glossary). 


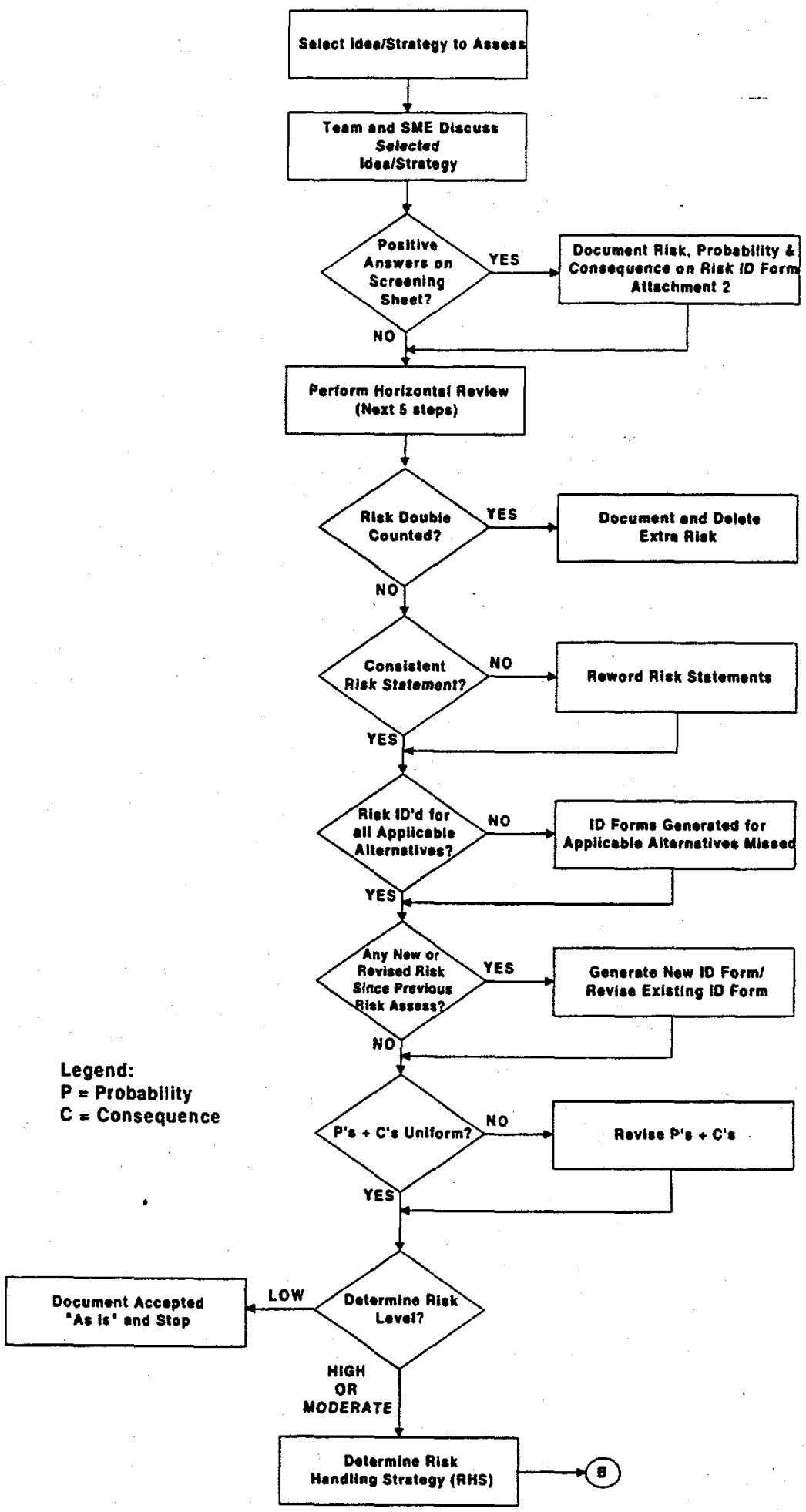

Figure 7-3: Risk Analysis Process 


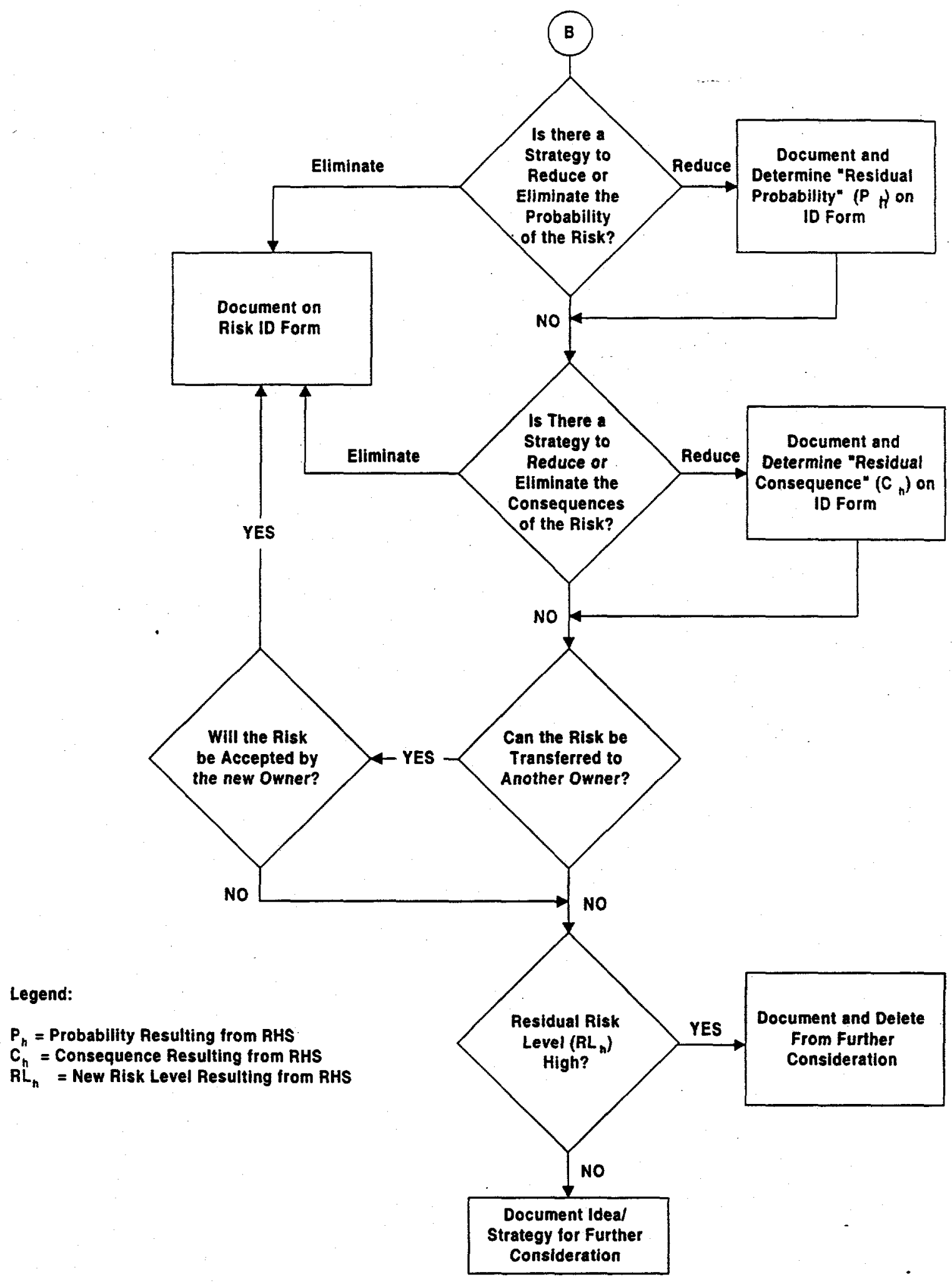

Figure 7-3: Risk Analysis Process (Cont.) 


\subsubsection{Risk Analysis of Intermediate List Ideas}

A risk assessment was performed on the Intermediate List of ideas. Each idea was independently analyzed for risk. The risk assessment started with the development of a risk screening checklist. Available templates were reviewed by the SM Team and modified to reflect risk areas and questions that the SM Team felt were applicable to the mission. The identified risk screening areas were mission, receipt of waste, storage of waste, processing of waste, removal of waste, and "other". Each screening area had between two (2) and six (6) detailed questions to help develop appropriate risks.

The ideas were then individually screened and analyzed for risks. When a potential risk was determined, a "Statement of Risk" was defined. An identification form was created for each risk statement. This form also contains SM Team evaluations of probability and consequences of the risk occurrences. Probability and consequence were stated qualitatively. The bases for the probabilities and consequences are recorded on the forms.

After the checklist areas and forms were completed for an idea, the SM Team performed a horizontal review to assure that probabilities and consequences were uniformly and consistently stated. This review assured that risks were applied to each applicable idea and that consistent levels were used for comparable risks.

Risk handling strategies were then developed for "high" risks. High risks were defined as those with probability and consequence levels as shown in Table 7-4. The risk handling strategy developed was documented on the identification form and, where applicable, the impacts of the handling strategy on risk probability and consequence were estimated and documented. 


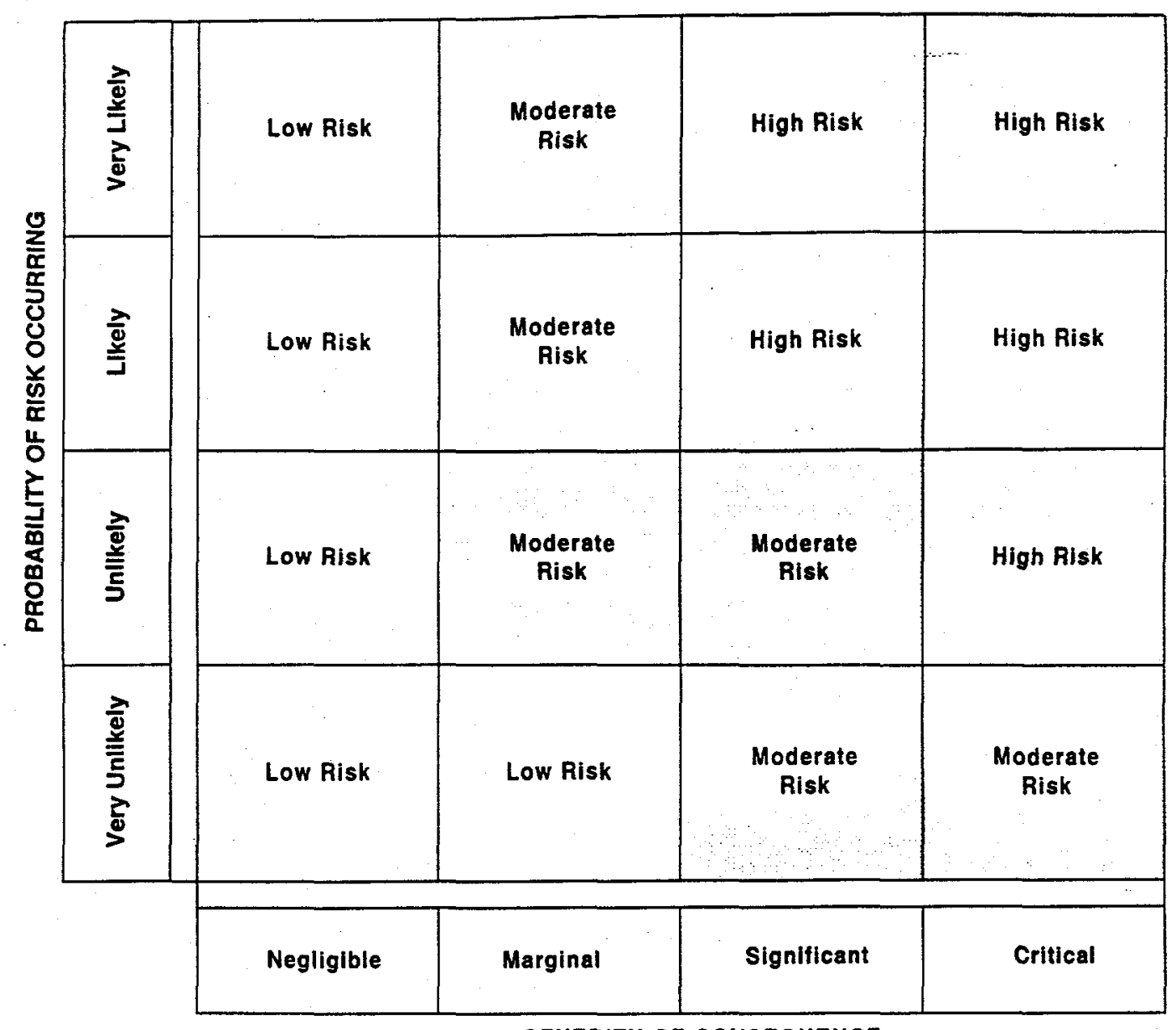

SEVERITY OF CONSEQUENCE

Table 7-4: Risk Level (RL) Determination Matrix

\subsubsection{Results of Risk Analysis}

The assessment and development of risk handling strategies was useful to the SM Team as a means of identifying risks associated with the Intermediate List ideas, understanding the nature of the risks, developing approaches to address the risks, and eliminating those ideas which remained high risk from further consideration. 
The ideas on the "Intermediate List" which were dropped from further consideration based on "unmitigable high risks" are:

- IL-8: "Use Tanks in Reactor Areas for HLW"

The high residual risk ( 8 B.3) remains because the complexity of the operations may be unmanageable. The complexity is deemed comparable to an inter-area transfer between F Tank Farm and H Tank Farm. Furthermore, six separate tank farms must be operated to implement this idea. For these tanks, 200 separate transfers are needed to fill each tank. Tanks are several miles from existing Tank Farms and waste must be transported over roads.

- IL-9: "Make Tanks 48 \& 49 Emergency Spare Tanks"

The high residual risk ( 9 B.5) remains because of the inability to develop an Authorization Basis (AB) for Tank 48 that will address the safety issues associated with adding waste to Tank 48. Reuse of Tank 49 alone is addressed in IL-22.

- IL-13: "Send DWPF Recycle Directly to Saltstone"

The high residual risk (13 A.2) remains because of a concern that DOE will not agree to dispose of TRU waste at SRS. Saltstone made from this waste could exceed Class $C$ grout for alpha activity and be classified as TRU waste.

- IL-20: "Send ETF Bottoms to ChemNuclear (HLW to Tank 50)"

The high residual risk (20 A.2) remains because of the possibility that the ChemNuclear plant may not be able to accept RCRA waste for processing and disposal. Chromate in the waste will cause dried salt to fail TCLP. Waste would be classified as mixed waste.

The "Results Report on the Risk Analysis of Intermediate List Ideas" 12 contains the detailed risk analysis information by the SM Team for each Intermediate List idea. 


\subsection{Strategy Development}

This section defines the process and results obtained in developing Strategies which satisfy the functions and requirements. The functions and requirements are defined in the Strategy Input Package ${ }^{5}$. The model used to develop Strategies is illustrated in Figure 8-1.

The Intermediate List of ideas which were individually assessed for risks (Section 7.0) became the inputs the SM Team used to "develop" various Strategies. Each idea or combination of ideas which satisfies the minimum requirements of the SIP with respect to available space in the timeframe needed, was identified.

The desktop procedure methodology used to develop Strategies is described in Reference 6.

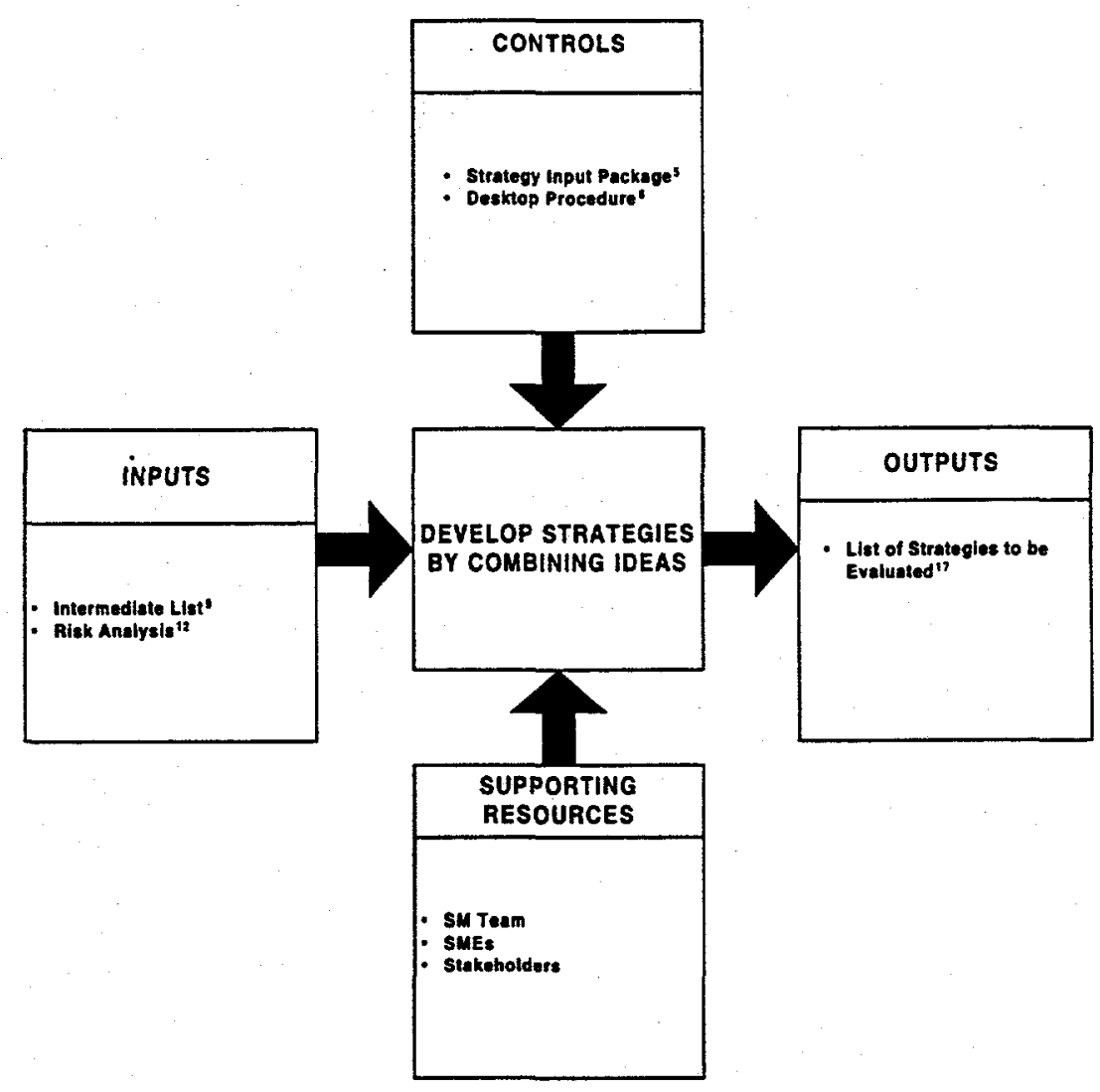

Figure 8-1: Model of Inputs, Controls, Supports and Outputs in Developing a List of Strategies 


\subsection{Available Space Baseline (ASB) Profile}

Intermediate List idea II-2 is the only individual idea which satisfied the $\mathrm{ASB}^{4}$ and was considered a Strategy (S-114) for subsequent evaluation purposes and removed from the Intermediate List. $\mathrm{IL}-2$ actually consists of Intermediate List ideas $10,22,18$, and 3 . Because none of the remaining individual nineteen (19) Intermediate List ideas satisfies the Ten-Year Increase in Available Space (TIAS) needed, ideas must be combined to yield a Strategy that will provide the needed space. To prevent combinations of ideas that will not provide the space needed each year, an $\mathrm{ASB}^{4}$ profile for the space needed was developed as shown in Figure 8-2. The data show a total space need of 5,600 Kgal through FY2009 and $6,040 \mathrm{Kgal}$ through March of 2010, which is six months beyond the period of interest (FY2000 through FY2009). To assure a Strategy would provide the space throughout the desired time range, the $\mathrm{ASB}^{4}$ value for FY2009 was increased from $5,600 \mathrm{Kgal}$ to $6,040 \mathrm{Kgal}$. Avallable

Space

Requirements

(K Gallons)

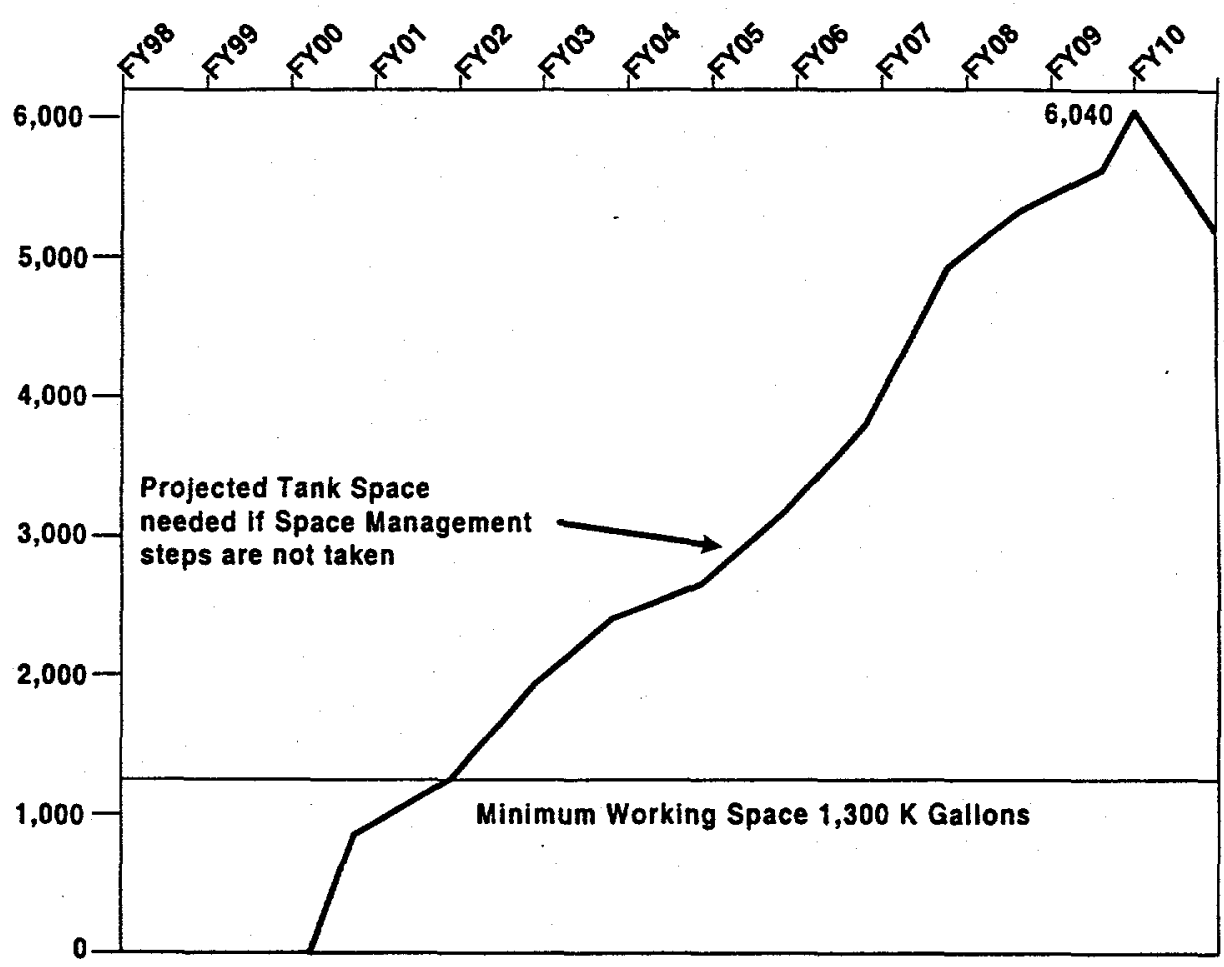

Figure 8-2: Cumulative Increase in Available Space Needed per $\mathrm{ASB}^{4}$ 


\subsection{Elimination of Combinations with Mutually Exclusive Ideas}

Because several of the Intermediate List ideas are functionally equivalent, groupings of mutually exclusive ideas were developed to prevent combinations containing two or more functionally equivalent ideas. For example, a combination of ideas cannot contain both "DWPF Shutdown" and "Reduce DWPF Production to 125 Canisters per Year" since it is physically impossible to implement both of these ideas in a single Strategy. A matrix identifying mutually exclusive ideas is shown in Figure 8-3. 


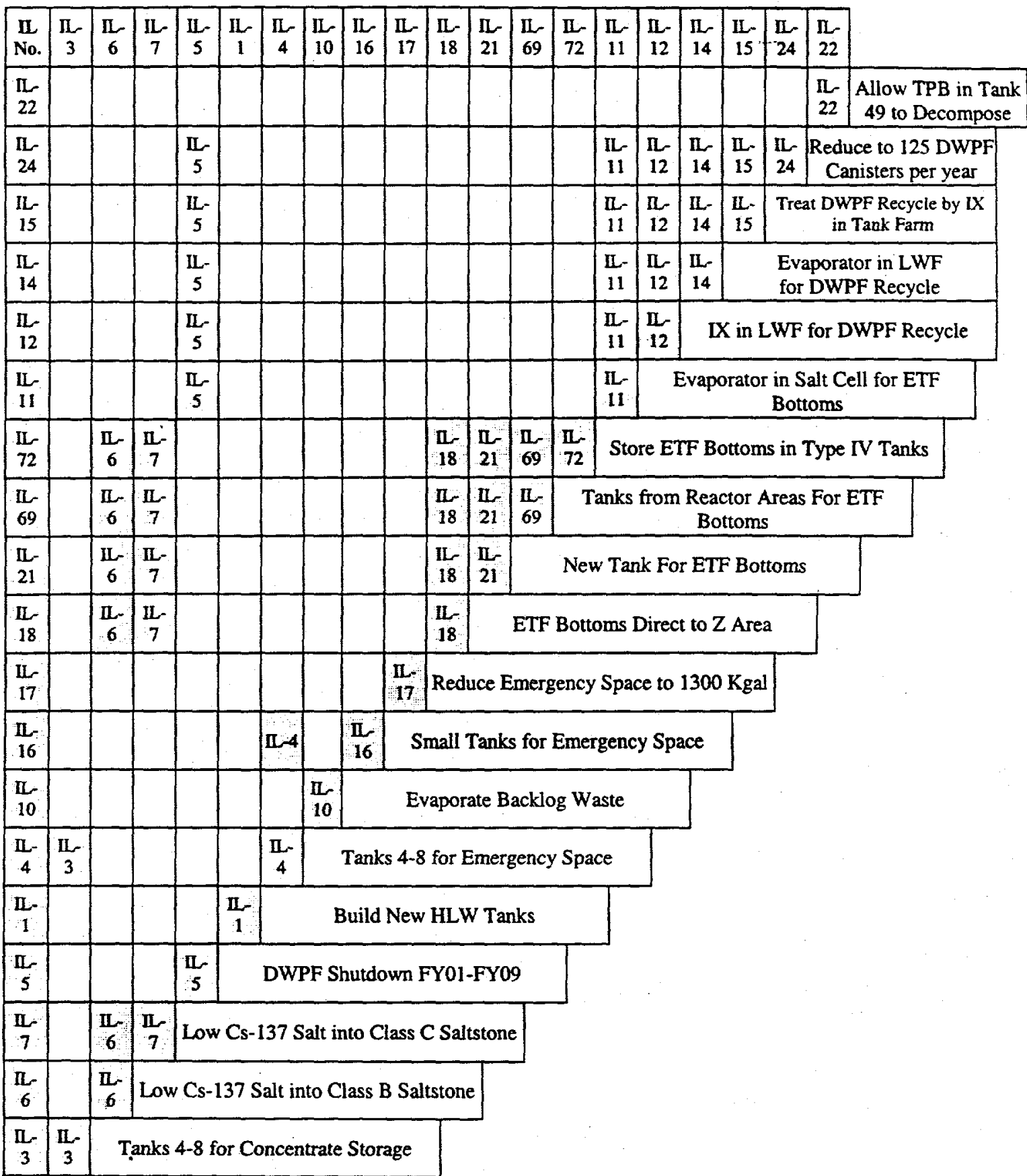

Figure 8-3: Matrix of Mutually Exclusive Ideas

LEGEND: Shaded boxes identify mutually exclusive ideas. 


\subsection{Elimination of Combinations of Ideas Failing to Meet the ASB Profile}

Any combinations of ideas that met or exceeded the volumes defined by the $\mathrm{ASB}^{4}$ curve were retained as possible Strategies and combinations that failed to meet the $\mathrm{ASB}^{4}$ volume needs throughout the period were eliminated. After eliminating combinations that failed to meet the $\mathrm{ASB}^{4}$ curve, a total of 530 possible combinations of ideas remained.

\subsection{Elimination of Duplicate Combinations of Ideas}

As combinations of ideas were developed, a different order for the same combination of ideas was often generated, leading to duplicate combinations. Because these combinations are composed of the same ideas, those duplicates would be eliminated.

\subsection{Elimination of Superfluous Combinations of Ideas}

The list also contains superfluous Strategies, in which an unneeded idea was added to a combination that already met the $\mathrm{ASB}^{4}$ curve for all ten years. Superfluous combinations were eliminated by comparing the remaining list of combination of ideas independently generated ${ }^{14}$. After elimination of superfluous ideas a total of 179 combinations of ideas remained. These were designated as unique Strategies for further evaluation.

\subsection{Identified Strategies}

The list of identified Strategies is provided in Table 8-1. This list represents each combination of Intermediate List ideas which satisfy the minimum requirements of the $\mathrm{ASB}^{4}$ and are non-duplicative and non-superfluous. The "Results Report on the Development of Tank Space Management Strategies"16 details SM Team activities in the developmental documentation of the 179 strategies. 
Table 8-1: HLW Tank Space Management Strategy List

\begin{tabular}{|c|c|c|c|c|c|c|c|c|c|c|c|c|}
\hline \multirow[t]{2}{*}{$\begin{array}{l}\text { Strategy } \\
\text { Tracking } \\
\text { Number }\end{array}$} & \multirow{2}{*}{$\begin{array}{c}\text { Strategy } \\
\text { (Intermediate } \\
\text { List Ideas and } \\
\text { Sequence of } \\
\text { Implementation) }\end{array}$} & \multirow{2}{*}{$\begin{array}{c}\text { Average } \\
\text { Annual } \\
\text { Surplus } \\
\text { relative to } \\
\text { space need } \\
\text { curve (kgal) } \\
\end{array}$} & \multicolumn{10}{|c|}{$\begin{array}{l}\text { Cumulative IAS by Year and Sorted by Ascending } \\
\text { TIAS (K-Gal) in the Year } 2009\end{array}$} \\
\hline & & & $\begin{array}{l}\text { Year } \\
2000\end{array}$ & $\begin{array}{l}\text { Year } \\
2001\end{array}$ & $\mid \begin{array}{l}\text { Year } \\
2002\end{array}$ & $\left|\begin{array}{l}\text { Year } \\
2003\end{array}\right|$ & $\begin{array}{l}\text { Year } \\
2004\end{array}$ & $\begin{array}{l}\text { Year } \\
2005\end{array}$ & $\begin{array}{l}\text { Year } \\
2006\end{array}$ & $\begin{array}{l}\text { Year } \\
2007\end{array}$ & $\begin{array}{l}\text { Year } \\
2008\end{array}$ & $\begin{array}{l}\text { Year } \\
2009\end{array}$ \\
\hline S-1 & $10,5,18$ & 592 & 1044 & 2200 & 2428 & 2820 & 3122 & 4628 & 5065 & 5430 & 5681 & 6119 \\
\hline S-2 & $10,5,21$ & 712 & 1044 & 2200 & 2428 & 2820 & 4322 & 4628 & 5065 & 5430 & 5681 & 6119 \\
\hline $\mathrm{S}-3$ & $10,5,72$ & 832 & 1044 & 2200 & 2428 & 4020 & 4322 & 4628 & 5065 & 5430 & 5681 & 6119 \\
\hline$S-4$ & $10,5,69$ & 712 & 1044 & 2200 & 2428 & 2820 & 4322 & 4628 & 5065 & 5430 & 5681 & 6119 \\
\hline$S-5$ & $10,17,5$ & 1162 & 1044 & 3500 & 3728 & 4120 & \begin{tabular}{|l|}
4422 \\
\end{tabular} & 4728 & 5165 & 5530 & 5781 & 6219 \\
\hline S-6 & $0,5,16$ & & 1044 & 2200 & 2428 & 2820 & 3122 & 3806 & 4715 & 5553 & 5804 & 6242 \\
\hline S-7 & $10,17,6$ & 633 & 759 & 2826 & 2826 & 2826 & 2826 & 4056 & 4926 & 5386 & 6256 & 6256 \\
\hline $\mathrm{S}-8$ & $10,17,7$ & 633 & 759 & 2826 & 2826 & 2826 & 2826 & 4056 & 4926 & 5386 & 6256 & 6256 \\
\hline S-9 & $10,17,22$, & & 868 & 4180 & 4010 & 4257 & 4414 & 5733 & 5781 & 5924 & 6030 & 6261 \\
\hline S-10 & $10,17,22,24,21$ & 1604 & 868 & 4180 & 4010 & 4257 & 5614 & 5733 & 5781 & 5924 & 6030 & 6261 \\
\hline S-11 & $10,17,22,24,72$ & 1724 & 868 & 4180 & 4010 & 5457 & 5614 & 5733 & 5781 & 5924 & 6030 & 6261 \\
\hline $\mathrm{S}-12$ & $10,17,22$, & 1604 & 868 & 4180 & 4010 & 4257 & 5614 & 5733 & 5781 & 5924 & 6030 & 6261 \\
\hline $\mathrm{S}-13$ & $10,17,22,11,18$ & 1323 & 759 & 3886 & 3886 & 3886 & 4082 & 5478 & 5674 & 5870 & 6066 & 6262 \\
\hline S-14 & $0,17,22,1$ & 1323 & 759 & 3886 & 3886 & 3886 & 4082 & 5478 & 5674 & 5870 & 6066 & 6262 \\
\hline $\mathrm{S}-15$ & $10,17,22,1$ & 132 & 759 & 3886 & 3886 & 3886 & 4082 & 5478 & 5674 & 5870 & 6066 & 6262 \\
\hline $\mathrm{S}-16$ & $10,17,22$, & 1323 & 759 & 3886 & 3886 & 3886 & 4082 & 5478 & 5674 & 5870 & 6066 & 6262 \\
\hline S-17 & $10,17,22,11,21$ & 1443 & 759 & 3886 & 3886 & 3886 & 5282 & 5478 & 5674 & 5870 & 6066 & 6262 \\
\hline $\mathrm{S}-18$ & $10,17,22,12,21$ & 1443 & 759 & 3886 & 3886 & 3886 & 5282 & 5478 & 5674 & 5870 & 6066 & 6262 \\
\hline S-19 & $10,17,22,14,21$ & 1443 & 759 & 3886 & 3886 & 3886 & 5282 & 5478 & 5674 & 5870 & 6066 & 6262 \\
\hline $\mathrm{S}-20$ & $10,17,22,15,21$ & 1443 & 759 & 3886 & 3886 & 3886 & 5282 & 5478 & 5674 & 5870 & 6066 & 6262 \\
\hline$S-21$ & $10,17,22,11,72$ & 1563 & 759 & 3886 & 3886 & 5086 & 5282 & 5478 & 5674 & 5870 & 6066 & 6262 \\
\hline$S-22$ & $0,17,22,12,72$ & 1563 & 759 & 3886 & 3886 & 5086 & 5282 & 5478 & 5674 & 5870 & 6066 & 6262 \\
\hline$S-23$ & $10,17,22,14,72$ & 1563 & 759 & 3886 & 3886 & 5086 & 5282 & 5478 & 5674 & 5870 & 6066 & 6262 \\
\hline $\mathrm{S}-24$ & $10,17,22,15,72$ & 1563 & 759 & 3886 & 3886 & 5086 & 5282 & 5478 & 5674 & 5870 & 6066 & 6262 \\
\hline $\mathrm{S}-25$ & $10,17,22,11,69$ & 1443 & 759 & 3886 & 3886 & 3886 & 5282 & 5478 & 5674 & 5870 & 6066 & 6262 \\
\hline$S-26$ & $10,17,22,12,69$ & 1443 & 759 & 3886 & 3886 & 3886 & 5282 & 5478 & 5674 & 5870 & 6066 & 6262 \\
\hline S-27 & $10,17,22,14,69$ & 1443 & 759 & 3886 & 3886 & 3886 & 5282 & 5478 & 5674 & 5870 & 6066 & 6262 \\
\hline S-28 & $10,17,22,15,69$ & 1443 & 759 & 3886 & 3886 & 3886 & 5282 & 5478 & 5674 & 5870 & 6066 & 6262 \\
\hline S-29 & $10,22,24,16,18$ & 834 & 868 & 2880 & 2710 & 2957 & 3114 & 4811 & 5331 & 5947 & 6053 & 6284 \\
\hline$S-30$ & $10,22,21,24,16$ & 954 & 868 & 2880 & 2710 & 2957 & 4314 & 4811 & 5331 & 5947 & 6053 & 6284 \\
\hline S-31 & $10,22,72,24,16$ & 1074 & 868 & 2880 & 2710 & 4157 & 4314 & 4811 & 5331 & 5947 & 6053 & 6284 \\
\hline$S-32$ & $10,22,69,24,16$ & 954 & 868 & 2880 & 2710 & 2957 & 4314 & 4811 & 5331 & 5947 & 6053 & 6284 \\
\hline
\end{tabular}


High Level Waste Tank Space

Management Team

Final Report
WSRC-RP-99-00005

Revision: 0

Page 95 of 135

\begin{tabular}{|c|c|c|c|c|c|c|c|c|c|c|c|c|}
\hline \multirow{2}{*}{$\begin{array}{l}\text { Strategy } \\
\text { Tracking } \\
\text { Number }\end{array}$} & \multirow{2}{*}{$\begin{array}{c}\text { Strategy } \\
\text { (Intermediate } \\
\text { List Ideas and } \\
\text { Sequence of } \\
\text { Implementation) }\end{array}$} & \multirow{2}{*}{$\begin{array}{c}\text { Average } \\
\text { Annual } \\
\text { Surplus } \\
\text { relative to } \\
\text { space need } \\
\text { curve (kgal) }\end{array}$} & \multicolumn{10}{|c|}{$\begin{array}{l}\text { Cumulative IAS by Year and Sorted by Ascending } \\
\text { TIAS (K-Gal) in the Year } 2009\end{array}$} \\
\hline & & & $\begin{array}{l}\text { Year } \\
2000\end{array}$ & $\mid \begin{array}{l}\text { Year } \\
2001\end{array}$ & {$\left[\begin{array}{l}\text { Year } \\
2002\end{array}\right.$} & $\begin{array}{l}\text { Year } \\
2003\end{array}$ & $\begin{array}{l}\text { Year } \\
2004\end{array}$ & $\begin{array}{l}\text { Year } \\
2005\end{array}$ & $\begin{array}{l}\text { Year } \\
2006\end{array}$ & $\begin{array}{l}\text { Year } \\
2007\end{array}$ & $\begin{array}{l}\text { Year } \\
2008\end{array}$ & $\left\{\begin{array}{l}\text { Year } \\
2009\end{array}\right.$ \\
\hline S-33 & & & & & & & & 4556 & & 5893 & & \\
\hline S-34 & 16 & & 759 & & $6 \longdiv { 2 5 8 6 }$ & & 3982 & & 5224 & 5893 & 6089 & \begin{tabular}{|l|l|}
96285 \\
\end{tabular} \\
\hline$S-35$ & 16 & & 759 & & $6 \mid 2586$ & & 3982 & 4556 & 5224 & 5893 & 6089 & $9 \longdiv { 6 2 8 5 }$ \\
\hline$S-36$ & $10,22,2$ & & 759 & 25 & 52586 & 2586 & 3982 & 4556 & 5224 & 5893 & 6089 & 6285 \\
\hline S-37 & $10,22,72,11,16$ & & 759 & $9 \longdiv { 2 5 8 6 }$ & 2586 & 3786 & 3982 & 4556 & 5224 & 5893 & 6089 & 962 \\
\hline$S-38$ & $10,22,72,12,16$ & 913 & 759 & $9 \longdiv { 2 5 8 6 }$ & 52586 & 3786 & 3982 & 4556 & 5224 & 5893 & 6089 & 96285 \\
\hline S-39 & $10,22,7$ & 913 & 759 & $9 \longdiv { 2 5 8 6 }$ & 2586 & 3786 & 3982 & 4556 & 5224 & 5893 & 6089 & 96285 \\
\hline $\mathrm{S}-40$ & $10,22,72$ & 913 & 759 & $9 \longdiv { 2 5 8 6 }$ & 2586 & 3786 & 3982 & 4556 & 5224 & 5893 & 6089 & 96285 \\
\hline $\mathrm{S}-41$ & $10,22,6$ & 793 & 759 & 92586 & 52586 & 2586 & 3982 & 4556 & 5224 & 5893 & 6089 & 96285 \\
\hline$S-42$ & $10,22,6$ & 793 & 759 & 92586 & 52586 & 2586 & 3982 & 4556 & 5224 & 5893 & 6089 & 96285 \\
\hline$S-43$ & 10,22 & 793 & 759 & $9 \longdiv { 2 5 8 6 }$ & 2586 & 2586 & 3982 & 4556 & 5224 & 5893 & 6089 & 96285 \\
\hline$S-44$ & $\sqrt{10,22}$ & 793 & $\overline{759}$ & $9 \longdiv { 2 5 8 6 }$ & 2586 & 2586 & 3982 & 4556 & 5224 & 5893 & 6089 & 96285 \\
\hline$S-45$ & 10,4 & 949 & 868 & $8 \longdiv { 2 8 8 0 }$ & 3460 & 3707 & 3864 & 3983 & 5531 & 5674 & 5780 & 6361 \\
\hline S-46 & 10,4, & 788 & 759 & $9 \longdiv { 2 5 8 6 }$ & 53336 & 3336 & 3532 & 3728 & 5424 & 5620 & 5816 & 6362 \\
\hline$S-47$ & 10,4 & 78 & 759 & $9 \longdiv { 2 5 8 6 }$ & 3336 & 3336 & 3532 & 3728 & 5424 & 5620 & 5816 & 6362 \\
\hline $\mathrm{S}-48$ & 10,4 & 78 & 759 & $9 \longdiv { 2 5 8 6 }$ & 53336 & 3336 & 3532 & 3728 & 5424 & 5620 & 5816 & 6362 \\
\hline S-49 & 10,4 & 78 & 759 & $9 \longdiv { 2 5 8 6 }$ & 3336 & 3336 & 3532 & 3728 & 5424 & 5620 & 5816 & 6362 \\
\hline S-50 & 4,16 & 1404 & 868 & $8 \longdiv { 4 1 8 0 }$ & 4010 & 4257 & 4414 & 4911 & 5431 & 6047 & 6153 & 36384 \\
\hline$S-51$ & & & 759 & $9 \longdiv { 3 8 8 6 }$ & 3886 & 3886 & 4082 & 4656 & 5324 & 5993 & & 96385 \\
\hline$S-52$ & & & 759 & 33886 & 3886 & 3886 & 4082 & 4656 & 5324 & 5993 & 6189 & 96385 \\
\hline$S-53$ & 10,17 , & & 759 & $9 \longdiv { 3 8 8 6 }$ & 3886 & 3886 & 4082 & 4656 & 5324 & 5993 & 6189 & 96385 \\
\hline S-54 & $10,17,22,15,16$ & 1243 & 759 & $9 \longdiv { 3 8 8 6 }$ & 3886 & 3886 & 4082 & 4656 & 5324 & 5993 & 6189 & 96385 \\
\hline$S-55$ & $10,4,22,18$ & 977 & 759 & $9 \longdiv { 2 5 8 6 }$ & 3336 & 3336 & 3336 & 4536 & 6036 & 6036 & 6036 & 66386 \\
\hline$S-56$ & $10,4,22,21$ & 1097 & 759 & 2586 & 53336 & 3336 & 4536 & 4536 & 6036 & 6036 & 6036 & 66386 \\
\hline S-57 & $10,4,22,72$ & 1217 & 759 & $9 \longdiv { 2 5 8 6 }$ & 3336 & 4536 & 4536 & 4536 & 6036 & 6036 & 6036 & 66386 \\
\hline$S-58$ & $10,4,22,69$ & 1097 & 759 & $9 \longdiv { 2 5 8 6 }$ & 3336 & 3336 & 4536 & 4536 & 6036 & 6036 & 6036 & 6386 \\
\hline$S-59$ & $10,17,22,16,18$ & 1431 & $\overline{759}$ & $9 \longdiv { 3 8 8 6 }$ & 3886 & 3886 & 3886 & 5464 & 5936 & 6409 & 6409 & 6409 \\
\hline$S-60$ & $2,16,21$ & 1551 & 759 & $9 \longdiv { 3 8 8 6 }$ & 3886 & 3886 & 5086 & 5464 & 5936 & 6409 & 6409 & 6409 \\
\hline$S-61$ & & 16 & 759 & $9 \longdiv { 3 8 8 6 }$ & 3886 & 5086 & 5086 & 5464 & 5936 & 6409 & 6409 & 6409 \\
\hline$S-62$ & $10,17,22,16,69$ & & 759 & $9 \longdiv { 3 8 8 6 }$ & 3886 & 3886 & 5086 & 5464 & 5936 & 6409 & 6409 & 96409 \\
\hline S-63 & $10,4,22,17$ & 1547 & 759 & $9 \longdiv { 3 8 8 6 }$ & 4636 & 4636 & 4636 & 4636 & 6136 & 6136 & 6136 & 64 \\
\hline S-64 & 1 & & 868 & $8 \longdiv { 1 8 2 0 }$ & 2400 & 2647 & 2804 & 4123 & 5671 & 5814 & 5920 & 6501 \\
\hline$S-65$ & $, 4,24,21$ & 715 & 868 & $8 \mid 1820$ & 2400 & 2647 & 4004 & 4123 & 5671 & 5814 & 5920 & 6501 \\
\hline S-66 & 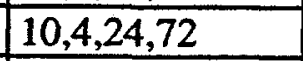 & 835 & 868 & $8 \longdiv { 1 8 2 0 }$ & 2400 & 3847 & 4004 & 4123 & 5671 & 5814 & 5920 & 6501 \\
\hline S-67 & $10,4,24,69$ & 715 & 868 & $8 \longdiv { 1 8 2 0 }$ & 2400 & 2647. & 4004 & 4123 & 5671 & 5814 & 5920 & 6501 \\
\hline
\end{tabular}




\begin{tabular}{|c|c|c|c|c|c|c|c|c|c|c|c|c|}
\hline \multirow[t]{2}{*}{$\begin{array}{l}\text { Strategy } \\
\text { Tracking } \\
\text { Number }\end{array}$} & \multirow{2}{*}{$\begin{array}{c}\text { Strategy } \\
\text { (Intermediate } \\
\text { List Ideas and } \\
\text { Sequence of } \\
\text { Implementation) }\end{array}$} & \multirow{2}{*}{$\begin{array}{c}\text { Average } \\
\text { Annual } \\
\text { Surplus } \\
\text { relative to } \\
\text { space need } \\
\text { curve (kgal) } \\
\end{array}$} & \multicolumn{10}{|c|}{$\begin{array}{l}\text { Cumulative IAS by Year and Sorted by Ascending } \\
\text { TIAS (K-Gal) in the Year } 2009\end{array}$} \\
\hline & & & $\begin{array}{l}\text { Year } \\
2000\end{array}$ & $\begin{array}{l}\text { Year } \\
2001\end{array}$ & $\begin{array}{l}\text { Year } \\
2002\end{array}$ & $\begin{array}{l}\text { Year } \\
2003\end{array}$ & $\begin{array}{l}\text { Year } \\
2004\end{array}$ & $\left|\begin{array}{l}\text { Year } \\
2005\end{array}\right|$ & $\left|\begin{array}{l}\text { Year } \\
2006\end{array}\right|$ & $\begin{array}{l}\text { Year } \\
2007\end{array}$ & $\begin{array}{l}\text { Year } \\
2008\end{array}$ & $\begin{array}{l}\text { Year } \\
2009\end{array}$ \\
\hline & & & & & & & & & & & & \\
\hline S-68 & $10,4,72,11$ & & 759 & 1526 & 2276 & 3476 & 3672 & 3868 & 5564 & 5760 & 5956 & 6502 \\
\hline S-69 & $10,4,72,12$ & 674 & 759 & 1526 & 2276 & 3476 & 3672 & 3868 & 5564 & 5760 & 5956 & 6502 \\
\hline$S-70$ & $10,4,72,14$ & 674 & 759 & 1526 & 2276 & 3476 & 3672 & 3868 & 5564 & 5760 & 5956 & 6502 \\
\hline S-71 & $10,4,72,15$ & 674 & 759 & 1526 & 2276 & 3476 & 3672 & 3868 & 5564 & 5760 & 5956 & 6502 \\
\hline$S-72$ & $10,17,24,18,16$ & 1050 & 868 & 3120 & 2950 & 3197 & 3354 & 5051 & 5571 & 6187 & 6293 & 6524 \\
\hline$S-73$ & $10,17,24,21,16$ & 1170 & 868 & 3120 & 2950 & 3197 & 4554 & 5051 & 5571 & 6187 & 6293 & 6524 \\
\hline S-74 & $10,17,24,72,16$ & 1290 & 868 & 3120 & 2950 & 4397 & 4554 & 5051 & 5571 & 6187 & 6293 & 6524 \\
\hline$S-75$ & $10,17,24,69,16$ & & 868 & 3120 & 2950 & 3197 & 4554 & 5051 & 5571 & 6187 & 6293 & 6524 \\
\hline$S-76$ & $10,17,18,16,11$ & 889 & 759 & 2826 & 2826 & 2826 & 3022 & 4796 & 5464 & 6133 & 6329 & 6525 \\
\hline S-77 & $10,17,18,16,12$ & 889 & 759 & 2826 & 2826 & 2826 & 3022 & 4796 & 5464 & 6133 & 63296 & 6525 \\
\hline S-78 & $10,17,18,16,14$ & 89 & 759 & 2826 & 2826 & 2826 & 3022 & 4796 & 5464 & 6133 & 63296 & 6525 \\
\hline S-79 & $10,17,18,16,15$ & 889 & 759 & 2826 & 2826 & 2826 & 3022 & 4796 & 5464 & 6133 & 63296 & 6525 \\
\hline$S-80$ & $10,17,21,16,11$ & 1009 & 759 & 2826 & 2826 & 2826 & 4222 & 4796 & 5464 & 6133 & 63296 & 6525 \\
\hline S-81 & $10,17,21,16,12$ & 1009 & 759 & 2826 & 2826 & 2826 & 4222 & 4796 & 5464 & 6133 & 63296 & 6525 \\
\hline S-82 & $10,17,21,16,14$ & 1009 & 759 & 2826 & 2826 & 2826 & 4222 & 4796 & 5464 & 6133 & 6329 & 6525 \\
\hline $\mathrm{S}-83$ & $10,17,21,16,15$ & 1009 & 759 & 2826 & 2826 & 2826 & 4222 & 4796 & 5464 & 6133 & 6329 & 6525 \\
\hline S-84 & $10,17,72,16,11$ & & 759 & 2826 & 2826 & 4026 & 4222 & 4796 & 5464 & 6133 & 6329 & 6525 \\
\hline S-85 & $10,17,72,1$ & 1129 & 759 & 2826 & 2826 & 4026 & 4222 & 4796 & 5464 & 6133 & 6329 & 6525 \\
\hline S-86 & $10,17,72,16,14$ & 1129 & 759 & 2826 & 2826 & 4026 & 4222 & 4796 & 5464 & 6133 & 6329 & 6525 \\
\hline$S-87$ & $10,17,72$ & & 759 & 2826 & 2826 & 4026 & 4222 & 4796 & 5464 & 6133 & 6329 & 6525 \\
\hline S-88 & $10,17,69,16,11$ & 1009 & 759 & 2826 & 2826 & 2826 & 4222 & 4796 & 5464 & 6133 & \begin{tabular}{|l|}
6329 \\
\end{tabular} & 6525 \\
\hline S-89 & $10,17,69,16,12$ & 1009 & 759 & 2826 & 2826 & 2826 & 4222 & 4796 & 5464 & 6133 & 6329 & 6525 \\
\hline S-90 & $10,17,69,16,14$ & 1009 & 759 & 2826 & 2826 & 2826 & 4222 & 4796 & 5464 & 6133 & 6329 & 6525 \\
\hline S-91 & $10,17,69,16,15$ & 1009 & 759 & 2826 & 2826 & 2826 & 4222 & 4796 & 5464 & 6133 & \begin{tabular}{|l|}
6329 \\
\end{tabular} & 6525 \\
\hline$S-92$ & $10,4,24,17$ & 1165 & 868 & 3120 & 3700 & 3947 & 4104 & 4223 & 5771 & 5914 & 6020 & 6601 \\
\hline S-93 & $10,4,17,11$ & 1004 & 759 & 2826 & 3576 & 3576 & 3772 & 3968 & 5664 & 5860 & 6056 & 6602 \\
\hline S-94 & $10,4,17,12$ & 1004 & 759 & 2826 & 3576 & 3576 & 3772 & 3968 & 5664 & 5860 & 6056 & 6602 \\
\hline S-95 & $10,4,17,14$ & 1004 & 759 & 2826 & 3576 & 3576 & 3772 & 3968 & 5664 & 5860 & 6056 & 6602 \\
\hline S-96 & $10,4,17,15$ & 1004 & 759 & 2826 & 3576 & 3576 & 3772 & 3968 & 5664 & 5860 & 6056 & 6602 \\
\hline S-97 & $10,17,18,4$ & 1193 & 759 & 2826 & 3576 & 3576 & 3576 & 4776 & 6276 & 6276 & 6276 & 6626 \\
\hline S-98 & $10,17,21,4$ & 1313 & 759 & 2826 & 3576 & 3576 & 4776 & 4776 & 6276 & 6276 & 6276 & 6626 \\
\hline S-99 & $10,4,72,17$ & 1433 & 759 & 2826 & 3576 & 4776 & 4776 & 4776 & 6276 & 6276 & 6276 & 6626 \\
\hline$S-100$ & $10,17,69,4$ & 1313 & 759 & 2826 & 3576 & 3576 & 4776 & 4776 & 6276 & 6276 & 6276 & 6626 \\
\hline S-101 & $10,17,22,1$ & 1572 & 759 & 3886 & 3886 & 3886 & 3886 & 3886 & 3886 & 9086 & 8086 & 7086 \\
\hline$S-102$ & $10,22,24,6$ & 989 & 868 & 2880 & 2710 & 2957. & 3114 & 4463 & 5381 & 5984 & \begin{tabular}{|l|}
6960 \\
\end{tabular} & 7191 \\
\hline
\end{tabular}


High Level Waste Tank Space

WSRC-RP-99-00005

Management Team

Revision: 0

Final Report

Page 97 of 135

\begin{tabular}{|c|c|c|c|c|c|c|c|c|c|c|c|c|}
\hline \multirow[t]{2}{*}{$\begin{array}{l}\text { Strategy } \\
\text { Tracking } \\
\text { Number }\end{array}$} & \multirow{2}{*}{$\begin{array}{c}\text { Strategy } \\
\text { (Intermediate } \\
\text { List Ideas and } \\
\text { Sequence of } \\
\text { Implementation) }\end{array}$} & \multirow{2}{*}{$\begin{array}{c}\text { Average } \\
\text { Annual } \\
\text { Surplus } \\
\text { relative to } \\
\text { space need } \\
\text { curve (kgal) } \\
\end{array}$} & \multicolumn{10}{|c|}{$\begin{array}{l}\text { Cumulative IAS by Year and Sorted by Ascending } \\
\text { TIAS (K-Gal) in the Year } 2009\end{array}$} \\
\hline & & & $\begin{array}{l}\text { Year } \\
2000\end{array}$ & $\begin{array}{l}\text { Year } \\
2001\end{array}$ & $\begin{array}{l}\text { Year } \\
2002\end{array}$ & $\begin{array}{l}\text { Year } \\
2003\end{array}$ & $\begin{array}{l}\text { Year } \\
2004\end{array}$ & $\mid \begin{array}{l}\text { Year } \\
2005\end{array}$ & $\begin{array}{l}\text { Year } \\
2006\end{array}$ & $\begin{array}{l}\text { Year } \\
2007\end{array}$ & $\begin{array}{l}\text { Year } \\
2008\end{array}$ & $\begin{array}{l}\text { Year } \\
2009\end{array}$ \\
\hline & & & & & & & & & & & & \\
\hline S-103 & $10,22,24,7$ & 989 & 868 & \begin{tabular}{l|l|}
8 & 2880 \\
\end{tabular} & 2710 & 2957 & 3114 & 4463 & 5381 & 5984 & 6960 & 7191 \\
\hline S-104 & $10,17,18,1$ & 1218 & 759 & 92826 & 2826 & 2826 & 2826 & 4026 & 4026 & 9226 & 8226 & 7226 \\
\hline S-105 & $10,17,21,1$ & 1338 & 759 & $\begin{array}{l}92826 \\
\end{array}$ & 2826 & 2826 & 4026 & 4026 & 4026 & 9226 & 8226 & 7226 \\
\hline S-106 & $10,17,72,1$ & 1458 & 759 & 2826 & 2826 & 4026 & 4026 & 4026 & 4026 & 9226 & 8226 & 7226 \\
\hline S-107 & $10,17,69,1$ & 1338 & 759 & 2826 & 2826 & 2826 & 4026 & 4026 & 4026 & 9226 & 8226 & 7226 \\
\hline S-108 & $10,3,22,24$ & 1064 & 868 & 2880 & 3460 & 3707 & 3864 & 3983 & 5531 & 5674 & 5780 & 7511 \\
\hline S-109 & $10,3,22,11$ & 903 & 759 & 2586 & 3336 & 3336 & 3532 & 3728 & 5424 & 5620 & 5816 & 7512 \\
\hline$S-110$ & $10,3,22,12$ & 903 & 759 & 2586 & 3336 & 3336 & 3532 & 3728 & 5424 & 5620 & 5816 & 7512 \\
\hline$S-111$ & $10,3,22,14$ & 903 & 759 & 2586 & 3336 & 3336 & 3532 & 3728 & 5424 & 5620 & 5816 & 7512 \\
\hline S-112 & $10,3,22,15$ & 903 & 759 & 2586 & 3336 & 3336 & 3532 & 3728 & 5424 & 5620 & 5816 & 7512 \\
\hline$S-113$ & $10,4,5$ & 1227 & 1044 & 2200 & 3178 & 3570 & 3872 & 4178 & 6115 & 6480 & 6731 & 7519 \\
\hline S-114 & $10,3,22,18$ & 1092 & 759 & 2586 & 3336 & 3336 & 3336 & 4536 & 6036 & 6036 & 6036 & 7536 \\
\hline S-115 & $10,3,22,21$ & 1212 & 759 & 2586 & 3336 & 3336 & 4536 & 4536 & 6036 & 6036 & 6036 & 7536 \\
\hline$S-116$ & $10,3,22,72$ & 1332 & 759 & 2586 & 3336 & 4536 & 4536 & 4536 & 6036 & 6036 & 6036 & 7536 \\
\hline S-117 & $10,3,22,69$ & 1212 & 759 & 2586 & 3336 & 3336 & 4536 & 4536 & 6036 & 6036 & 6036 & 7536 \\
\hline S-118 & $10,3,22,17$ & 1662 & 759 & 3886 & 4636 & 4636 & 4636 & 4636 & 6136 & 6136 & 6136 & 7636 \\
\hline S-119 & $10,3,24,18$ & 710 & 868 & 1820 & 2400 & 2647 & 2804 & 4123 & 5671 & 5814 & 5920 & 7651 \\
\hline$S-120$ & $10,3,24,21$ & 830 & 868 & 1820 & 2400 & 2647 & 4004 & 4123 & 5671 & 5814 & 5920 & 7651 \\
\hline$S-121$ & $10,3,24,72$ & 950 & 868 & 1820 & 2400 & 3847 & 4004 & 4123 & 5671 & 5814 & 5920 & 7651 \\
\hline$S-122$ & $10,3,24,69$ & 830 & 868 & 1820 & 2400 & 2647 & 4004 & 4123 & 5671 & 5814 & 5920 & 7651 \\
\hline $\mathrm{S}-123$ & $10,3,72,11$ & 789 & 759 & 1526 & 2276 & 3476 & 3672 & 3868 & 5564 & 5760 & 5956 & 7652 \\
\hline$S-124$ & $10,3,72,12$ & 789 & 759 & 1526 & 2276 & 3476 & 3672 & 3868 & 5564 & 5760 & 5956 & 7652 \\
\hline S-125 & $10,3,72,14$ & 789 & 759 & 1526 & 2276 & 3476 & 3672 & 3868 & 5564 & 5760 & 5956 & 7652 \\
\hline S-126 & $10,3,72,15$ & 789 & 759 & 1526 & 2276 & 3476 & 3672 & 3868 & 5564 & 5760 & 5956 & 7652 \\
\hline$S-127$ & $10,3,22,16$ & 1011 & 759 & 2586 & 3336 & 3336 & 3336 & 3714 & 5686 & 6159 & 6159 & 7659 \\
\hline $\mathrm{S}-128$ & $10,3,24,17$ & 1280 & 868 & 3120 & 3700 & 3947 & 4104 & 4223 & 5771 & 5914 & 6020 & 7751 \\
\hline$S-129$ & $10,3,17,11$ & 1119 & 759 & 2826 & 3576 & 3576 & 3772 & 3968 & 5664 & 5860 & 6056 & 7752 \\
\hline$S-130$ & $10,3,17,12$ & 1119 & 759 & 2826 & 3576 & 3576 & 3772 & 3968 & 5664 & 5860 & 6056 & 7752 \\
\hline$S-131$ & $10,3,17,14$ & 1119 & 759 & 2826 & 3576 & 3576 & 3772 & 3968 & 5664 & 5860 & 6056 & 57752 \\
\hline$S-132$ & $10,3,17,15$ & 1119 & 759 & 2826 & 3576 & 3576 & 3772 & 3968 & 5664 & 5860 & 6056 & 7752 \\
\hline$S-133$ & $10,17,18,3$ & 1308 & 759 & 2826 & 3576 & 3576 & 3576 & 4776 & 6276 & 6276 & 6276 & 57776 \\
\hline S-134 & $10,17,21,3$ & 1428 & 759 & 2826 & 3576 & 3576 & 4776 & 4776 & 6276 & 6276 & 6276 & 57776 \\
\hline S-135 & $10,3,72,17$ & 1548 & 759 & 2826 & 3576 & 4776 & 4776 & 4776 & 6276 & 6276 & 6276 & 7776 \\
\hline$S-136$ & $10,17,69,3$ & 1428 & 759 & 2826 & 3576 & 3576 & 4776 & 4776 & 6276 & 6276 & 6276 & 7776 \\
\hline S-137 & $10,3,72,16$ & 897 & 759 & 1526 & 2276 & 3476 & 3476 & 3854 & 5826 & 6299 & 6299 & 7799 \\
\hline
\end{tabular}


High Level Waste Tank Space

Management Team

Final Report
WSRC-RP-99-00005

Revision: 0

Page 98 of 135

\begin{tabular}{|c|c|c|c|c|c|c|c|c|c|c|c|c|}
\hline \multirow[t]{2}{*}{$\begin{array}{l}\text { Strategy } \\
\text { Tracking } \\
\text { Number }\end{array}$} & \multirow{2}{*}{$\begin{array}{c}\text { Strategy } \\
\text { (Intermediate } \\
\text { List Ideas and } \\
\text { Sequence of } \\
\text { Implementation) }\end{array}$} & \multirow{2}{*}{$\begin{array}{l}\text { Average } \\
\text { Annual } \\
\text { Surplus } \\
\text { relative to } \\
\text { space need } \\
\text { curve (kgal) } \\
\end{array}$} & \multicolumn{10}{|c|}{$\begin{array}{c}\text { Cumulative IAS by Year and Sorted by Ascending } \\
\text { TIAS (K-Gal) in the Year } 2009\end{array}$} \\
\hline & & & $\begin{array}{l}\text { Year } \\
2000\end{array}$ & $\begin{array}{l}\text { Year } \\
2001\end{array}$ & $\left|\begin{array}{l}\text { Year } \\
2002\end{array}\right|$ & $\begin{array}{l}\text { Year } \\
2003\end{array} \mid$ & $\left|\begin{array}{l}\text { Year } \\
2004\end{array}\right|$ & $\begin{array}{l}\text { Year } \\
2005\end{array}$ & $\begin{array}{l}\text { Year } \\
2006\end{array}$ & $\begin{array}{l}\text { Year } \\
2007\end{array}$ & $\begin{array}{l}\text { Year } \\
2008\end{array}$ & $\begin{array}{l}\text { Year } \\
2009\end{array}$ \\
\hline & $0,3,17,16$ & & 759 & 2826 & 3576 & 3576 & 3576 & 3954 & 5926 & 6399 & 6399 & 899 \\
\hline S-139 & $10,22,24,18,1$ & 1574 & 868 & 2880 & 2710 & 2957 & 3114 & 4433 & 4481 & 9824 & 8930 & 8161 \\
\hline$S-140$ & $10,22,21,24,1$ & 1694 & 868 & 2880 & 2710 & 2957 & 4314 & 4433 & 4481 & 9824 & 8930 & 8161 \\
\hline$S-141$ & $10,22,72,24,1$ & 1814 & 868 & 2880 & 2710 & 4157 & 4314 & 4433 & 4481 & 9824 & 8930 & 8161 \\
\hline S-142 & $10,22,69,24,1$ & 1694 & 868 & 2880 & 2710 & 2957 & 4314 & 4433 & 4481 & 9824 & 8930 & 8161 \\
\hline$S-143$ & $10,22,21,11,1$ & 1533 & 759 & 2586 & 2586 & 2586 & 3982 & 4178 & 4374 & 9770 & 8966 & 8162 \\
\hline$S-144$ & $10,22,21,12,1$ & 1533 & 759 & 2586 & 2586 & 2586 & 3982 & 4178 & 4374 & 9770 & 8966 & 8162 \\
\hline$S-145$ & $10,22,21,14,1$ & & 759 & 2586 & 2586 & 2586 & 3982 & 4178 & 4374 & 9770 & 8966 & 8162 \\
\hline S-146 & $10,22,21,15,1$ & 1533 & 759 & 2586 & 2586 & 2586 & 3982 & 4178 & 4374 & 9770 & 8966 & 8162 \\
\hline S-147 & $10,22,72,11,1$ & 1653 & 759 & 2586 & 2586 & 3786 & 3982 & 4178 & 4374 & 9770 & 8966 & 8162 \\
\hline S-148 & $10,22,72,12,1$ & 1653 & 759 & 2586 & 2586 & 3786 & 3982 & 4178 & 4374 & 9770 & 8966 & 8162 \\
\hline S-149 & $10,22,72,14,1$ & 1653 & 759 & 2586 & 2586 & 3786 & 3982 & 4178 & 4374 & 9770 & 8966 & 8162 \\
\hline$S-150$ & $10,22,72,15,1$ & 1653 & 759 & 2586 & 2586 & 3786 & 3982 & 4178 & 4374 & 9770 & 8966 & 8162 \\
\hline S-151 & $10,22,69,1$ & & 759 & 2586 & 2586 & 2586 & 3982 & 4178 & 4374 & 9770 & 8966 & 8162 \\
\hline S-152 & $10,22,69,12,1$ & 1533 & 759 & 2586 & 2586 & 2586 & 3982 & 4178 & 4374 & 9770 & 8966 & 8162 \\
\hline $\mathrm{S}-153$ & $10,22,69,14,1$ & 1533 & 759 & 2586 & 2586 & 2586 & 3982 & 4178 & 4374 & 9770 & 8966 & 8162 \\
\hline S-154 & $10,22,69,15,1$ & & 759 & 2586 & 2586 & 2586 & 3982 & 4178 & 4374 & 9770 & 8966 & 8162 \\
\hline$S-155$ & $10,22,24,16,1$ & 1494 & 868 & 2880 & 2710 & 2957 & 3114 & 3611 & 4131 & 9947 & 9053 & 8284 \\
\hline S-156 & $10,22,21,16,1$ & 1641 & 759 & 2586 & 2586 & 2586 & 3786 & 4164 & 4636 & 10309 & 9309 & 8309 \\
\hline S-157 & $10,22,72,16,1$ & 1761 & 759 & 2586 & 2586 & 3786 & 3786 & 4164 & 4636 & 10309 & 9309 & 8309 \\
\hline$S-158$ & $10,22,69,16,1$ & 1641 & 759 & 2586 & 2586 & 2586 & 3786 & 4164 & 4636 & 10309 & 9309 & 8309 \\
\hline$\cdot S-159$ & $10,5,6$ & 1267 & 1044 & 2200 & 2428 & 2820 & 3122 & 4658 & 5965 & 6790 & 7911 & 8349 \\
\hline$S-160$ & $10,5,7$ & 1267 & 1044 & 2200 & 2428 & 2820 & 3122 & 4658 & 5965 & 6790 & 7911 & 8349 \\
\hline$S-161$ & $10,17,24,16,1$ & 1710 & 868 & 3120 & 2950 & 3197 & 3354 & 3851 & 4371 & 10187 & 9293 & 8524 \\
\hline S-162 & $10,17,11,16,1$ & 1549 & 759 & 2826 & 2826 & 2826 & 3022 & 3596 & 4264 & 10133 & 9329 & 8525 \\
\hline S-163 & $10,17,12,16,1$ & 1549 & 759 & 2826 & 2826 & 2826 & 3022 & 3596 & 4264 & 10133 & 9329 & 8525 \\
\hline S-164 & $10,17,14,16,1$ & 1549 & 759 & 2826 & 2826 & 2826 & 3022 & 3596 & 4264 & 10133 & 9329 & 8525 \\
\hline S-165 & $10,17,15,16,1$ & 1549 & 759 & 2826 & 2826 & 2826 & 3022 & 3596 & 4264 & 10133 & 9329 & 8525 \\
\hline$S-166$ & $10,4,72,1$ & 1523 & 759 & 1526 & 2276 & 3476 & 3476 & 3476 & 4976 & 10176 & 9176 & 8526 \\
\hline S-167 & $10,4,22,6$ & 1652 & 759 & 2586 & 3336 & 3336 & 3336 & 4566 & 6936 & 7396 & 8266 & 8616 \\
\hline S-168 & $10,4,22,7$ & 1652 & 759 & 2586 & 3336 & 3336 & 3336 & 4566 & 6936 & 7396 & 8266 & 8616 \\
\hline$S-169$ & $10,4,17,1$ & 1853 & 759 & 2826 & 3576 & 3576 & 3576 & 3576 & 5076 & 10276 & 9276 & 8626 \\
\hline$S-170$ & $10,3,5$ & 1342 & 1044 & 2200 & 3178 & 3570 & 3872 & 4178 & 6115 & 6480 & 6731 & 8669 \\
\hline S-171 & $10,4,24,6$ & 1270 & 868 & 1820 & 2400 & 2647 & 2804 & 4153 & 6571 & 7174 & 8150 & 8731 \\
\hline$S-172$ & $10,4,24,7$ & 1270 & 868 & 1820 & 2400 & 2647 & 2804 & 4153 & 6571 & 7174 & 8150 & 8731 \\
\hline
\end{tabular}




\begin{tabular}{|c|c|c|c|c|c|c|c|c|c|c|c|c|}
\hline \multirow{2}{*}{$\begin{array}{l}\text { Strategy } \\
\text { Tracking } \\
\text { Number }\end{array}$} & \multirow{2}{*}{$\begin{array}{c}\text { Strategy } \\
\text { (Intermediate } \\
\text { List Ideas and } \\
\text { Sequence of } \\
\text { Implementation) }\end{array}$} & \multirow{2}{*}{$\begin{array}{c}\text { Average } \\
\text { Annual } \\
\text { Surplus } \\
\text { relative to } \\
\text { space need } \\
\text { curve (kgal) }\end{array}$} & \multicolumn{10}{|c|}{$\begin{array}{c}\text { Cumulative IAS by Year and Sorted by Ascending } \\
\text { TIAS (K-Gal) in the Year } 2009\end{array}$} \\
\hline & & & $\begin{array}{l}\text { Year } \\
2000\end{array}$ & $\begin{array}{l}\text { Year } \\
2001\end{array}$ & $\begin{array}{l}\text { Year } \\
2002\end{array}$ & $\begin{array}{l}\text { Year } \\
2003\end{array}$ & $\begin{array}{l}\text { Year } \\
2004\end{array}$ & $\begin{array}{l}\text { Year } \\
2005\end{array}$ & $\begin{array}{l}\text { Year } \\
2006\end{array}$ & $\begin{array}{l}\text { Year } \\
2007\end{array}$ & $\begin{array}{l}\text { Year } \\
2008\end{array}$ & $\begin{array}{l}\text { Year } \\
2009\end{array}$ \\
\hline$S-173$ & & & 1044 & 3260 & 3488 & 3880 & 4182 & 14488 & 4925 & 10490 & 0741 & $91^{\circ}$ \\
\hline S-174 & $10,3,72,1$ & 1638 & 759 & 1526 & 2276 & 3476 & 3476 & 3476 & 4976 & 10176 & 9176 & 9676 \\
\hline S-175 & $10,3,22,6$ & 1767 & 759 & 2586 & 3336 & 3336 & 3336 & 4566 & 6936 & 7396 & 8266 & 9766 \\
\hline$S-176$ & $10,3,22,7$ & 1767 & 759 & 2586 & 3336 & 3336 & 3336 & 4566 & 6936 & 7396 & 8266 & 9766 \\
\hline S-177 & $10,3,17,1$ & 1968 & 759 & 2826 & 3576 & 3576 & 3576 & 3576 & 5076 & 10276 & 9276 & 9776 \\
\hline S-178 & $10,3,24,6$ & 1385 & 868 & 1820 & 2400 & 2647 & 2804 & 4153 & 6571 & 7174 & 8150 & 9881 \\
\hline S-179 & $10,3,24,7$ & 1385 & 868 & 1820 & 2400 & 2647 & 2804 & 4153 & 6571 & 7174 & 8150 & 9881 \\
\hline
\end{tabular}




\subsection{Strategy Down-Selection}

The process to evaluate and reduce the 179 Strategies identified in Section 8.0 to an overall Strategy is described in this section. The Strategy is designed to manage HLW tank space during the period from the present until 2009 when the Alternative Salt Facility begins to process salt solutions. The down-selection process used is shown in Figure 9-1, and is defined in the desktop procedure entitled "HLW Tank Space Strategy Selection Process." 6

\section{$9.1 \quad$ Stage 1 Selection}

The process used to reduce the number of Strategies from 179 to 18 is described in this section.

\subsubsection{Development of Strategy Weighting}

Multi-Attribute Utility Analysis (weighted evaluation criteria) (MAUA) was used to evaluate and rank the 179 identified Strategies. Weighted evaluation criteria and associated utility functions were used to provide a consistent ranking of the Strategies. The evaluation criteria, definitions, and relative weighting for each criterion are described in Table 9-1. The utility functions defined for each criterion and the utility function values assigned are provided in Table 9-2.

Utility functions are used to objectively evaluate Strategies against each weighted criterion by establishing a "measurable range of desirability." Each Strategy was evaluated against each attribute by determining the utility function that best describes that attribute for each Strategy. The utility function values assigned to each Strategy are multiplied by the attribute weight and summed arithmetically to provide a numerical score for each Strategy.

\subsubsection{Approval of Weighting Criteria}

The HLW Salt Disposition Program Manager concurred ${ }^{10}$ with the SM Team's recommended evaluation criteria, weights, utility functions and associated utility function values presented on Tables 9-1 and 9-2 before they were used.

\subsubsection{Sensitivity Analysis}

The Level 1 and Level 2 weighted evaluation criteria, shown in Table 9-2, were tested for sensitivity to small $( \pm 20 \%)$ changes. The details of this analysis are provided in Reference 11 and concluded that the criteria were insensitive to change unless these changes exceeded $\pm 20 \%$. 
DOWN SELECT

FROM 179 TO 18

STRATEGIES

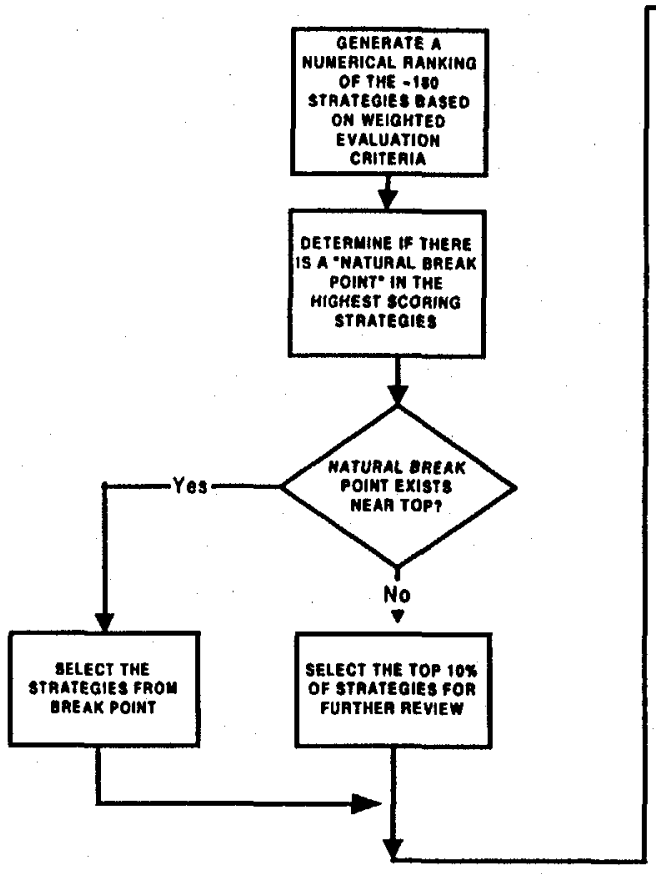

DOWN SELECT FROM 18 TO 4 STRATEGIES

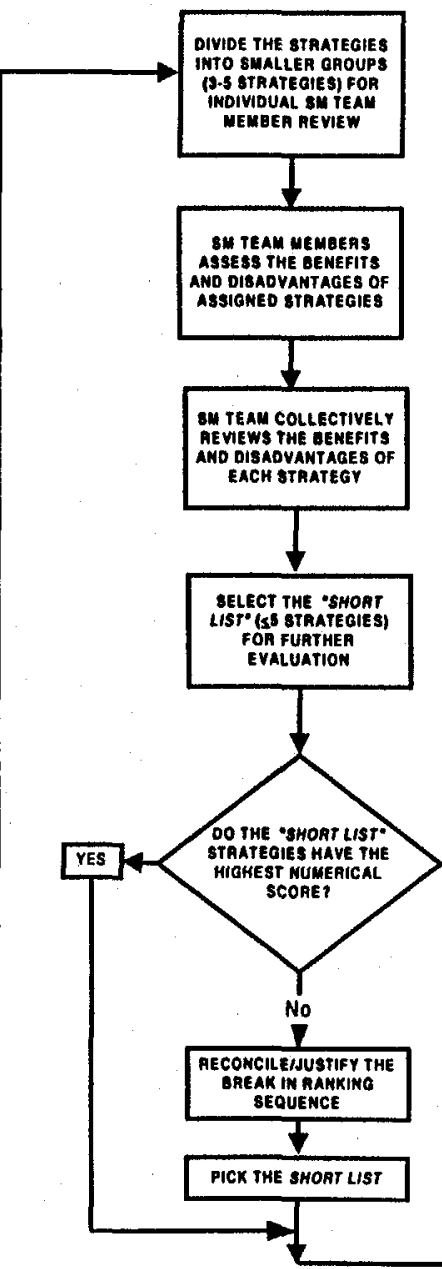

DOWN SELECT

FROM 4 TO 1

STRATEGIES

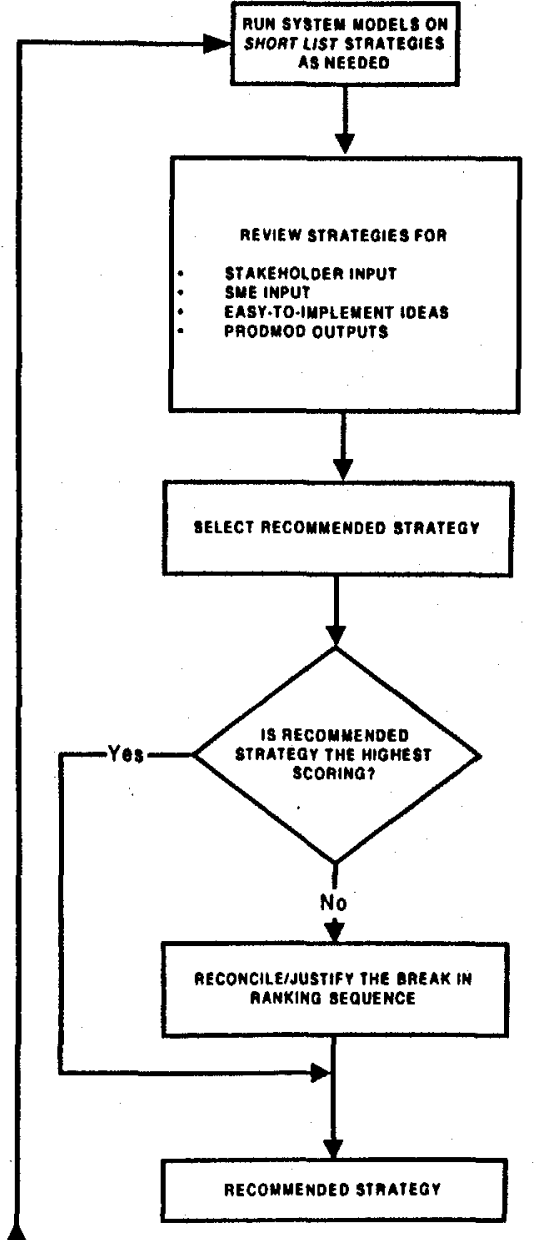

Figure 9-1: Multi-Stage Strategy Down-selection Process 
High Level Waste Tank Space

WSRC-RP-99-00005

Management Team

Revision: 0

Final Report

Page 102 of 135

\section{THIS PAGE INTENTIONALLY LEFT BLANK}


Table 9-1: HLW Tank Space Management Team Level 1 and Level 2 Evaluation Criteria, Assigned Weights, and Definitions

\begin{tabular}{|c|r|r|l|}
\hline Criterion Title & $\begin{array}{c}\text { Criterion } \\
\text { No. }\end{array}$ & $\begin{array}{c}\text { Assigned } \\
\text { Weight }\end{array}$ & \multicolumn{1}{|c|}{ Definition } \\
\hline $\begin{array}{c}\text { Strategy Exceeds Available } \\
\text { Space Baseline }\end{array}$ & 1.0 & $10 \%$ & $\begin{array}{l}\text { The degree to which the Strategy's annual Increase } \\
\text { in Available Space (IAS) exceeds minimum } \\
\text { required IAS in the “Available Space Baseline for } \\
\text { Space Management Team Initiative", Revision } 2 .\end{array}$ \\
\hline Impact on Site Missions & 2.0 & $30 \%$ & $\begin{array}{l}\text { The degree to which the Strategy supports } \\
\text { operation of DWPF and closure of waste } \\
\text { tanks. }\end{array}$ \\
\hline DWPF Canister Production & 2.1 & $50 \%$ & $\begin{array}{l}\text { The degree to which the Strategy supports DWPF } \\
\text { canister production, expressed as canisters per year. }\end{array}$ \\
\hline $\begin{array}{c}\text { Compatibility with Existing } \\
\text { HLW Processes }\end{array}$ & 3.0 & $30 \%$ & $\begin{array}{l}\text { The degree to which the Strategy uses existing } \\
\text { HLW and SRS infrastructure and permits. }\end{array}$ \\
\hline Use of Existing Facilities & 2.2 & $50 \%$ & $\begin{array}{l}\text { The number of HLW tanks that could be closed by } \\
\text { HL11.* }\end{array}$ \\
\hline Operational Simplicity & 3.1 & $20 \%$ & $\begin{array}{l}\text { The degree to which existing facilities are used for } \\
\text { their intended function(s). }\end{array}$ \\
\hline Regulatory Impacts & 3.2 & $40 \%$ & $\begin{array}{l}\text { The extent to which a Strategy can be accomplished } \\
\text { using simple, manageable operations. }\end{array}$ \\
\hline $\begin{array}{l}\text { Cost } \\
\text { Implementing a Strategy }\end{array}$ & 3.3 & $40 \%$ & $\begin{array}{l}\text { The degree to which the Strategy uses existing } \\
\text { permits. (FFA, STP, IWWP, etc.) }\end{array}$ \\
\hline
\end{tabular}

* The 2011 date was selected to show the number of HLW Tanks that will be emptied and would be available for start of closure activities in 2009. 
Table 9-2: Utility Functions

\begin{tabular}{|c|c|c|c|c|c|}
\hline $\begin{array}{l}\text { LEVEL } 1 \\
\text { CRITERION }\end{array}$ & $\begin{array}{l}\text { LEVEL 1 } \\
\text { WEIGHT }\end{array}$ & $\begin{array}{c}\text { LEVEL } 2 \\
\text { CRITERION }\end{array}$ & $\begin{array}{l}\text { LEVEL } 2 \\
\text { WEIGHT }\end{array}$ & UTILITY FUNCTION & $\begin{array}{l}\text { UTILITY } \\
\text { FUNCTION } \\
\text { VALUE }\end{array}$ \\
\hline $\begin{array}{l}1.0 \\
\text { (Strategy } \\
\text { exceeds } \\
\text { available space } \\
\text { baseline) }\end{array}$ & (.10) & None & N/A & $\begin{array}{l}\text { Note: Average annual excess calculated by summing the excess for each } \\
\text { year in the 10-year period and then dividing the sum by } 10 . \\
\text { UF.1 - Largest increase beyond available space baseline requirements. } \\
\text { UF.2 - } \quad \text { Linearly Interpolate between UF.1 and UF.3\}. } \\
\text { UF.3 - Meets available space baseline requirements. }\end{array}$ & $\begin{array}{l}100 \\
\text { Interpolated } \\
0\end{array}$ \\
\hline \multirow{3}{*}{$\begin{array}{l}2.0 \\
\text { (Impact on site } \\
\text { missions) }\end{array}$} & \multirow[t]{3}{*}{$(.30)$} & & & See below. & \\
\hline & & $\begin{array}{l}2.1 \\
\text { (DWPF } \\
\text { canister } \\
\text { production) }\end{array}$ & $(.50)$ & $\begin{array}{l}\text { UF.1 - Average DWPF production yields } 200 \text { canisters per year. } \\
\text { UF.2 - } \\
\text { UF.3 - }\end{array}$ & $\begin{array}{c}100 \\
62 \\
0\end{array}$ \\
\hline & & $\begin{array}{l}2.2 \\
\text { (HLW tank } \\
\text { closure) }\end{array}$ & $(.50)$ & $\begin{array}{l}\text { UF.1 - Most number of tanks closed (17). } \\
\text { UF.2 - } \quad \text { (Linearly Interpolate between UF.1 and UF.3\} } \\
\text { UF.3 - Five (5) tanks closed. } \\
\text { UF.4 - } \quad \text { (Linearly Interpolate between UF.3 and UF.5\} } \\
\text { UF.5 - Zero (0) tanks closed. }\end{array}$ & $\begin{array}{l}100 \\
\text { Interpolated } \\
10 \\
\text { Interpolated } \\
0\end{array}$ \\
\hline
\end{tabular}


Table 9-2: Utility Functions (Cont.)

\begin{tabular}{|c|c|c|c|c|c|}
\hline $\begin{array}{c}\text { LEVEL } 1 \\
\text { CRITERION }\end{array}$ & $\begin{array}{l}\text { LEVEL } 1 \\
\text { WEIGHT }\end{array}$ & $\begin{array}{c}\text { LEVEL } 2 \\
\text { CRITERION }\end{array}$ & $\begin{array}{l}\text { LEVEL } 2 \\
\text { WEIGHT }\end{array}$ & UTILITY FUNCTION & $\begin{array}{c}\text { UTILITY } \\
\text { FUNCTION } \\
\text { VALUE } \\
\end{array}$ \\
\hline \multirow{4}{*}{$\begin{array}{l}\text { 3.0 } \\
\text { (Compatibility } \\
\text { with existing } \\
\text { HLW } \\
\text { processes) }\end{array}$} & \multirow[t]{4}{*}{$(.30)$} & & & See Below. & \\
\hline & & $\begin{array}{c}3.1 \\
\text { (use of } \\
\text { existing } \\
\text { facilities) }\end{array}$ & $(.20)$ & $\begin{array}{l}\text { UF.1 - Existing facilities account for } 100 \% \text { of increase in available space. } \\
\text { UF.2 - Existing facilities account for } 80 \% \text { of increase in available space. } \\
\text { UF.3 - Existing facilities account for } 60 \% \text { of increase in available space. } \\
\text { UF.4 - Existing facilities account for } 40 \% \text { of increase in available space. } \\
\text { UF.5 - Existing facilities account for } 20 \% \text { of increase in available space. } \\
\text { UF.6- Existing facilities account for } 0 \% \text { of increase in available space. }\end{array}$ & $\begin{array}{l}100 \\
80 \\
60 \\
40 \\
20 \\
0\end{array}$ \\
\hline & & $\begin{array}{l}3.2 \\
\text { (operational } \\
\text { simplicity) }\end{array}$ & $(.40)$ & $\begin{array}{l}\text { UF.1 - Design allows for simple, coordinated, straightforward operation. } \\
\text { UF.2 - Design allows for manageable operation with minimal complexity } \\
\text { (standard SRS practice). } \\
\text { UF.3 - Design is highly coupled with minimum holdup, multiple parallel } \\
\text { operations, fast dynamics, and process instability. }\end{array}$ & $\begin{array}{l}100 \\
60 \\
0\end{array}$ \\
\hline & & $\begin{array}{l}3.3 \\
\text { (regulatory } \\
\text { impacts) }\end{array}$ & $(.40)$ & $\begin{array}{l}\text { UF.1 - Some discussions with Regulators may be required, but no permit } \\
\text { or changes to permits required. } \\
\text { UF.2 - Permit(s) change(s) required. } \\
\text { UF.3 - New permit(s) required. }\end{array}$ & $\begin{array}{l}100 \\
20 \\
0\end{array}$ \\
\hline $\begin{array}{l}4.0 \\
(\text { Cost })\end{array}$ & $(.10)$ & None & N/A & $\begin{array}{l}\text { UF.1 - Cost falls within } \$ 0-\$ 1.5 \mathrm{~B} . \\
\text { UF.2 - Cost falls within } \$ 1.5 \mathrm{~B} \text { to } \$ 3.5 \mathrm{~B} \\
\text { UF.3 - Cost }>\$ 3.5 \mathrm{~B}\end{array}$ & $\begin{array}{c}100 \\
50 \\
0\end{array}$ \\
\hline $\begin{array}{l}\mathbf{5 . 0} \\
\text { (Total risk of } \\
\text { implementing } \\
\text { a Strategy) }\end{array}$ & $(.20)$ & None & N/A & $\begin{array}{l}\text { NOTE: } \begin{array}{l}\text { Risk Score }=4 \text { times the number of moderate risks + the number } \\
\text { of low risks. }\end{array} \\
\text { UF.1 - Strategy with lowest risk score calculated as noted above (S-1). } \\
\text { UF.2 - } \quad \text { Linearly Interpolate between UF.1 and UF.3\}. } \\
\text { UF.3 - Strategy with highest risk score (S-124). }\end{array}$ & $\begin{array}{l}100 \\
\text { Interpolated } \\
0\end{array}$ \\
\hline
\end{tabular}




\subsubsection{Strategy Ranking}

The results from applying the MAUA to the 179 Strategies shown in Table 9-1 were determined and the 179 Strategies were then ranked in decreasing order of total score. A plot of these scores in decreasing order is shown on Figure 9-2. Reference 17 contains a detailed listing of each Strategy and the individual attribute scores for each of the weighted evaluation criteria that add up to the total scores represented in Figure 9-2. The total scores ranged from approximately 35 to 80 points.

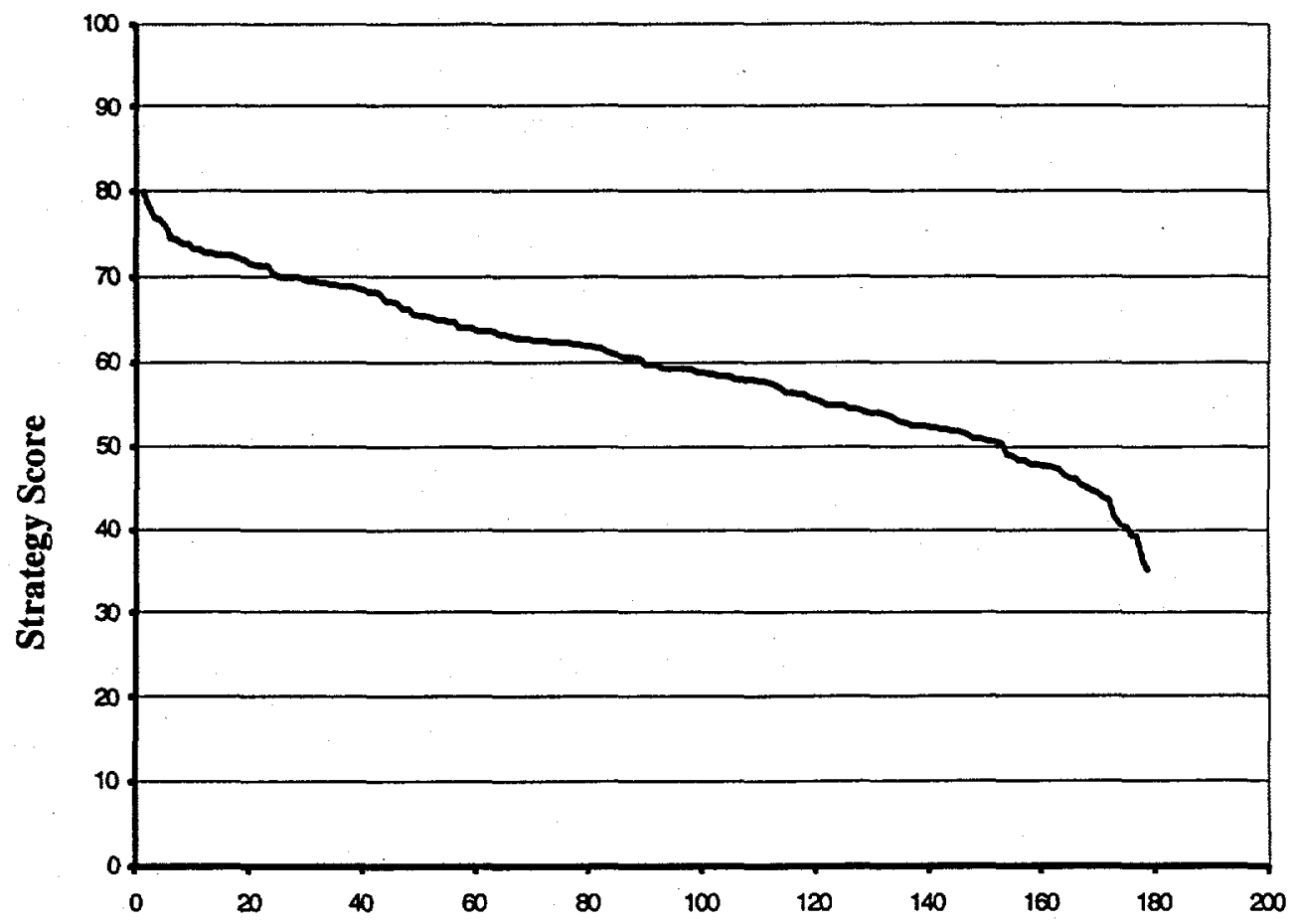

Rank Number

Figure 9-2: Ranked Scores of 179 Strategies

\subsubsection{Selection of Top Eighteen (18) Strategies}

As can be seen from Figure 9-2, there is no natural break in the data, so the SM Team selected the top $10 \%$ or eighteen Strategies for further evaluation. These top eighteen Strategies are shown on Table 9-3 along with the individual attribute scores and their total score in descending order. 
Table 9-3: Top 18 Strategies

\begin{tabular}{|c|c|c|c|c|c|c|c|c|c|c|c|}
\hline $\begin{array}{l}\text { Rank } \\
\text { No. }\end{array}$ & \begin{tabular}{|} 
Strategy \\
No.
\end{tabular} & $\begin{array}{c}\text { Intermediate } \\
\text { List } \\
\text { Ideas Included } \\
\text { in Strategies }\end{array}$ & \begin{tabular}{|c|} 
TIAS \\
Exceeds \\
Space \\
Baseline \\
Criterion \\
1.0 \\
\end{tabular} & \begin{tabular}{|c|} 
Impact on \\
DWPF \\
Canister \\
Production \\
Criterion \\
2.1 \\
\end{tabular} & \begin{tabular}{|c|} 
Impact on \\
Tank \\
Closures \\
Criterion \\
2.2 \\
\end{tabular} & \begin{tabular}{|c|} 
Use of \\
Existing \\
HLW \\
Facilities \\
Criterion \\
3.1 \\
\end{tabular} & \begin{tabular}{|c|} 
Operational \\
Simplicity \\
Criterion \\
3.2 \\
\end{tabular} & \begin{tabular}{|c|} 
Regulatory \\
Impacts \\
Criterion \\
$\mathbf{3 . 3}$ \\
\end{tabular} & \begin{tabular}{|c|} 
Cost \\
Criterion \\
4.0 \\
\end{tabular} & $\begin{array}{c}\text { Risk } \\
\text { Criterion } \\
5.0 \\
\end{array}$ & $\begin{array}{l}\text { Total } \\
\text { Score } \\
\end{array}$ \\
\hline 1 & S-101 & $10,17,22,1$ & \begin{tabular}{|l|}
6.26 \\
\end{tabular} & 15.00 & 15.00 & 3.29 & 8.95 & 6.58 & \begin{tabular}{|l|}
10.00 \\
\end{tabular} & 15.29 & 80.37 \\
\hline 2 & $S-104$ & $10,17,18,1$ & 4.17 & 15.00 & 15.00 & 3.34 & 8.21 & 5.09 & 10.00 & 17.65 & 78.46 \\
\hline 3 & S-105 & $10,17,21,1$ & 4.87 & 15.00 & 15.00 & 3.19 & 9.01 & 4.69 & 10.00 & 15.29 & 77.07 \\
\hline 4 & S-107 & $10,17,69,1$ & 4.87 & 15.00 & 15.00 & 2.84 & 9.01 & 4.69 & 10.00 & 15.29 & 76.72 \\
\hline 5 & S-13 & $10,17,22,11,18$ & 4.79 & 15.00 & 10.09 & 5.32 & 10.08 & 7.91 & 10.00 & 12.65 & 75.84 \\
\hline 6 & S-59 & $10,17,22,16,18$ & 5.43 & 15.00 & 10.09 & 5.88 & 7.65 & 7.73 & 10.00 & 12.94 & 74.71 \\
\hline 7 & $\mathrm{~S}-17$ & $10,17,22,11,21$ & 5.50 & 15.00 & 10.09 & 5.15 & 11.00 & 7.45 & 10.00 & 10.29 & 74.48 \\
\hline 8 & $\mathrm{~S}-25$ & $10,17,22,11,69$ & 5.50 & 15.00 & 10.09 & 4.75 & 11.00 & 7.45 & 10.00 & 10.29 & 74.08 \\
\hline 9 & S-15 & $10,17,22,14,18$ & 4.79 & 15.00 & 10.09 & 5.21 & 9.18 & 7.91 & 10.00 & 11.76 & 73.95 \\
\hline 10 & $S-60$ & $10,17,22,16,21$ & 6.14 & 15.00 & 10.09 & 5.71 & 8.55 & 7.28 & 10.00 & 10.59 & 73.35 \\
\hline 11 & S-143 & $10,22,21,11,1$ & 6.03 & 15.00 & 15.00 & 3.00 & 10.12 & 3.80 & 10.00 & 10.29 & 73.24 \\
\hline 12 & S-62 & $10,17,22,16,69$ & 6.14 & 15.00 & 10.09 & 5.31 & 8.55 & 7.28 & 10.00 & 10.59 & 72.95 \\
\hline 13 & S-151 & $10,22,69,11,1$ & 6.03 & 15.00 & 15.00 & 2.69 & 10.12 & 3.80 & 10.00 & 10.29 & 72.93 \\
\hline 14 & S-106 & $10,17,72,1$ & 5.58 & 15.00 & 13.77 & 3.34 & 8.21 & 5.09 & 10.00 & 11.76 & 72.77 \\
\hline 15 & $S-156$ & $10,22,21,16,1$ & 6.67 & 15.00 & 15.00 & 3.46 & 8.24 & 3.73 & 10.00 & 10.59 & 72.69 \\
\hline 16 & S-19 & $10,17,22,14,21$ & 5.50 & 15.00 & 10.09 & 5.04 & 10.10 & 7.45 & 10.00 & 9.41 & 72.59 \\
\hline 17 & S-158 & $10,22,69,16,1$ & 6.67 & 15.00 & 15.00 & 3.16 & 8.24 & 3.73 & 10.00 & 10.59 & 72.39 \\
\hline 18 & S-27 & $10,17,22,14,69$ & 5.50 & 15.00 & 10.09 & 4.64 & 10.10 & 7.45 & 10.00 & 9.41 & 72.19 \\
\hline
\end{tabular}




\subsubsection{Intermediate List Ideas Not Appearing in Top Eighteen Strategies}

Table 9-4 lists the Intermediate List ideas that did not appear in the top eighteen Strategies and the SM Team judgment on why they were not components of the top Strategies.

Table 9-4: Intermediate Ideas Eliminated from 179 Strategies During First Down-select

\begin{tabular}{|l|l|l|}
\hline $\begin{array}{l}\text { IL } \\
\text { No. }\end{array}$ & Title of Idea & \multicolumn{1}{|c|}{$\begin{array}{c}\text { Probable Basis For Not Making } \\
\text { Top Eighteen }\end{array}$} \\
\hline IL-3 & $\begin{array}{l}\text { Use Tanks 4 through 8 for HLW Concentrate } \\
\text { Storage. }\end{array}$ & $\begin{array}{l}\text { Requires reuse of older tanks and delays } \\
\text { tank closure, which is contrary to major Site } \\
\text { mission goals. }\end{array}$ \\
\hline IL-4 & Use Tanks 4 through 8 for Emergency Space. & $\begin{array}{l}\text { Requires reuse of older tanks and delays } \\
\text { tank closure, which is contrary to major Site } \\
\text { mission goals. }\end{array}$ \\
\hline IL-5 & DWPF shutdown, FY-01 to FY-09 & $\begin{array}{l}\text { Impacts a major Site mission goal to } \\
\text { vitrify HLW (200 canisters per year) } \\
\text { and requires FFA to be renegotiated. }\end{array}$ \\
\hline IL-6 & $\begin{array}{l}\text { Process salt cake with low Cs-137 } \\
\text { into Class B Saltstone. }\end{array}$ & $\begin{array}{l}\text { May not comply with DOE Order } \\
\text { 435.1*; complexity of operation; } \\
\text { uncertainty on permits and how to } \\
\text { handle MST slurry from treatment; } \\
\text { requires use of available tank space } \\
\text { to process waste for disposal. }\end{array}$ \\
\hline IL-7 & $\begin{array}{l}\text { Process salt cake with low Cs-137 } \\
\text { into Class C Saltstone. }\end{array}$ & $\begin{array}{l}\text { May not comply with DOE Order } \\
\text { 435.1*; complexity of operation; } \\
\text { uncertainty on permits and how to } \\
\text { handle MST slurry from treatment; } \\
\text { requires use of available tank space } \\
\text { to process waste for disposal. }\end{array}$ \\
\hline IL-12 & $\begin{array}{l}\text { Treat DWPF Recycle at Late Wash } \\
\text { using Ion Exchange, sent to ETF. }\end{array}$ & $\begin{array}{l}\text { Complexity of operations based on } \\
\text { ion exchange; handling of spent } \\
\text { resin. }\end{array}$ \\
\hline IL-15 & $\begin{array}{l}\text { Treat DWPF Recycle in a Waste } \\
\text { Tank and Portable Unit to meet WAC } \\
\text { for Z Area. }\end{array}$ & $\begin{array}{l}\text { Complexity of op operation; } \\
\text { uncertainty on how to handle MST; } \\
\text { reuses Type IV tanks that are now } \\
\text { used to handle DWPF recycle } \\
\text { receipts. }\end{array}$ \\
\hline IL-24 & $\begin{array}{l}\text { Reduce DWPF production to 125 } \\
\text { cans per year. }\end{array}$ & $\begin{array}{l}\text { Impacts a major site mission goal to } \\
\text { average 200 canisters per year } \\
\text { production; requires FFA to be } \\
\text { renegotiated. }\end{array}$ \\
\hline
\end{tabular}


* DOE Order 435.1 specifies waste planned for disposal as $L L W$ is to be treated to reduce the concentration of radioactive contaminants to "As Low As Reasonably Achievable (ALARA)" using technically and economically feasible processes. Because demonstrated technology for Cs-137 removal is available, direct disposal of salt solution as a grout without treatment to remove Cs-137 may be in violation of this DOE Order.

\subsubsection{Effect of Ideas on Strategy Scores}

Figure 9-3 shows the average Strategy scores of all Strategies containing a particular idea. Mutually exclusive ideas are grouped together to show which ideas score highest in these groups. This metric indicates how a particular idea interacts with Strategies. Ideas that tend to pull Strategy scores up will have a higher average score, whereas ideas that tend to pull Strategy scores down will have lower average scores. Note that the eight ideas in Table 9-4 all rank low in this comparison, which further supports their absence from the top 18 Strategies.

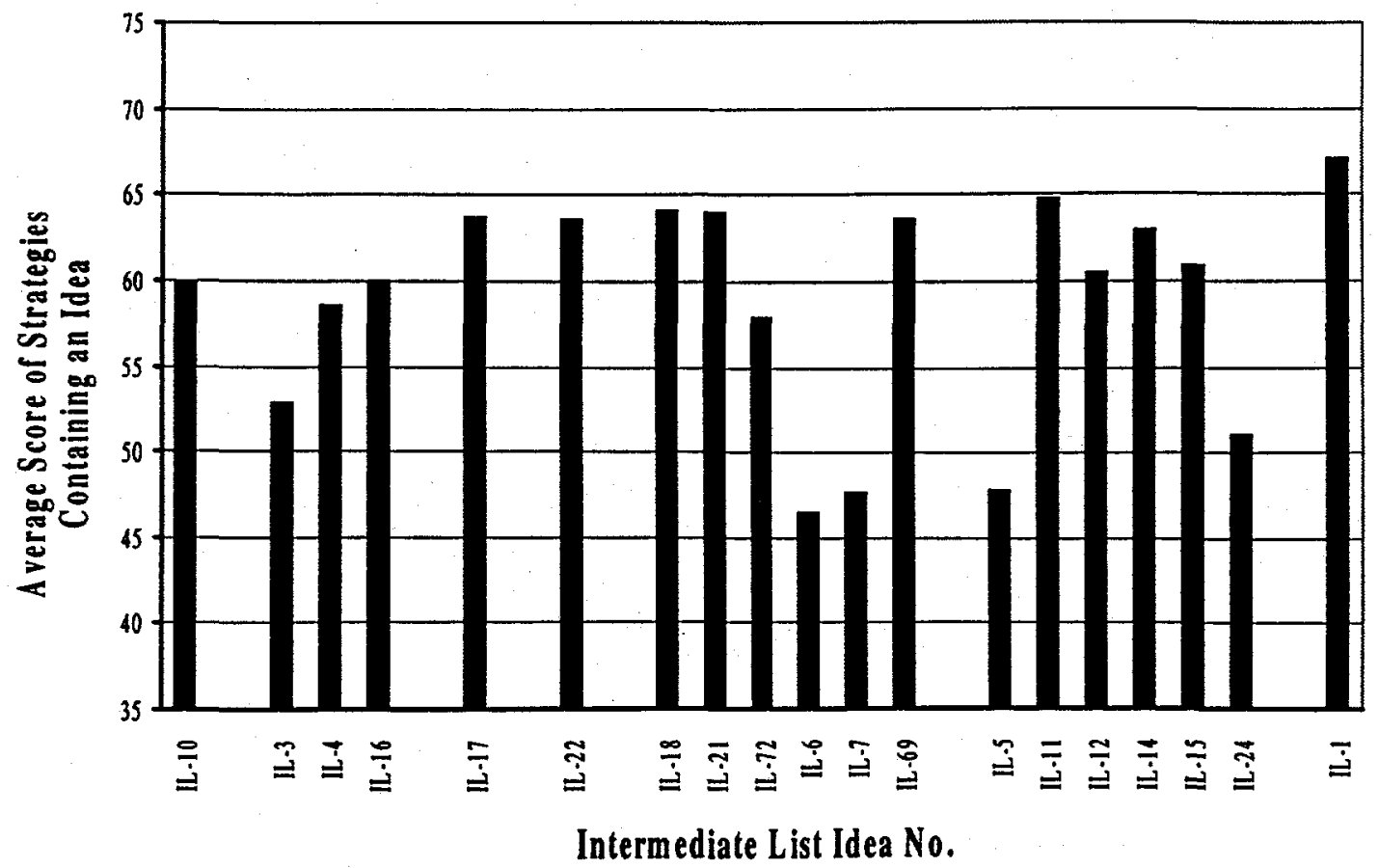

Figure 9-3: Effect of Ideas on Strategy Scores 


\subsection{Selection of Top Four Strategies}

The down-selection process used to reduce the number of Strategies from eighteen to the Short List of four Strategies is described in this section.

The eighteen Strategies (Table 9-3) have both common and unique combinations of ideas. Intermediate List idea IL-10 (Evaporate Backlog Waste) appears in each of the eighteen Strategies and is not useful as a discriminator for further downselection.

The SM Team further recognized that several subsets of the eighteen Strategies had very similar idea combinations. The only differences within these subsets were functionally equivalent ideas addressing specific aspects of a Strategy, i.e., handling of DWPF recycle, handling of ETF bottoms and addressing the issue of Emergency Space.

\subsubsection{Assessment of Strengths and Weakness of Strategies}

A subset of Strategies was assigned to a SM Team member to act as a sponsor. The SM Team member prepared detailed strengths and weaknesses of each Strategy within an assigned subset. The sponsor also recommended the preferred Strategy within the assigned subset.

After completing the individual sponsor reviews, a unified set of strengths and weaknesses for each Strategy was constructed and the SM Team collectively reviewed and discussed the strengths, weaknesses and subset recommendations for consensus. The strengths and weaknesses identified for each of the eighteen Strategies are discussed below in their rank order from Table 9-3. 
Consists of ideas:

Strategy S-101 -- Rank Value 1

10 Evaporate Backlog Waste

17 Reduce Emergency Space to $1300 \mathrm{k}$ Gallons

22 Allow TPB in Tank 49 to Decompose (HIW to Tank 49)

1 Build New HLW Tanks

\begin{tabular}{|c|c|}
\hline Advantages & $\begin{array}{r}\text { Disadvantages } \\
\end{array}$ \\
\hline $\begin{array}{l}\text { Low implementation cost in early years. } \\
\text { - Average excess space is high. } \\
\text { Retires the most Tanks (17). Provides option to } \\
\text { accelerate tank closures, if funded (4 more tanks } \\
\text { available than HLWSP Rev. } 10 \text { Planning Case). } \\
\text { Does not reuse Type I tanks, so they are } \\
\text { available for closure after emptying. } \\
\text { After processing Tank } 50 \text { material in FY04, Z } \\
\text { Area is not required to operate until FY09 when } \\
\text { Tank } 50 \text { is again full of ETF bottoms. }\end{array}$ & $\begin{array}{l}\text { Overall implementation cost is high. } \\
\text { Higher risk associated with building } 4 \text { HLW } \\
\text { tanks by } 2007 \text { due to regulatory or intervenor } \\
\text { delays. } \\
\text { Reduces Emergency Space in early years to } \\
\text { meet space need. Increases operational } \\
\text { complexity in dealing with emergency space. } \\
\text { Constructs } 4 \text { HLW tanks that must be closed. } \\
\text { Tank } 49 \text { space may not be gained when needed } \\
\text { if material does not decompose as expected. } \\
\text { Vulnerable to a "space shortfall" in the event of } \\
\text { a tank leak until new tanks are available (2007). }\end{array}$ \\
\hline
\end{tabular}

Consists of ideas:

Strategy S-104 -- Rank Value 2

10 Evaporate Backlog Waste

17 Reduce Emergency Space to $1300 \mathrm{~K}-\mathrm{Gal}$

18 ETF Bottoms to Z Area (HLW to Tank 50)

1 Build New HLW Tanks

\begin{tabular}{|l|l|}
\hline \multicolumn{1}{|c|}{ Advantages } \\
\hline $\begin{array}{l}\text { Retires the most Tanks (17). Provides option to } \\
\text { accelerate tank closures, if funded (4 more tanks } \\
\text { available than HLWSP Rev. 10 Planning Case). } \\
\text { Does not reuse Type I tanks, so they are }\end{array}$ \\
$\begin{array}{l}\text { available for closure after emptying. } \\
\text { Most TIAS for post } 2009 \text { needs. }\end{array}$ & $\begin{array}{c}\text { Overall implementation cost is high } \\
\text { Higher risk of regulatory or intervenor delays } \\
\text { associated with building } 4 \mathrm{HLW} \text { tanks by } 2007 .\end{array}$ \\
Low number of risks & $\begin{array}{c}\text { Constructs } 4 \mathrm{HLW} \text { tanks that must be closed. } \\
\text { Requires continuous staffing of Z Area starting } \\
\text { in FY05 to handle ETF bottoms. }\end{array}$ \\
$\begin{array}{l}\text { Interfaces broken between the ETF and the } \\
\text { Tank Farm and between Z Area and the Tank } \\
\text { Farm, eliminating interaction with the Tank Farm } \\
\text { to operate the ETF evaporator or Z Area. }\end{array}$ & $\begin{array}{c}\text { Reduces Emergency Space in early years to } \\
\text { meet space needs. Increases operational } \\
\text { complexity in dealing with emergency space. } \\
\text { Vulnerable to a "space shortfall" in the event of } \\
\text { a tank leak until new tanks are available (2007). }\end{array}$ \\
\hline
\end{tabular}




\section{Strategy S-105 -- Rank Value 3}

Consists of ideas:

10 Evaporate Backlog Waste

17 Reduce Emergency Space to 1300 K-Gal

21 New Tank for ETF Bottoms (HLW to Tank 50)

1 Build New HLW Tanks

\begin{tabular}{|c|c|}
\hline Advantages & Disadvantages \\
\hline $\begin{array}{l}\text { Provides } 6500 \mathrm{~K} \text {-gal of new HLW storage } \\
\text { space from } 4 \text { new tanks and reclaims Tank } 50 . \\
\text { Interfaces broken between the ETF and the } \\
\text { Tank Farm and between Z Area and the Tank } \\
\text { Farm, eliminating interaction with the Tank Farm } \\
\text { to operate the ETF evaporator or Z Area. } \\
\text { Provides about } 1000 \mathrm{~K} \text {-gal "cushion" for } \\
\text { continued operation beyond 2009, if needed. } \\
\text { Retires the most Tanks (17). Provides option to } \\
\text { accelerate tank closures, if funded (4 more tanks } \\
\text { available than HLWSP Rev. } 10 \text { Planning Case). } \\
\text { Does not reuse Type I tanks, so they are } \\
\text { available for closure after emptying. } \\
\text { Tank } 49 \text { is still available (in reserve) if needed, } \\
\text { due to changing missions or delays in other } \\
\text { projects ("new tanks for this Strategy" or "salt } \\
\text { treatment" facility). } \\
\text { Allows for efficient use of Solid Waste } \\
\text { resources. }\end{array}$ & $\begin{array}{l}\text { Reduces Emergency Space in early years to } \\
\text { meet space need. Increases operational } \\
\text { complexity in dealing with emergency space. } \\
\text { Vulnerable to a "space shortfall" in the event of } \\
\text { a tank leak until the new tanks are on-line (2007). } \\
\text { Requires intermittent operation of Z Area, but } \\
\text { with more efficient use of Solid Waste resources. } \\
\text { Two projects must be funded early - New tanks } \\
\text { for HLW, a new tank for ETF bottoms. } \\
\text { Overall implementation cost is high. } \\
\text { Higher risk of regulatory or intervenor delays } \\
\text { associated with building } 4 \text { HLW tanks by 2007. } \\
\text { - Constructs } 4 \text { HLW tanks that must be closed. } \\
\text { Vulnerable to a "space shortfall" in the event of } \\
\text { a tank leak until new tanks are available (2007). }\end{array}$ \\
\hline
\end{tabular}

Consists of ideas:

\section{Strategy S-107 - Rank Value 4}

10 Evaporate Backlog Waste

17 Reduce Emergency Space to $1300 \mathrm{~K}-\mathrm{Gal}$

69 Use Tanks in Reactor Areas for ETF Bottoms (HLW to Tank 50)

1 Build New HLW Tanks

\begin{tabular}{|c|c|}
\hline Advantages & Disadvantages \\
\hline $\begin{array}{l}\text { Interfaces broken between the ETF and the } \\
\text { Tank Farm and between Z Area and the Tank } \\
\text { Farm, eliminating interaction with the Tank Farm } \\
\text { to operate the ETF evaporator or Z Area. } \\
\text { After processing Tank } 50 \text { material in FY04, Z } \\
\text { Area not required to operate until FY09 when Salt } \\
\text { Processing starts. } \\
\text { Retires the most Tanks (17). Provides option to } \\
\text { accelerate tank closures, if funded (4 more tanks } \\
\text { available than HLWSP Rev. } 10 \text { Planning Case). } \\
\text { Does not reuse Type I tanks, so they are } \\
\text { available for closure after emptying. } \\
\text { Tank } 49 \text { remains in reserve if needed for } \\
\text { changing missions or delays in projects ("new } \\
\text { tanks for this Strategy" or "salt treatment" } \\
\text { facility). } \\
\text { Allows for efficient use of Solid Waste } \\
\text { resources. }\end{array}$ & $\begin{array}{l}\text { Overall implementation cost is high } \\
\text { Higher risk of regulatory or intervenor delays } \\
\text { associated with building } 4 \mathrm{HLW} \text { tanks by } 2007 \text {. } \\
\text { Constructs } 4 \mathrm{HLW} \text { tanks that must be closed. } \\
\text { Barely meets space need until new tanks are } \\
\text { operational. } \\
\text { Moving } 500,000 \text {-gal tanks from Reactor Areas } \\
\text { to store ETF Bottoms poses higher risk because } \\
\text { tanks may not be structurally sound after move. } \\
\text { Alternatively, RCRA permits and a transport } \\
\text { vehicle would be needed to move waste to the } \\
\text { tanks if they stay in Reactor areas. } \\
\text { Vulnerable to a "space shortfall" in the event of } \\
\text { a tank leak until new tanks are available (2007). }\end{array}$ \\
\hline
\end{tabular}


Consists of ideas:

Strategy S-13 - Rank Value 5

10 Evaporate Backlog Waste

17 Reduce Emergency Space to $1300 \mathrm{~K}-\mathrm{Gal}$

22 Allow TPB in Tank 49 to Decompose (HLW to Tank 49)

11 Evaporator in DWPF Salt Cell for DWPF Recycle

18 ETF Bottoms to Z Area (HLW to Tank 50)

\begin{tabular}{|l|l|}
\hline \multicolumn{1}{|c|}{ Advantages } & \multicolumn{1}{c|}{ Disadvantages } \\
\hline Does not impact tank closures (13) in HLWSP & Installs an evaporator in the DWPF Salt Cell; \\
Rev. 10 Planning Case, if funded. & acid hydrolysis process must either be done \\
- Interface broken between DWPF and Tank & elsewhere, if needed as part of future operations \\
Farm for DWPF recycle. Outage planning is & (depends on Alt. Salt process chosen) or \\
simplified. & reinstalled in 2009, eliminating evaporator for \\
- Intermediate number of risks. & DWPF recycle. \\
- Lower overall cost. & Requires continuous staffing of Z Area starting \\
- Does not reuse Type I tanks, so they are & in FY05 to handle small ETF concentrate stream \\
available for closure after emptying. & Reduces Emergency Space in early years to \\
Interfaces broken between the ETF and the & meet space needs. Increases operational \\
Tank Farm and between Z Area and the Tank & complexity in dealing with emergency space. \\
Farm, eliminating interaction with the Tank Farm & Tank 49 space may not be gained when needed \\
to operate the ETF evaporator or Z Area. & if material does not decompose as expected. \\
\hline
\end{tabular}

Consists of ideas:

\section{Strategy S-59 - Rank Value 6}

10 Evaporate Backlog Waste

17 Reduce Emergency Space to $1300 \mathrm{k}$ Gallons

22 Allow TPB in Tank 49 to Decompose (HLW to Tank 49)

16 Small Tanks for Emergency Space

18 ETF Bottoms to $Z$ Area (HLW to Tank 50)

\begin{tabular}{|c|c|}
\hline Advantages & Disadvantages \\
\hline $\begin{array}{l}\text { Average excess space is good } \\
\text { Does not impact tank closures (13) in HLWSP } \\
\text { Rev. } 10 \text { Planning Case, if funded. } \\
\text { Does not reuse Type I tanks, so they are } \\
\text { available for closure after emptying. } \\
\text { Interfaces broken between the ETF and the } \\
\text { Tank Farm and between } Z \text { Area and the Tank } \\
\text { Farm, eliminating interaction with the Tank Farm } \\
\text { to operate the ETF evaporator or Z Area. }\end{array}$ & $\begin{array}{l}\text { Overall implementation cost is high. } \\
\text { - Reduces Emergency Space early to meet space } \\
\text { needs; increases operational complexity in dealing } \\
\text { with emergency space. } \\
\text { Requires continuous staffing of Z Area starting } \\
\text { in FY05 to handle ETF bottoms stream. } \\
\text { Although used for emergency space, higher risk } \\
\text { of regulatory or intervenor delay is associated } \\
\text { with building } 42 \text { small tanks by } 2007 \text {. } \\
\quad \text { Operational complexity to survey and maintain } \\
42 \text { tanks (likely located away from Tank Farm). } \\
\text { Constructs } 42 \text { HLW tanks that must be closed. } \\
\text { Tank } 49 \text { space may not be gained when needed } \\
\text { if material does not decompose as expected. }\end{array}$ \\
\hline
\end{tabular}




\section{Consists of ideas:}

\section{Strategy S-17 -. Rank Value 7}

10 Evaporate Backlog Waste

17 Reduce Emergency Space to $1300 \mathrm{~K}-\mathrm{Gal}$

22 Allow TPB in Tank 49 to Decompose (HLW to Tank 49)

11 Evaporator in DWPF Salt Cell for DWPF Recycle

21 New Tank for ETF Bottoms (HLW to Tank 50)

\begin{tabular}{|c|c|}
\hline Advantages & Disadvantages \\
\hline $\begin{array}{l}\text { Does not impact tank closures (13) in HLWSP } \\
\text { Rev. } 10 \text { Planning Case, if funded. } \\
\text { Interface broken between DWPF and Tank } \\
\text { Farm for DWPF recycle. Outage planning is } \\
\text { simplified. } \\
\text { Intermediate number of risks } \\
\text { Does not reuse Type I tanks, so they are } \\
\text { available for closure after emptying. } \\
\text { Provides excess space above ASB, especially in } \\
\text { the early years (through 2007), which reduces the } \\
\text { risk of delays in feed preparation for DWPF (ESP } \\
\text { processing). } \\
\text { Interfaces broken between the ETF and the } \\
\text { Tank Farm and between Z Area and the Tank } \\
\text { Farm, eliminating interaction with the Tank Farm } \\
\text { to operate the ETF evaporator or Z Area. } \\
\text { Allows for efficient use of Solid Waste } \\
\text { resources. }\end{array}$ & $\begin{array}{l}\text { - Intermediate Costs } \\
\text { Reduces Emergency Space in early years to } \\
\text { meet space needs. Increases operational } \\
\text { complexity in dealing with emergency space. } \\
\text { - Requires intermittent operation of Z Area, but } \\
\text { with more efficient use of Solid Waste resources. } \\
\text { Installs an evaporator in the DWPF Salt Cell; } \\
\text { acid hydrolysis process must either be done } \\
\text { elsewhere, if needed as part of future operations } \\
\text { (depends on Alt. Salt process chosen) or } \\
\text { reinstalled in } 2009 \text {, eliminating evaporator for } \\
\text { DWPF recycle. } \\
\text { Tank } 49 \text { space may not be gained when needed } \\
\text { if material does not decompose as expected. }\end{array}$ \\
\hline
\end{tabular}

Consists of ideas:

\section{Strategy S-25 -- Rank Value 8}

10 Evaporate Backlog Waste

17 Reduce Emergency Space to $1300 \mathrm{~K}-\mathrm{Gal}$

22 Allow TPB in Tank 49 to Decompose (HLW to Tank 49)

11 Evaporator in DWPF Salt Cell for DWPF Recycle

69 Use Tanks in Reactor Areas for ETF Bottoms (HLW to Tank 50)

\begin{tabular}{|c|c|}
\hline Advantages & Disadvantages \\
\hline $\begin{array}{l}\text { Provides } 2200 \mathrm{~K} \text {-gal of new HLW storage } \\
\text { space from Tank } 49 \text { and Tank } 50 \text {. } \\
\text { Interfaces broken between the ETF and the } \\
\text { Tank Farm and between Z Area and the Tank } \\
\text { Farm, eliminating interaction with the Tank Farm } \\
\text { to operate the ETF evaporator or Z Area. } \\
\text { After processing Tank } 50 \text { material in FY04, Z } \\
\text { Area not required to operate until FY09 when Salt } \\
\text { Processing starts. } \\
\text { Provides excess space above ASB, especially in } \\
\text { the early years (through 2007), which reduces the } \\
\text { risk of delays in feed preparation for DWPF (ESP } \\
\text { processing). } \\
\text { Does not impact tank closures (13) in HLWSP } \\
\text { Rev. } 10 \text { Planning Case, if funded. } \\
\text { Does not reuse Type I tanks, so they are }\end{array}$ & $\begin{array}{l}\text { Reduces Emergency Space in early years to } \\
\text { meet space needs. Increases operational } \\
\text { complexity in dealing with emergency space. } \\
\text { Installs an evaporator in the DWPF Salt Cell; } \\
\text { acid hydrolysis process must either be done } \\
\text { elsewhere, if needed as part of future operations } \\
\text { (depends on Alt. Salt process chosen) or } \\
\text { reinstalled in 2009, eliminating evaporator for } \\
\text { DWPF recycle. } \\
\text { Moving 500,000-gal tanks from Reactor Areas } \\
\text { to store ETF Bottoms poses higher risk because } \\
\text { tanks may not be structurally sound after move. } \\
\text { Alternatively, RCRA permits and a transport } \\
\text { vehicle would be needed to move waste to the } \\
\text { tanks if they stay in Reactor areas. } \\
\text { Minimal excess space above ASB beyond }\end{array}$ \\
\hline
\end{tabular}


available for closure after emptying.

- Several minor projects to achieve, but no major project such as building new waste tanks needed.

- Interface broken between DWPF and Tank Farm for DWPF recycle. Outage planning is simplified.

- Allows for efficient use of Solid Waste resources.
2009; if salt cell evaporator is replaced for acid hydrolysis equipment then space is further reduced $(-200 \mathrm{~K}-\mathrm{gal} / \mathrm{yr})$.

- Tank 49 space may not be gained when needed if material does not decompose as expected.

Consists of ideas:

Strategy S-15 _- Rank Value 9

10 Evaporate Backlog Waste

17 Reduce Emergency Space to $1300 \mathrm{~K}-\mathrm{Gal}$

22 Allow TPB in Tank 49 to Decompose (HIW to Tank 49)

14 Evaporator in LWF for DWPF Recycle

18 ETF Bottoms to Z Area (HLW to Tank 50)

\begin{tabular}{|c|c|}
\hline Advantages & Disadvantages \\
\hline Exceeds ASB through 2005 without LWF & Early years cost requirements for LW \\
Evaporator; a one-year delay can be tolerated. & Evaporator Project \\
- Does not impact tank closures (13) in HLWSP & Requires continuous staffing of Z Area starting \\
Rev. 10 Planning Case, if funded. & in FY05 to handle small ETF concentrate stream \\
Does not reuse Type I tanks, so they are & Prevents use of LWF for pilot scale facility for \\
available for closure after emptying. & alternative salt process. \\
Interfaces broken between the ETF and the & Tank 49 space may not be gained when needed \\
Tank Farm and between Z Area and the Tank & if material does not decompose as expected. \\
Farm, eliminating interaction with the Tank Farm & \\
to operate the ETF evaporator or Z Area. & \\
\hline
\end{tabular}

Consists of ideas:

\section{Strategy S-60 -- Rank Value 10}

10 Evaporate Backlog Waste

17 Reduce Emergency Space to $1300 \mathrm{k}$ gallons

22 Allow TPB in Tank 49 to Decompose (HLW to Tank 49)

16 Small Tanks for Emergency Space

21 New Tank for ETF Bottoms (HLW to Tank 50)

\begin{tabular}{|c|c|}
\hline Advantages & Disadvantages \\
\hline $\begin{array}{l}\text { Average excess space is good } \\
\text { Allows for efficient use of Solid Waste } \\
\text { resources. } \\
\text { Does not impact tank closures (13) in HLWSP } \\
\text { Rev. } 10 \text { Planning Case, if funded. } \\
\text { Does not reuse Type I tanks, so they are } \\
\text { available for closure after emptying. } \\
\text { Interfaces broken between the ETF and the } \\
\text { Tank Farm and between Z Area and the Tank } \\
\text { Farm, eliminating interaction with the Tank Farm } \\
\text { to operate the ETF evaporator or } Z \text { Area. }\end{array}$ & $\begin{array}{l}\text { Overall implementation cost is high } \\
\text { Reduces Emergency Space in early years to } \\
\text { meet space needs. Increases operational } \\
\text { complexity in dealing with emergency space. } \\
\text { Although used for emergency space, higher risk } \\
\text { of regulatory or intervenor delays is associated } \\
\text { with building } 42 \text { small tanks by } 2007 \text {. } \\
\text { Operational complexity to survey and maintain } \\
42 \text { tanks (likely located away from Tank Farm). } \\
\text { Tank } 49 \text { space may not be gained when needed } \\
\text { if material does not decompose as expected. } \\
\text { Requires intermittent operation of } Z \text { Area, but } \\
\text { with more efficient use of Solid Waste resources. }\end{array}$ \\
\hline
\end{tabular}


Consists of ideas:

\section{Strategy S-143 -- Rank Value 11}

10 Evaporate Backlog Waste

22 Allow TPB in Tank 49 to Decompose (HLE to Tank 49)

21 New Tank for ETF Bottoms (HLW to Tank 50)

11 Evaporator in DWPF Salt Cell for DWPF Recycle

1 Build New HLW Tanks

\begin{tabular}{|c|c|}
\hline Advantages & Disadvantages \\
\hline $\begin{array}{l}\text { Interface broken between DWPF and Tank } \\
\text { Farm for DWPF recycle. Outage planning is } \\
\text { simplified. } \\
\text { Retires the most Tanks (17). Provides option to } \\
\text { accelerate tank closures, if funded (4 more tanks } \\
\text { available than HLWSP Rev. 10 Planning Case). } \\
\text { Does not reuse Type I tanks, so they are } \\
\text { available for closure after emptying. } \\
\text { Interfaces broken between the ETF and the } \\
\text { Tank Farm and between Z Area and the Tank } \\
\text { Farm, eliminating interaction with the Tank Farm } \\
\text { to operate the ETF evaporator or Z Area. } \\
\text { Does not reduce Emergency Space. } \\
\text { Allows for efficient use of Solid Waste } \\
\text { resources. }\end{array}$ & $\begin{array}{l}\text { Overall implementation cost high } \\
\text { - Average excess not as high as other Strategies } \\
\text { (especially in early years) } \\
\text { Installs an evaporator in the DWPF Salt Cell; } \\
\text { acid hydrolysis process must either be done } \\
\text { elsewhere, if needed as part of future operations } \\
\text { (depends on Alt. Salt process chosen) or } \\
\text { reinstalled in } 2009 \text {, eliminating evaporator for } \\
\text { DWPF recycle. } \\
\text { - Higher risk of regulatory or intervenor delays } \\
\text { associated with building } 4 \text { HLW tanks by } 2007 . \\
\text { Constructs } 4 \text { HLW tanks that must be closed. } \\
\text { Tank } 49 \text { space may not be gained when needed } \\
\text { if material does not decompose as expected. } \\
\text { - Requires intermittent operation of Z Area, but } \\
\text { with more efficient use of Solid Waste resources. } \\
\text { Vulnerable to a "space shortfall" in the event of } \\
\text { a tank leak until the new tanks are available } \\
\text { (2007). }\end{array}$ \\
\hline
\end{tabular}

Consists of ideas:

Strategy S-62 - Rank Value 12

10 Evaporate Backlog Waste

17 Reduce Emergency Space to $1300 \mathrm{~K}-\mathrm{Gal}$

22 Allow TPB in Tank 49 to Decompose (HLW to Tank 49)

16 Small Tanks for Emergency Space

69 Use Tanks in Reactor Areas for ETF Bottoms (HLW to Tank 50)

\begin{tabular}{|c|c|}
\hline Advantages & Disadvantages \\
\hline $\begin{array}{l}\text { Does not impact tank closures (13) in HLWSP } \\
\text { Rev. } 10 \text { Planning Case, if funded. } \\
\text { Intermediate number of risks } \\
\text { Does not reuse Type I tanks, so they are } \\
\text { available for closure after emptying. } \\
\text { Interfaces broken between the ETF and the } \\
\text { Tank Farm and between Z Area and the Tank } \\
\text { Farm, eliminating interaction with the Tank Farm } \\
\text { to operate the ETF evaporator or Z Area. } \\
\text { After processing Tank } 50 \text { material in FY04, Z } \\
\text { Area not required to operate until FY09 when Salt } \\
\text { Processing starts. } \\
\text { Allows for efficient use of Solid Waste } \\
\text { resources. }\end{array}$ & $\begin{array}{l}\text { Cost }=\$ 100 \mathrm{M} \text { in } 2003 ; \text { LCC of } \$ 553 \mathrm{M} \\
\text { - Although used for emergency space, higher risk } \\
\text { of regulatory or intervenor delays is associated } \\
\text { with building } 42 \text { small tanks by } 2007 \text {. } \\
\text { - Constructs } 42 \mathrm{HLW} \text { tanks that must be closed. } \\
\text { Reduces Emergency Space in early years to } \\
\text { meet space needs. Increased operational } \\
\text { complexity in dealing with emergency space. } \\
\text { Moving } 500,000 \text {-gal tanks from Reactor Areas } \\
\text { to store ETF Bottoms poses higher risk because } \\
\text { tanks may not be structurally sound after move. } \\
\text { Alternatively, RCRA permits and a transport } \\
\text { vehicle would be needed to move waste to the } \\
\text { tanks if they stay in Reactor areas. } \\
\text { Tank } 49 \text { space may not be gained when needed } \\
\text { if material does not decompose as expected. }\end{array}$ \\
\hline
\end{tabular}


Consists of ideas:

\section{Strategy S-151 -- Rank Value 13}

10 Evaporate Backlog Waste

22 Allow TPB in Tank 49 to Decompose (HLW to Tank 49)

69 Use Tanks in Reactor Areas for ETF Bottoms (HLW to Tank 50)

11 Evaporator in DWPF Salt Cell for DWPF Recycle

1 Build New HLW Tanks

\begin{tabular}{|c|c|}
\hline Advantages & Disadvantages \\
\hline $\begin{array}{l}\text { Does not reduce Emergency Space. } \\
\text { Provides } 6500 \mathrm{~K} \text {-gal of new HLW storage } \\
\text { space from } 4 \text { new tanks and reclaiming Tank } 50 \text {. } \\
\text { Interfaces broken between ETF and the Tank } \\
\text { Farm and between } Z \text { Area and the Tank Farm, } \\
\text { eliminating interaction with the Tank Farm to } \\
\text { operate the ETF evaporator or Z Area. } \\
\text { After processing Tank } 50 \text { material in FY04, Z } \\
\text { Area not required to operate until FY09 when Salt } \\
\text { Processing starts. } \\
\text { Provides about } 1000 \mathrm{~K} \text {-gal "cushion" for } \\
\text { continued operation beyond } 2009 \text {, if needed. } \\
\text { Retires the most Tanks (17). Provides option to } \\
\text { accelerate tank closures, if funded (4 more tanks } \\
\text { available than HLWSP Rev. } 10 \text { Planning Case). } \\
\text { - Does not reuse Type I tanks, so they are } \\
\text { available for closure after emptying. } \\
\text { Interface broken between DWPF and Tank } \\
\text { Farm for DWPF recycle. Outage planning is } \\
\text { simplified. } \\
\text { Allows for efficient use of Solid Waste } \\
\text { resources. }\end{array}$ & $\begin{array}{l}\text { Three projects must be funded early - New } \\
\text { tanks for HLW; move reactor tanks; salt cell } \\
\text { evaporator. } \\
\text { - Installs an evaporator in the DWPF Salt Cell; } \\
\text { acid hydrolysis process must either be done } \\
\text { elsewhere, if needed as part of future operations } \\
\text { (depends on Alt. Salt process chosen) or } \\
\text { reinstalled in 2009, eliminating evaporator for } \\
\text { DWPF recycle. } \\
\text { Moving 500,000-gal tanks from Reactor Areas } \\
\text { to store ETF Bottoms poses higher risk because } \\
\text { tanks may not be structurally sound after move. } \\
\text { Alternatively, RCRA permits and a transport } \\
\text { vehicle would be needed to move waste to the } \\
\text { tanks if they stay in Reactor areas. } \\
\text { Overall implementation cost is high. } \\
\text { - Higher risk of regulatory or intervenor delays } \\
\text { associated with building } 4 \text { HLW tanks by } 2007 \text {. } \\
\text { Four additional HLW tanks to close. } \\
\text { Tank } 49 \text { space may not be gained when needed } \\
\text { if material does not decompose as expected. }\end{array}$ \\
\hline
\end{tabular}

Consists of ideas:

Strategy S-106 -- Rank Value 14

10 Evaporate Backlog Waste

17 Reduce Emergency Space to $1300 \mathrm{~K}-\mathrm{Gal}$

72 Use Type IV tank for ETF Bottoms

1 Build New HLW Tanks

\begin{tabular}{|c|c|}
\hline Advantages & Disadvantages \\
\hline $\begin{array}{l}\text { Retires the most Tanks (17). Provides option to } \\
\text { accelerate tank closures, if funded (4 more tanks } \\
\text { available than HLWSP Rev. } 10 \text { Planning Case). } \\
\text { After processing Tank } 50 \text { material in FY04, Z } \\
\text { Area not required to operate until FY09 when Salt } \\
\text { Processing starts. } \\
\text { - Utilizes existing facilities. } \\
\text { Does not reuse Type I tanks, so they are } \\
\text { available for closure after emptying. } \\
\text { Tank } 49 \text { is still available (in reserve) if needed, } \\
\text { due to changing missions or delays in other } \\
\text { projects ("new tanks for this Strategy" or "salt } \\
\text { treatment" facility). }\end{array}$ & $\begin{array}{l}\text { Overall implementation cost is high } \\
\text { Higher risk of regulatory or intervenor delays } \\
\text { associated with building } 4 \text { HLW tanks by } 2007 \text {. } \\
\text { Constructs } 4 \text { HLW tanks that must be closed. } \\
\text { Vulnerable to a "space shortfall" in the event of } \\
\text { a tank leak until the new tanks are available } \\
\text { (2007). } \\
\text { Puts waste ready for final treatment and } \\
\text { disposal (ETF bottoms) into HLW tanks; waste } \\
\text { will require further treatment before disposal. } \\
\text { Would impact use of Type IV tanks for storage } \\
\text { of spent washes from ESP. }\end{array}$ \\
\hline
\end{tabular}


Consists of ideas:

\section{Strategy S-156 -- Rank Value 15}

10 Evaporate Backlog Waste

22 Allow TPB in Tank 49 to Decompose (HLW to Tank 49)

21 New Tank for ETF Bottoms (HLW to Tank 50)

16 Small Tanks for Emergency Space

1 Build New HLW Tanks

\begin{tabular}{|c|c|}
\hline Advantages & Disadvantages \\
\hline $\begin{array}{l}\text { Allows for efficient use of Solid Waste } \\
\text { resources. } \\
\text { Does not impact tank closures (13) in HLWSP } \\
\text { Rev. } 10 \text { Planning Case, if funded. } \\
\text { Does not reuse Type I tanks, so they are } \\
\text { available for closure after emptying. } \\
\text { Interfaces broken between the ETF and the } \\
\text { Tank Farm and between } Z \text { Area and the Tank } \\
\text { Farm, eliminating interaction with the Tank Farm } \\
\text { to operate the ETF evaporator or Z Area. } \\
\text { Does not reduce Emergency Space. }\end{array}$ & $\begin{array}{l}\text { Overall implementation cost very, very high } \\
\text { Higher risk of regulatory or intervenor delays } \\
\text { associated with building } 4 \text { HLW tanks by } 2007 \text {. } \\
\text { Although used for emergency space, higher risk } \\
\text { of regulatory or intervenor delays associated with } \\
\text { building } 42 \text { small tanks by } 2007 \text {. } \\
\text { Constructs } 46 \mathrm{HLW} \text { tanks that must be closed. } \\
\text { Operational complexity to survey and maintain } \\
46 \text { more tanks (likely located away from Tank } \\
\text { Farm). } \\
\text { Tank } 49 \text { space may not be gained when needed } \\
\text { if material does not decompose as expected. } \\
\text { Requires intermittent operation of Z Area, but } \\
\text { with more efficient use of Solid Waste resources. }\end{array}$ \\
\hline
\end{tabular}

Consists of ideas:

\section{Strategy S-19 -- Rank Value 16}

10 Evaporate Backlog Waste

17 Reduce Emergency Space to $1300 \mathrm{~K}-\mathrm{Gal}$

22 Allow TPB in Tank 49 to Decompose (HLW to Tank 49)

14 Evaporator in LWF for DWPF Recycle

21 New Tank for ETF Bottoms (HIW to Tank 50)

\begin{tabular}{|c|c|}
\hline Advantages & Disadvantages \\
\hline $\begin{array}{l}\text { Provides - } 2200 \mathrm{~K} \text {-gal of new HLW storage } \\
\text { space from Tank } 49 \text { and Tank } 50 \text {. } \\
\text { Interfaces broken between the ETF and the } \\
\text { Tank Farm and between Z Area and the Tank } \\
\text { Farm, eliminating interaction with the Tank Farm } \\
\text { to operate the ETF evaporator or Z Area. } \\
\text { Does not impact tank closures (13) in HIWSP } \\
\text { Rev. } 10 \text { Planning Case, if funded. } \\
\text { Does not reuse Type I tanks, so they are } \\
\text { available for closure after emptying. } \\
\text { Several minor projects needed, but no major } \\
\text { project such as building new waste tanks needed. } \\
\text { Provides excess space over the entire time } \\
\text { period, which would reduce the risk of delays in } \\
\text { feed preparation for DWPF (ESP processing). } \\
\text { Retains salt cell for its intended use. } \\
\text { Interface broken between DWPF and Tank } \\
\text { Farm for DWPF recycle. Outage planning is } \\
\text { simplified. } \\
\text { Allows for efficient use of Solid Waste } \\
\text { resources. }\end{array}$ & $\begin{array}{l}\text { Minimal space cushion beyond } 2009 \text {. } \\
\text { - Prevents use of LWF for pilot scale facility for } \\
\text { alternative salt process. } \\
\text { - } \text { Reduces Emergency Space in early years to } \\
\text { meet space needs. Increases operational } \\
\text { complexity in dealing with emergency space. } \\
\text { - Tank } 49 \text { space may not be gained when needed } \\
\text { if material does not decompose as expected. } \\
\text { - Requires intermittent operation of Z Area, but } \\
\text { with more efficient use of Solid Waste resources. }\end{array}$ \\
\hline
\end{tabular}


Consists of ideas:

\section{Strategy S-158 .. Rank Value 17}

10 Evaporate Backlog Waste

22 Allow TPB in Tank 49 to Decompose (HLW to Tank 49)

69 Use Tanks in Reactor Areas for ETF Bottoms (HLW to Tank 50)

16 Small Tanks for Emergency Space.

1 Build New HLW Tanks

\begin{tabular}{|c|c|}
\hline Advantages & Disadvantages \\
\hline $\begin{array}{l}\text { Allows for efficient use of Solid Waste } \\
\text { resources. } \\
\text { Does not impact tank closures (13) in HLWSP } \\
\text { Rev. } 10 \text { Planning Case, if funded. } \\
\text { Does not reuse Type I tanks, so they are } \\
\text { available for closure after emptying. } \\
\text { Interfaces broken between the ETF and the } \\
\text { Tank Farm and between Z Area and the Tank } \\
\text { Farm, eliminating interaction with the Tank Farm } \\
\text { to operate the ETF evaporator or Z Area. } \\
\text { After processing Tank } 50 \text { material in FY04, Z } \\
\text { Area not required to operate until FY09 when Salt } \\
\text { Processing starts. } \\
\text { Does not reduce Emergency Space. }\end{array}$ & $\begin{array}{l}\text { Overall implementation cost very, very high. } \\
\text { Higher risk of regulatory or intervenor delays } \\
\text { associated with building } 4 \mathrm{HLW} \text { tanks by } 2007 \text {. } \\
\text { Although used for emergency space, higher risk } \\
\text { of regulatory or intervenor delay is associated } \\
\text { with building } 42 \text { small tanks by } 2007 \text {. } \\
\text { Operationally complex to survey and maintain } \\
46 \text { more tanks (likely located away from Tank } \\
\text { Farm). } \\
\text { Constructs } 46 \mathrm{HLW} \text { tanks that must be closed. } \\
\text { Tank } 49 \text { space may not be gained when needed } \\
\text { if material does not decompose as expected. } \\
\text { After moving, the } 500,000 \text {-gal tanks from } \\
\text { Reactor Areas used to store ETF Bottoms pose } \\
\text { higher risk because tanks may not be structurally } \\
\text { sound after move. Alternatively, RCRA permits } \\
\text { and a transport vehicle would be needed to move } \\
\text { waste to the tanks if they stay in Reactor areas. }\end{array}$ \\
\hline
\end{tabular}

Consists of ideas:

Strategy S-27 - Rank Value 18

10 Evaporate Backlog Waste

17 Reduce Emergency Space to $1300 \mathrm{~K}$-Gal

22 Allow TPB in Tank 49 to Decompose (HLW to Tank 49)

14. Evaporator in LWF for DWPF Recycle

69 Use Tanks in Reactor Areas for ETF Bottoms (HLW to Tank 50)

\begin{tabular}{|c|c|}
\hline Advantages & Disadvantages \\
\hline $\begin{array}{l}\text { Does not impact tank closures (13) in HLWSP } \\
\text { Rev. } 10 \text { Planning Case, if funded. } \\
\text { Interface broken between DWPF and Tank } \\
\text { Farm for DWPF recycle. Outage planning is } \\
\text { simplified. } \\
\text { - Intermediate number of risks. } \\
\text { - Does not reduce Emergency Space. } \\
\text { Does not reuse Type I tanks after emptying, so } \\
\text { they are available for closure. } \\
\text { Interfaces broken between the ETF and the } \\
\text { Tank Farm and between Z Area and the Tank } \\
\text { Farm, eliminating interaction with the Tank Farm } \\
\text { to operate the ETF evaporator or Z Area. } \\
\text { After processing Tank 50 material in FY04, Z } \\
\text { Area not required to operate until FYO9 when Salt } \\
\text { Processing starts. } \\
\text { Allows for efficient use of Solid Waste } \\
\text { resources. }\end{array}$ & $\begin{array}{l}\text { - Intermediate Costs } \\
\text { Moving 500,000-gal tanks from Reactor Areas } \\
\text { to store ETF Bottoms poses higher risk because } \\
\text { tanks may not be structurally sound after move. } \\
\text { Alternatively, RCRA permits and a transport } \\
\text { vehicle would be needed to move waste to the } \\
\text { tanks if they stay in Reactor areas. } \\
\text { Prevents use of LWF for pilot scale facility for } \\
\text { Alternative Salt Process. } \\
\text { Reduces Emergency Space in early years to } \\
\text { meet space needs. Increases operational } \\
\text { complexity in dealing with emergency space. } \\
\text { Vulnerable to a "space shortfall" in the event of } \\
\text { a tank leak early in the period. } \\
\text { - Tank } 49 \text { space may not be gained when needed } \\
\text { if material does not decompose as expected. }\end{array}$ \\
\hline
\end{tabular}


The SM Team then used the above strength and weakness information, input from Stakeholders, expertise and judgement to select a preferred Intermediate List idea from a group of functionally equivalent ideas that appeared in the top 18 Strategies, as shown in Table 9-5.

Table 9-5: Comparison of Functionally Equivalent Ideas

\begin{tabular}{|l|l|}
\hline \multicolumn{1}{|c|}{ Waste Stream or Issue to Manage } & $\begin{array}{c}\text { Equivalent Intermediate List Ideas that } \\
\text { Manage a Waste Stream or Issue }\end{array}$ \\
\hline Handling of DWPF Recycle & $\mathrm{LL}-11, \mathrm{~L}-14$ \\
\hline Handling of ETF Bottoms & $\mathrm{IL}-21, \mathrm{IL}-18, \mathrm{~L}-69, \mathrm{IL}-72$ \\
\hline Handling of Emergency Space & $\mathrm{IL}-17, \mathrm{~L}-16$ \\
\hline
\end{tabular}

A comparison was then made between functionally equivalent Strategies to select those Strategies that contained only the favored ideas. Elimination of Strategies containing less favorable ideas $(14,16,18,69$ and 72$)$ reduced the number of Strategies from eighteen to four. Details of these down-selections are described below.

\subsubsection{Handling of DWPF Recycle}

Intermediate List idea $\mathrm{IL}-11$ was considered more favorable for handling the DWPF recycle stream than IL-14 because it consistently ranked higher when Strategies that differed only in these two ideas were compared. By installing an Evaporator for the DWPF recycle stream in the Salt Cell (IL-11), the interface between DWPF and the Tank Farm to handle the DWPF recycle stream is eliminated. However, a new interface would be created between DWPF and ETF by extending the existing line that now leads from the OWST to the CIF. This line would be extended to the H-Area Process Sewer line behind the H-Canyon Building; which presently connects to ETF. If an Evaporator were installed in the LWF instead of the Salt Cell, multiple waste transfers between the DWPF to the LWF would be required to evaporate the waste and the bottoms must then be returned to the DWPF canyon. The overheads would still be sent to the ETF, but the use of the LWF would require these transfers to be made via the Tank Farm.

Three pairs of Strategies from the top eighteen Strategies are shown in Table 9-6 that differ only in how the DWPF recycle stream is managed. 
Table 9-6: Down-Selection for Managing DWPF Recycle

\begin{tabular}{|l|c|c|c|}
\hline $\begin{array}{c}\text { Waste Stream or } \\
\text { Issue to Manage }\end{array}$ & $\begin{array}{c}\text { Strategy } \\
\text { Rank }\end{array}$ & $\begin{array}{c}\text { Strategy } \\
\text { No. }\end{array}$ & $\begin{array}{c}\text { Intermediate List } \\
\text { Ideas Used }\end{array}$ \\
\hline DWPF Recycle & 5 & S-13 & $10,17,22,11,18$ \\
\hline DWPF Recycle & 9 & S-15 & $10,17,22,14,18$ \\
\hline & & & \\
\hline DWPF Recycle & 7 & S-17 & $10,17,22,11,21$ \\
\hline DWPF Recycle & 16 & S-19 & $10,17,22,14,21$ \\
\hline & & & \\
\hline DWPF Recycle & 8 & S-25 & $10,17,22,11,69$ \\
\hline DWPF Recycle & 18 & S-27 & $10,17,22,14,69$ \\
\hline
\end{tabular}

In this down-selection, three Strategies (S-15, S-19 and S-27) that contained Intermediate List idea $\mathbb{L}-14$ were eliminated from the list of the top eighteen Strategies, reducing the list to fifteen.

\subsubsection{Handling of ETF Bottoms}

Intermediate List idea $\mathbb{L}-72$ consistently ranked lower than $\mathbb{L}-18, \mathbb{L}-21$ or $\mathbb{L}-69$ among the Strategies that differed only in the idea selected to handle ETF bottoms. IL-18, IL-21, and $\mathbb{L}-69$ were ranked very close, with $\mathbb{I L}-18$ being slightly better then the other two. Therefore, it is difficult to select an idea based on HLW needs only. However, discussions with Solid Waste Personnel revealed that a separate tank for ETF bottoms was preferred because of improved efficiency of operations in Sold Waste Facilities. An additional tank would allow Solid Waste to reduce the frequency of intermittent operations in $\mathrm{Z}$ Area. Accordingly, Intermediate List idea $\mathrm{IL}-21$ was selected as the most favorable idea from this group of ideas that handle ETF bottoms. Five groups of Strategies from the remaining fifteen Strategies are shown in Table 9-7 that differ only in how the ETF Bottoms stream is managed. 
Table 9-7: Down-Selection for Managing ETF Bottoms

\begin{tabular}{|l|c|c|c|}
\hline $\begin{array}{c}\text { Waste Stream or } \\
\text { Issue to Manage }\end{array}$ & $\begin{array}{c}\text { Strategy } \\
\text { Rank }\end{array}$ & $\begin{array}{c}\text { Strategy } \\
\text { No. }\end{array}$ & $\begin{array}{c}\text { Intermediate List } \\
\text { Ideas Used }\end{array}$ \\
\hline ETF Bottoms & 2 & S-104 & $10,17,18,1$ \\
\hline ETF Bottoms & 3 & $S-105$ & $10,17,21,1$ \\
\hline ETF Bottoms & 4 & $S-107$ & $10,17,69,1$ \\
\hline ETF Bottoms & 14 & $S-106$ & $10,17,72,1$ \\
\hline & & & \\
\hline ETF Bottoms & 5 & $S-13$ & $10,17,22,11,18$ \\
\hline ETF Bottoms & 7 & $S-17$ & $10,17,22,11,21$ \\
\hline ETF Bottoms & 8 & $S-25$ & $10,17,22,11,69$ \\
\hline & & & \\
\hline ETF Bottoms & 6 & $S-59$ & $10,17,22,16,18$ \\
\hline ETF Bottoms & 10 & $S-60$ & $10,17,22,16,21$ \\
\hline ETF Bottoms & 12 & $S-62$ & $10,17,22,16,69$ \\
\hline & & & \\
\hline ETF Bottoms & 11 & $S-143$ & $10,22,21,11,1$ \\
\hline ETF Bottoms & 13 & $S-151$ & $10,22,69,11,1$ \\
\hline & & & \\
\hline ETF Bottoms & 15 & $S-156$ & $10,22,21,16,1$ \\
\hline ETF Bottoms & 17 & $S-158$ & $10,22,69,16,1$ \\
\hline
\end{tabular}

Nine Strategies (S-104, S-107, S-106, S-13, S-25, S-59, S-62, S-151 and S-158) containing Intermediate List ideas $\mathbb{I L}-18, \mathbb{L}-69$ or $\mathrm{IL}-72$ were eliminated, reducing the list of Strategies to six.

\subsubsection{Eliminating the Use of Small Tanks for Emergency Space}

The six remaining Strategies shown in Table 9-8 were then examined for the handling of Emergency Space. Of the six remaining Strategies, four would reduce the $2600 \mathrm{~K}$-gal of Emergency Space now specified by operations to $1300 \mathrm{~K}$-gal specified in the Authorization Basis for the Tank Farm. Two contain Intermediate List idea IL-16, which proposes to construct 42 smaller tanks to provide emergency space, thus eliminating the need to reduce Emergency Space. One of the Strategies (S-143) does not rely on any changes to the Emergency Space to provide the needed space.

Table 9-8: Emergency Space Down-Selection

\begin{tabular}{|l|c|c|c|}
\hline $\begin{array}{c}\text { Waste Stream or } \\
\text { Issue to Manage }\end{array}$ & $\begin{array}{c}\text { Strategy } \\
\text { Rank }\end{array}$ & $\begin{array}{c}\text { Strategy } \\
\text { No. }\end{array}$ & $\begin{array}{c}\text { Intermediate List } \\
\text { Ideas Used }\end{array}$ \\
\hline Emergency Space & 1 & S-101 & $10,17,22,1$ \\
\hline Emergency Space & 3 & S-105 & $10,17,21,1$ \\
\hline Emergency Space & 7 & S-17 & $10,17,22,11,21$ \\
\hline Emergency Space & 10 & S-60 & $10,17,22,16,21$ \\
\hline Emergency Space & 11 & S-143 & $10,22,21,11,1$ \\
\hline Emergency Space & 15 & S-158 & $10,22,21,16,1$ \\
\hline
\end{tabular}


Upon closer examination, neither of the Strategies containing $\mathrm{IL}-16$ yielded a logical solution to obtain the needed space. Strategy S-10 proposes to construct 42 small tanks for use as Emergency space while simultaneously reducing available Emergency Space to the AB Limit of $1300 \mathrm{~K}$-gal. Constructing tanks for Emergency Space while also reducing the Emergency Space is an inconsistent combination of ideas. Therefore, the SM Team rejected this Strategy. Strategy S158 would construct 4 new HLW storage tanks (IL-1) and 42 smaller tanks (IL16) under separate projects. Obviously, a simpler approach would be to increase the number of new HLW tanks to 5 to provide additional Emergency Space, since a single large tank designated for Emergency Space would be easier to monitor and maintain than 42 small tanks. The SM Team also rejected this Strategy.

\subsubsection{Short List of Strategies}

Four Strategies remained for the Short List after eliminating the Strategies that either did not contain a preferred idea from the groups of ideas that were functionally similar or was based on an illogical combination of ideas. The four remaining Strategies are shown in Table 9-9.

Table 9-9: Strategies Remaining for the Short List

\begin{tabular}{|c|c|c|}
\hline $\begin{array}{l}\text { Rank } \\
\text { Order }\end{array}$ & $\begin{array}{l}\text { Strategy } \\
\text { No. }\end{array}$ & $\begin{array}{l}\text { Ideas included in Strategy from } \\
\text { the Intermediate List of Ideas }\end{array}$ \\
\hline 1 & $S-101$ & $\begin{array}{l}\text { - } \text { Evaporate backlog waste (IL-10) } \\
\text { - } \quad \text { Reduce Emergency Space to 1,300 K-gals (IL-17) } \\
\text { - } \quad \text { Recover and reuse Tank } 49 \text { (IL-22) } \\
\text { - Construct } 4 \text { New HLW Tanks (IL-1) } \\
\end{array}$ \\
\hline 3 & S-105 & $\begin{array}{l}\text { Evaporate backlog waste (IL-10) } \\
\text { - Reduce Emergency Space to } 1,300 \mathrm{~K} \text {-gals (IL-17) } \\
\text { Return Tank } 50 \text { to HLW Service - Construct new tank for storage of } \\
\text { ETF Bottoms to increase efficiency of Z Area (IL-21) } \\
\text { - Construct } 4 \text { New HLW Tanks (IIL-1) }\end{array}$ \\
\hline 7 & S-17 & $\begin{array}{l}\text { Evaporate backlog waste (IL-10) } \\
\text { - Reduce Emergency Space to } 1,300 \mathrm{~K} \text {-gals (IL-17) } \\
\text { - Recover and reuse Tank } 49 \text { (IL-22) } \\
\text { - Eliminate DWPF recycle to HLW Tank Farm by acid evaporation of } \\
\text { DWPF recycle in Salt Cell (IL-11) } \\
\text { Return Tank } 50 \text { to HLW Service - Construct new tank for storage of } \\
\text { ETF Bottoms to increase efficiency of Z Area (IL-21) }\end{array}$ \\
\hline 11 & $S-143$ & $\begin{array}{l}\text { Evaporate backlog waste (IL-10) } \\
\text { - Recover and reuse Tank } 49 \text { (IL-22) } \\
\text { - Return Tank } 50 \text { to HLW Service - Construct new tank for storage of } \\
\text { ETF Bottoms to increase efficiency of } Z \text { Area (IL-21) } \\
\text { - Eliminate DWPF recycle to HLW Tank Farm by acid evaporation of } \\
\text { DWPF recycle in Salt Cell (IL-11) } \\
\text { - Construct } 4 \text { New HLW Tanks (IL-1) }\end{array}$ \\
\hline
\end{tabular}


After narrowing the number of Strategies to the Short List of four Strategies, the SM Team reviewed the four remaining Strategies with Stakeholders to obtain input on any concerns or advantages for any of these Strategies. Based on Stakeholder input and team expertise, the Strategy described below was selected.

\subsubsection{Down-Selection of Strategy}

The logic used to reach the overall Strategy was as follows:

- All four Strategies incorporated the need to evaporate waste and recover the space potential of that idea ( $\mathbb{L}-10)$. This idea is common to all of the Strategies and does not provide a means to discriminate between Strategies.

- Recovery and reuse of two HLW Tanks now associated with other programs is straightforward and relatively inexpensive. Recovery of Tanks 49 and 50 are associated with IL-22 and IL-21, respectively. Two Strategies (S-17 and $S$-143) used both of these ideas. The top-ranked Strategy (S-101) reduced emergency space rather than recovering Tank 50 for use while the next Strategy on the Short List (S-105) reduced Emergency Space instead of recovering Tank 49. Because of operational complexities identified by Stakeholders, reducing emergency space early in the study period, which these latter two Strategies require, is much less desirable than recovery of either Tank 49 or Tank 50 .

- Three of the four Strategies on the Short List reduce the amount of Emergency Space maintained in the Tank Farm to the minimum volume specified in the Authorization Basis. The SM Team and Stakeholders agreed that this was acceptable, but only in the latter years of the study period (beyond FY2006) after other ideas are implemented that will significantly reduce the volume of influents into the Tank Farms. As noted above, two of the Strategies (S-101 and S-105) require a reduction in Emergency Space prior to FY2005. Strategy S-17 can tolerate a delay in the reduction of Emergency Space until FY2007 (or beyond) while Strategy S-143 does not reduce Emergency Space during the study period.

- Two of the four Strategies (S-17 and S-143) divert DWPF recycle from the HLW Tank Farm. The DWPF recycle would be evaporated in a new evaporator installed in the Salt Cell of the DWPF. Overheads would be sent to the ETF. Evaporator bottoms would be combined with incoming waste (sludge slurry) and frit for processing through the melter. Aqueous waste generated in the DWPF would no longer require space in the HLW Tank Farm. Not only does this idea increase available space in the Tank Farm, it also has a number of significant benefits unrelated to space:

- It simplifies the operation of both the DWPF and the Tank Farm by eliminating daily transfers of DWPF recycle waste, effectively decoupling these processes. 
- It reduces the risk of DWPF shutdown. As less space is available, a shutdown of Tank Farm evaporators could force a shutdown of the DWPF.

- It reduces a suspected cause of Tank Farm evaporator problems. Recent experience suggests that DWPF sludge carryover events, which release solids into the DWPF recycle, introduce compounds into the Tank Farm that can cause hard pluggage of transfer lines and degrade Tank Farm evaporator operation.

- It simplifies the operation of the Tank Farm by eliminating the DWPF recycle, the largest source of waste coming into the Tank Farm. Although the DWPF recycle is mostly water and occupies a relatively small volume after evaporation, it places a large load on the Tank Farm capacity to move and evaporate waste.

- Three of the Strategies (S101, S-105 and S-143) incorporate constructing four new waste tanks (IL-1). This idea has a major unfavorable impact on cash flow (financial penalty) in the early years of the study period. Construction of new tanks would extend the time required to complete the Site mission to empty and close all HLW tanks, requiring renegotiation of the Site Treatment Plan with the State of South Carolina and possibly the Federal Facility Compliance Agreement with the State and the Environmental Protection Agency.

A project to build new waste tanks should only be initiated if the project for the Alternative Salt Process is delayed. The proposed schedule used for evaluating this idea (IL-1) is based on an accelerated schedule that completes tank construction by FY2007. This schedule would be difficult to achieve, if work on this capital project does not begin in FY2000. The SM Team and Stakeholders consider a project for the construction of new HLW tanks to be a part of a longerterm Strategy, and it should only be started if additional space is required beyond 2009.

Based on the above logic, the SM Team determined that Strategy S-17 was the preferred combination of ideas even though it was ranked number 7 in the top eighteen Strategies and third in the Short List. This Strategy recovers tank space by evaporation, recovers and uses tank space in Tanks 49 and 50, diverts the DWPF recycle from the Tank Farm, and allows for the flexibility to delay the reduction of Emergency Space until late in the study period.

\subsubsection{Review of Overall Strategy with WSRC Stakeholders}

The overal Strategy and a proposed implementation schedule was presented to Stakeholders from DWPF, the HLW Tank Farm organizations and the HLWMD Program Board. A draft report was provided for a review and comment period following this presentation. Comments have been addressed in this report. 


\subsubsection{Impact Beyond FY2009 - Decision to Build New Waste Tanks}

An initiative to build new waste tanks would not change the SM Team's Overall Strategy. The construction of new tanks would added to the other actions proposed if the Alternative Salt Processing Facility to process salt solution is not operational by FY2010.

The SM Team Charter ${ }^{2}$ required the selection of a single Strategy for safely managing HLW until at least through FY2009. The schedule for the start-up of the Alternative Salt Process should be closely monitored to assure the new facility is operational early in FY2010. If significant delays in the startup are expected beyond FY2010, then construction of new HLW Tanks (IL-1) could be required to assure adequate space is available beyond FY2009.

A decision on the schedule for the Alternative Salt Process Facility must be made within FY2000. If the schedule for this new facility cannot meet the date assumed for this study (operational by the end of FY2009), a Project to build new HLW tanks must be initiated in FY2001 to assure the new tanks are ready for use beyond FY2009. 


\subsection{Glossary}

1. Assumption:

2. Available Space (Gallons):

3. Available Space Baseline (ASB):

4. Basis:

5. Concentrated Liquor:

6. Consequence of Occurrence:

7. Constraint:
Not a validated piece of information, but sometimes required to facilitate other input or output activities. All assumptions carry risk and should be evaluated for consequences during the risk analysis stage.

That portion of HLW Freeboard that can be used for receipts of incoming waste. Available space is calculated by subtracting emergency space and working space from Freeboard.

The set of assumptions used by the SM Team to define the Available Space if no actions are taken to increase Available Space. Using these assumptions, HLW Program Management determined the required increase in available space for each year from 2000 to 2009. Ideas and Strategies are measured versus this Baseline. The Baseline includes project missions for the tank farms and the assumptions that current tank farm operating practices and programs will continue. It does not include proposed changes to operating practices or changes in projected tank use.

The rationale, declaration, and/or starting point for a decision, method, and/or analysis.

Salt solution that has been evaporated to a specific gravity of 1.45 or greater.

The impact(s) realized as a result of a risk occurring.

Limits or thresholds that exist for a system, boundary, external interface, and/or component which have been established by programs, policy, standards, the physical laws of nature, or an empirical definition that must be addressed and compiled for all solutions/alternatives. Example: Recycle Flow may never exceed 100 gpm or have a rate change greater than $10 \mathrm{gpm} / \mathrm{hr}$. 
8. Demonstrated

(Proven) Technology: Technology which is commercially available and/or has been used in the nuclear industry.

9. Emergency Space: Minimum volume of space that must be maintained in Type III/IIIA tanks at all times, in the unlikely event of a tank leak. Currently the limit is set at 370 " (1.3 million gallons), the TSR limit.

10. Freeboard:

Space available for HLW storage that is not occupied. For example, the freeboard for a tank is the volume available at its operating limit minus the volume of waste in the tank.

11. Function:

A qualitative statement of what a solution must do using a verb/noun format, e.g., "Pump water". A function must have at least one requirement.

12. Hold:

A piece of information with some, but not complete, validation or traceability. There is a risk associated with "Holds" and they should be evaluated for consequences during the risk analysis stage.

13. Idea:

A concept, if implemented, which would increase the amount of available space.

14. Increase in Available Space (Gallons):

The increase in Available Space that results from implementing an idea or strategy relative to the Available Space Baseline.

15. Initial List:

The list of ideas which passed the screening criteria.

16. Intermediate List:

The list of ideas resulting in the highest Ten-Year Increase in Available Space (TIAS).

17. ISMS:

Integrated Safety Management System (ISMS) is the methodology, applicable to the design, construction, operations, transition and D\&D phases of a facility lifetime, which implements the DOE environmental, health, and safety programs as a single initiative through the application of the following five steps:

i. Define the work and how it is to be accomplished;

ii. Analyze the hazards entailed in performing the work; 
iii. Identify the controls necessary to perform the work safely and include them in design, construction, operational, transitional, and D\&D procedures;

iv. Perform the work as planned, using adequately trained personnel; and

v. Evaluate how well the system worked, and feed back the evaluation results to reinforce and improve the process.

18. Life Cycle Cost:

(LCC) equals acquisition costs plus ownership costs plus disposition costs, less any revenues, and less any salvage.

$[\mathrm{LCC}=\mathrm{TPC}+\mathrm{O} \& \mathrm{M}+\mathrm{D} \& \mathrm{D}-$ Salvage $]$

(DOE LCC Estimating Course PMCE01, Version

1.0/July 1997)

19. Probability of Occurrence:

20. Ranking:

21. Requirement:

22 Residual Risk Level:

23. Risk

24. Risk Acceptance:

25. Risk Handling Strategy:
The likelihood that a risk will be realized.

The chronological ordering of Intermediate List ideas based on the numerical scores (high to low) resulting from the application of weighted evaluation criteria.

A quantitative, measurable statement that specifies "how well" a function must perform, e.g., "20 gpm". Requirements can be performance, interface, design criteria, and/or other constraints placed on a function.

The significance of the risk remaining after credit is taken for proposed risk handling Strategies.

An issue that may cause an uncertainty.

A handling strategy that accepts the risk "as is". This type of strategy does not attempt to reduce the risk level. Low and some moderate level risks are examples of the types of risks that are normally subject to being accepted.

An approach which, if implemented, would eliminate or at least reduce the consequence of a risk occurring. Handling Strategies can be grouped into the following five categories:

- Risk Acceptance

- Risk Mitigation 
26. Risk Level:

27. Risk Mitigation:

28. Risk Prevention:

29. Risk Reduction:

30. Risk Transference:

32. Stakeholders:

33. Storage Space:

34. Strategy:

\section{Subject Matter Experts:}

\section{- Risk Reduction \\ - Risk Transference \\ - Risk Acceptance}

The significance of the identified risk based on probability and consequence considerations.

A handling strategy that mitigates the consequence of a risk. This type of strategy essentially drives the consequences of a risk to zero, eliminating the risk.

A handling strategy that prevents the risk from occurring (avoidance). This type of strategy essentially drives the probability of the risk occurring to zero, eliminating the risk.

A handling strategy that reduces risk, but does NOT eliminate it. This type of strategy reduces the probability and/or the consequences of a risk, but eliminates neither. The risk remains, but at a reduced level.

A handling strategy that transfers the risk to a new owner (e.g., different project). The new owner must accept the risk before it can be transferred.

31. Sensitivity Analysis: Determining if there are large changes in the Intermediate List rankings based on small changes $( \pm 10 \%)$ in the evaluation criteria weights or UFV.

Individuals or organizations potentially impacted by the recommended strategy(s).

Any container or location where HLW may be placed until it can be safely processed for final disposal.

An idea or group of ideas from the Intermediate List which, if implemented, would increase the amount of available space in the time frame needed to satisfy the Strategy Input Package (SIP).

Individuals recognized by the SM Team as experts in a particular field(s). 
36. Ten-Year Increase In Available Space (TIAS):

The increase in Available Space (in gallons of salt) through the year 2009 relative to Available Space Baseline. This

- TIAS measures the total impact of an idea or Strategy over the period 1999 to 2009.

37. Total HLW Freeboard: The total freeboard in the SRS High-Level Waste System in tanks that are available for receipt of new wastes.

38. TBD:

"To Be Determined" this is simply an information "placeholder". NOT knowing something at the present time does not impede near-term development of design or Strategy input or output. There is risk associated with TBD's and should be evaluated for consequences during the risk analysis stage.

39. Uncertainty: Potential variance in the cost or schedule of an alternative.

40. Utility Function (UF): A statement describing a specific characteristic of an attribute.

41. Utility Function Value (UFV):

The numerical value assigned to a specific UF. The most desirable UF is assigned a value of 100 and the least desirable is assigned a value of zero.

42. Weighted Evaluation Criteria:

Key attributes (and their relative importance to each other) considered in the evaluation of Intermediate List ideas. Attributes have the following characteristics:

1. Independence from each other.

2. Address all necessary and sufficient functions and requirements for high risk issues identified in previous risk assessments.

3. Universally understood by evaluators.

4. Differentiate meaningfully among alternatives without bias.

5. Be quantifiable (e.g., analysis, subject matter expertise, Team judgement, etc.) 
43. Working Inventory: The combination of working space and available space.

44. Working Space: Volume reserved for waste receipts and evaporator operations. Currently $200 \mathrm{~K}$ gallons per evaporator system and $100 \mathrm{~K}$ gallons per area for waste receipts. Presently this is $500 \mathrm{~K}$ gallons for $\mathrm{H}$-Area, and $300 \mathrm{~K}$ gallons for F-Area.

45. Uncertainty:

Potential variance in cost or schedule of an idea or Strategy. 


\subsection{Acronyms}

\begin{tabular}{|c|c|}
\hline AGNS & Allied General Nuclear Service \\
\hline ASB & Available Space Baseline \\
\hline CIF & Consolidated Incineration Facility \\
\hline CST & Crystalline Silicotitanate \\
\hline DOE-SR & Department of Energy-Savannah River \\
\hline DWPF & Defense Waste Processing Facility \\
\hline EIS & Environmental Impact Statement \\
\hline EM & Environmental Management \\
\hline EPA & Environmental Protection Agency \\
\hline ESP & Extended Sludge Processing \\
\hline ETF & Effluent Treatment Facility \\
\hline FFA & Federal Facilities Agreement \\
\hline HLW & High Level Waste \\
\hline HLWPE & High Level Waste Process Engineering \\
\hline IAS & Increase in Available Space \\
\hline ISMS & Integrated Safety Management System \\
\hline ITP & In-Tank Precipitation \\
\hline IWWP & Industrial Waste Water Permit \\
\hline LAW & Low Activity Waste \\
\hline LCAM & Life Cycle Asset Management \\
\hline $\mathrm{LCC}$ & Life Cycle Cost \\
\hline LDR & Land Disposal Restrictions \\
\hline MAUA & Multi-Attribute Utility Analysis \\
\hline NEPA & National Environmental Protection Agency \\
\hline $\mathrm{NRC}$ & Nuclear Regulator Commission \\
\hline OSR & Operational Safety Requirement \\
\hline PA & Performance Assessment \\
\hline $\mathrm{R} \& \mathrm{D}$ & Research \& Development \\
\hline
\end{tabular}


Control

SE

Systems Engineering

SEMP

Systems Engineering Management Plan

SIP

Strategy Input Package

SM Team

Space Management Team

SMEs

Subject Matter Experts

SRS

Savannah River Site

STP

Site Treatment Plant

TCLP

Toxicity Characteristic Leach Procedure

TIAS

Ten-Year-Increase in Available Space

TPB

Small Tank Tetraphenylborate Precipitation

TSR

Tank Space Requirement

UF

Utility Function

UFV

Utility Function Value

WAC

Waste Acceptance Criteria

WCP

Waste Compliance Plan

WCS

Waste Characterization System

WDE

Waste Disposal Engineering

WPT(E)

Waste Pre-Treatment (Engineering)

WSMS

Westinghouse Safety Management Solutions

WSRC

Westinghouse Savannah River Company 


\subsection{References}

1. HLW-OVP-98-0037, “High Level Waste System Plan, Revision 9.

2. HLW-SDT-99-0022, "Charter for the SRS HL Tanks Space Management Team".

3. WSRC-RP-99-00003, "System Engineering Management Plan (SEMP)"

4. HLW-PMD-99-0027, "Available Space Baseline for HLW Space Management Team Initiative, Revision 2".

5. HLW-SDT-99-0036, "Phase I Strategy Input Package”.

6. HLW-SDT-99-0189, “Desktop Procedures Compendium”.

7. HLW-SDT-99-0055, "Results Report on The Identification of Concepts to Manage HLW Storage Space".

8. HLW-SDT-99-0063, "Results Report on the Determination of Initial List Ideas".

9. HLW-SDT-99-0066, "Results Report on the Intermediate List of Ideas based on Space Gain Contributions.

10. HLW-SDT-99-0167, "Results of the HLW Tank Space Management Team Criteria Selection, weighting, Utility Functions and Values, for Strategy Evaluations".

11. SRT-SCS-99-050, "Sensitivity analysis for HLW SM Team".

12. HLW-SDT-99-0147, Results Report on the Risk analysis of Intermediate List Ideas

13. HLW-SDT-99-0203, "Life Cycle Cost Estimate of Intermediate List Ideas".

14. HLW-SDT-99-0233, “Macro/Spreadsheet for Strategy Development”

15. HLW-DEN-99-0207, "Results Report of the Software Verification for Spreadsheets and Macros Implementing the SM Team Strategy Evaluation".

16. HLW-SDT-99-0220, "Results Report on the Development of Tank Space Management Strategies".

17. HLW-SDT-99-0128, "Results Report on the Application of Weighted Evaluation Criteria".

18. WSRC-RP-99-00005, "HLW Tank Space Management Team Final Report".

19. HLW-SDT-99-0008, "HLW System Plan (U), Rev. 10". 